\title{
Stream or Discharge: Using the Hydrosocial Cycle to Explore the Meanings of the Waimapihi Stream in Te Whanganui-a-Tara- Wellington, Aotearoa-New Zealand.
}
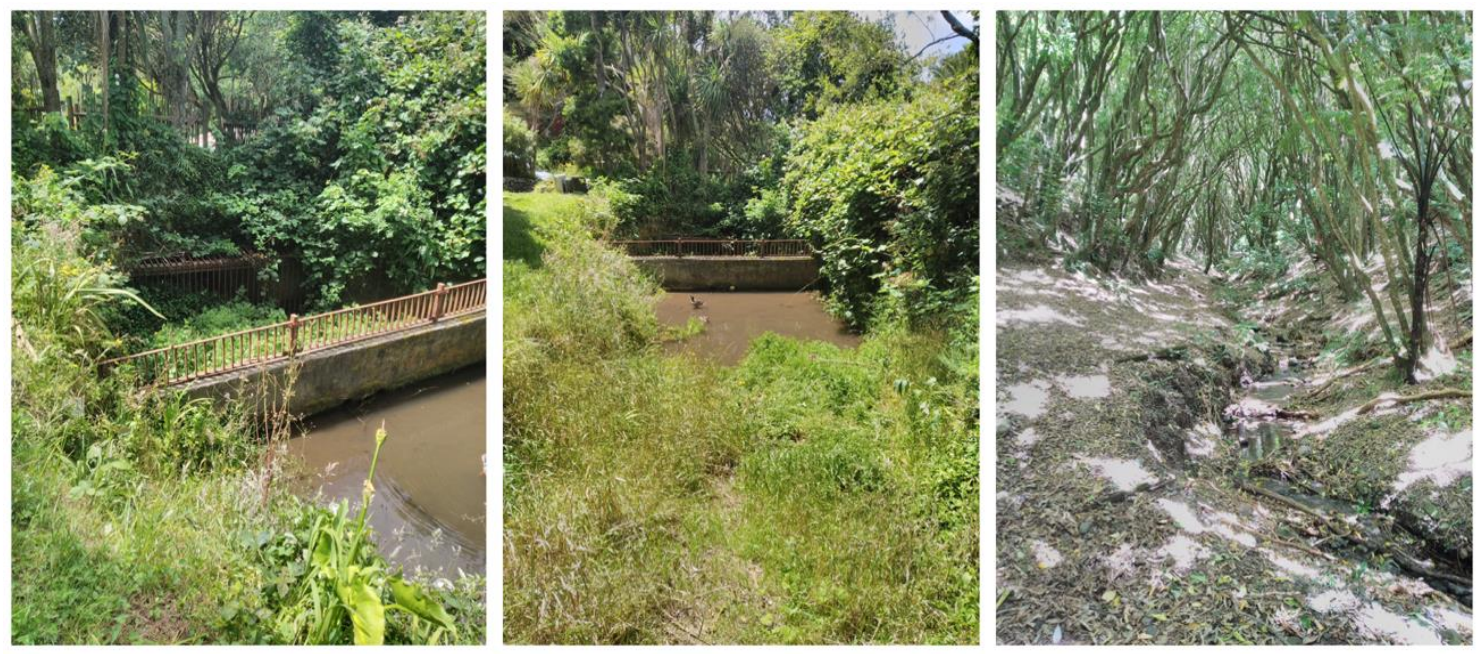

Sylvie McLean

A thesis submitted to Te Herenga Waka Victoria University of Wellington in partial fulfilment of requirements for the degree of Master of Environmental Studies

Te Kura Tātai Aro Whenua School of Geography, Environment and Earth Sciences

Te Herenga Waka Victoria University of Wellington

March 2020 
Images on front cover are of the headwaters of the Waimapihi Stream

All images are taken by me unless indicated otherwise. 


\section{Abstract:}

Aotearoa-New Zealand's urban streams are complex and diverse but have been degraded and neglected for years. For the most part, hegemonic management regimes are technocratic, separating streams into discrete parts, and thus have failed to improve or maintain the state of urban streams. The hydrosocial cycle is a way of exploring streams that takes account of whole systems, flows of water, more than humans, infrastructure and technology, and the social structures and institutions that make up water. The framework has been used to study the impacts of urbanisation on water around the world, including issues around stormwater, wastewater, water supply, and rivers, but it has rarely been used to study buried urban streams. This research uses a case study of the Waimapihi Stream in Te Whanganui-a-Tara-Wellington, Aotearoa-New Zealand to explore how the hydrosocial cycle could be used to understand urban streams. A hydrosocial approach, alongside a more-than-human methodology, demonstrated the varying meanings of the stream, including those of the different phases along its length. Connections to the buried section of the Waimapihi arose through the presence of fish, physical markers, and stories, but there was dissatisfaction with the extent of these. As a result, alternative methods of connection such as windows to the stream and areas of it to be daylighted were explored. A hydrosocial approach enabled an examination of meanings and values of the Waimapihi Stream; to encourage critical analysis of how streams are defined and how they are managed. This demonstrated that the hydrosocial cycle provides a valuable framework for understanding urban streams, as it encompasses the various components that make up urban streams and is flexible enough to explore the diversity between and within them.

Key words: Hydrosocial cycle, more-than-human, stormwater, wastewater, urban streams, Te Whanganui-a-Tara-Wellington, Aotearoa-New Zealand. 


\section{Acknowledgements:}

Thank you to tangata whenua and mana whenua for having me on the land and in the Waimapihi Stream. I acknowledge tino rangatiratanga and recognise that my fulfilment of a master's degree occurred on land taken violently.

Thank you to the Waimapihi for having me around for this year, I hope we can remain friends. Thank you to the participants for your wonderful insights.

Thank you to my supervisors Amanda Thomas and Mike Joy for your incredible wisdom.

Thank you to Aaron, HanLing, Mel, Amelia, Sarah, Jojo, Hannah, Hayden, and Victor for the companionship and for indulging my fantasy of being the quiz master for the Stuff quiz every day at $3 \mathrm{pm}$ !

Thank you to proofreader extraordinaire Asia for blessing my thesis with oxford commas and semi-colons! Thank you to concise writer Dad for cutting my word count down substantially! Thank you to Mum for feeding me delicious food and keeping me calm in moments stress! Thank you to Molly for pointing out the typo on my front cover and saving me from embarrassment!

Thank you to my friends for enduring me talking about streams incessantly all year. 


\section{Contents:}

Abstract:_......................................................................................................................

Acknowledgements: .............................................................................................................

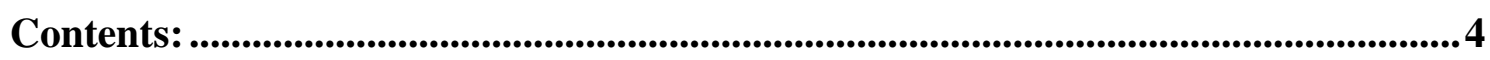

Abbreviations: ...................................................................................................................................

List of Figures: .............................................................................................................................

List of Tables: .....................................................................................................................9

Chapter One: Introduction .........................................................................................10

1.1. What Lies Hidden Beneath the Streets of Te Whanganui-a-Tara-Wellington?... 10

1.2. Theoretical Grounding and Rationale: The Hydrosocial Cycle Another Way of

Thinking about Urban Streams .............................................................................. 12

1.3. The Gap, Research Questions and Aims ............................................................ 17

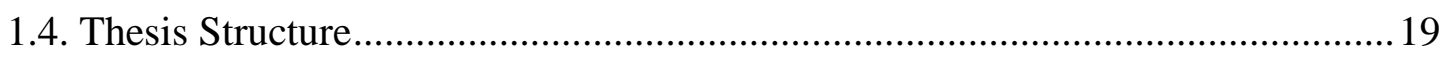

Chapter Two: Context and Past of the Waimapihi Stream ...........................................20

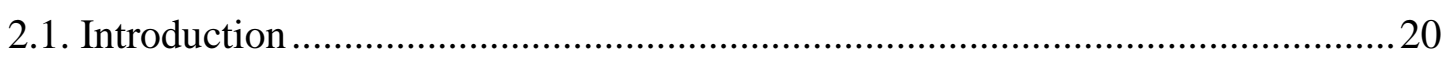

2.2. Physical Geography of Central Te Whanganui-a-Tara-Wellington......................20

2.3. Māori Migrations and Settlement ……………………………………….....2

2.4. Impacts of Colonisation and Urbanisation on the Physical and Social Landscape of Te Whanganui-a-Tara-Wellington........................................................................ 25

2.5. The Burial of the Waimapihi Stream ………………………………………..... 27

2.6. Introducing the Waimapihi in its Current State ……………………………....... 28

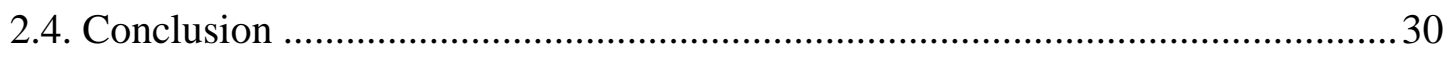

Chapter Three: Methodology and Theoretical Underpinnings.....................................31

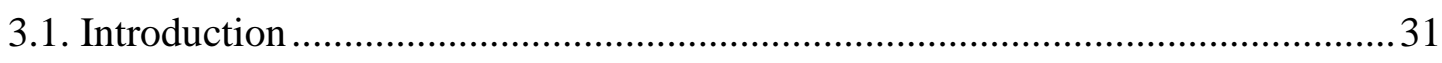

3.2. Theoretical Framework and Epistemology …………………………………........ 31 
3.4. My Struggle to Figure out a Methodological Approach Appropriate to the Context of the Research 38

3.4.1. Initial Stumble into a Decolonising Methodology ….................................... 39

3.4.2. Deciding on a More-Than-Human Methodology with Caveats.....................4 42

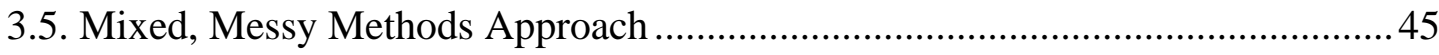

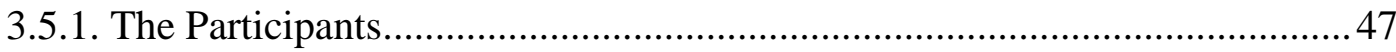

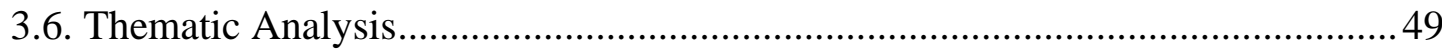

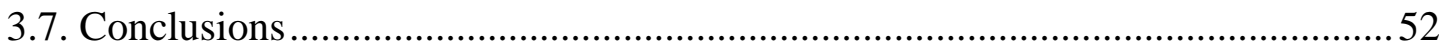

Chapter Four: Spatial and Temporal Phases of the Waimapihi .................................53

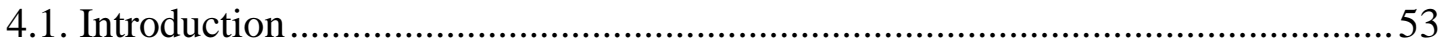

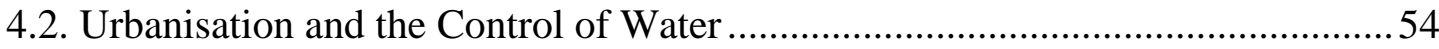

4.3. The Waimapihi Stream in the Waimapihi Reserve...........................................58

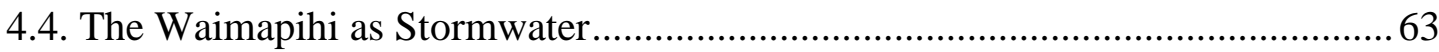

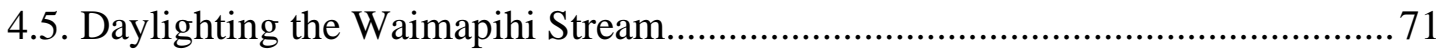

4.6. The RMA (1991) along the Phases of the Waimapihi ........................................ 78

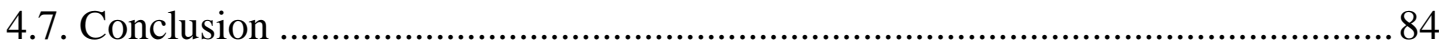

Chapter Five: Fish in the Waimapihi Stream ...........................................................8

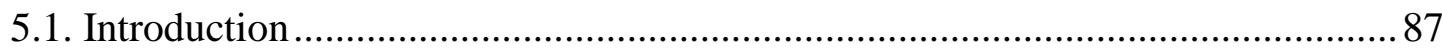

5.2. Fish in the Headwaters at Waimapihi Reserve .................................................8 89

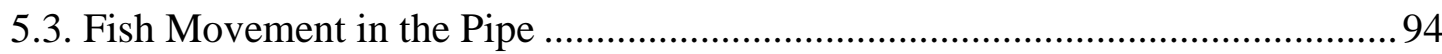

5.4. Enhancing Fish Passage in the Waimapihi Stream ........................................ 101

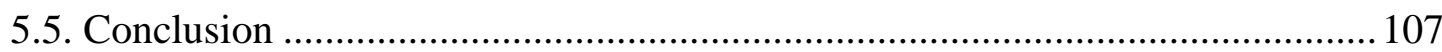

Chapter Six: People's Connection to the Waimapihi Stream..................................109

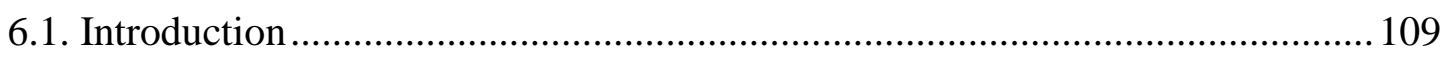

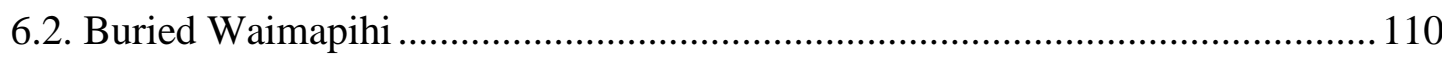


6.3. Alternative Ways People Have Tried To Connect to the Buried Waimapihi .... 114

6.4. Raising Awareness and Engaging with the Waimapihi Stream ........................ 125

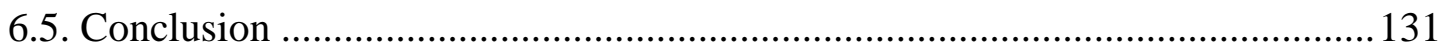

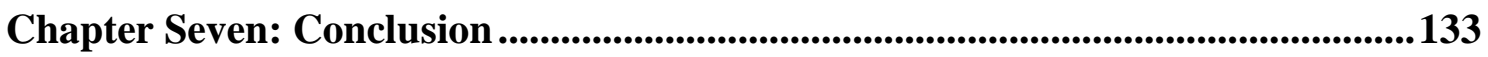

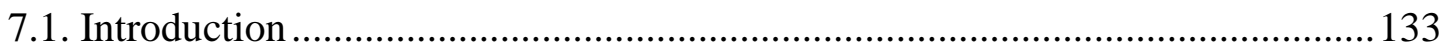

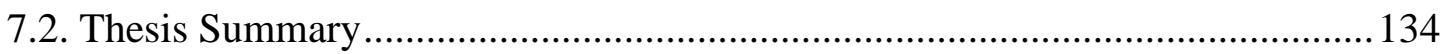

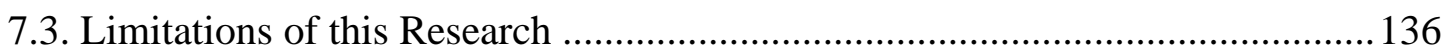

7.4. Implications and Further Research............................................................... 137

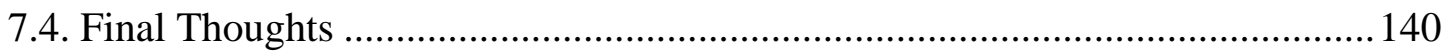

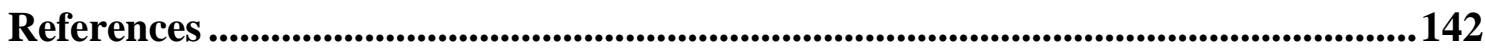

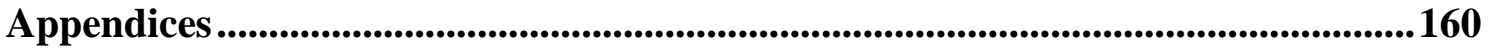

Appendix A: Human Ethics Application Approval ................................................ 161

Appendix B: Animal Ethics Application Approval .................................................162

Appendix C: Information Sheet for Interviewees ................................................. 163

Appendix D: Consent Form for Interviewees ....................................................... 167

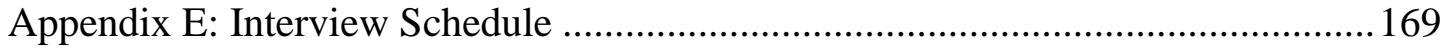




\section{Abbreviations:}

GWRC: Greater Wellington Regional Council

MfE: Ministry for the Environment

NES: National Environmental Standards for Sources of Human Drinking Water

NPS-FM: National Policy Statement for Freshwater Management (2014 (amended 2017))

NZC: New Zealand Company

NZCPS: New Zealand Coastal Policy Statement (2010)

RMA: Resource Management Act (1991)

USGS: United States Geological Survey

WCC: Wellington City Council

WW: Wellington Water 


\section{List of Figures:}

Figure 1: Map of six buried streams in central Te Whanganui-a-Tara-Wellington.........11

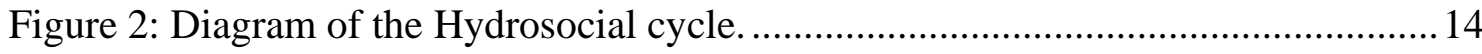

Figure 3: Taranaki Whānui ki Te Upoko o Te Ika rohe, with Te Aro Pā ........................24

Figure 4: Map of Waimapihi Stream with piped section and open sections..................29

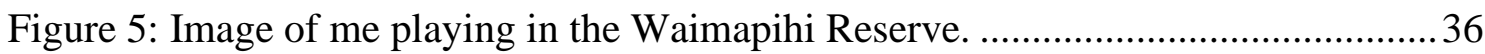

Figure 6: Analysis process to determine the overall themes.........................................51

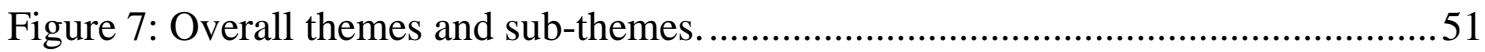

Figure 8: Images of the headwaters of the Waimapihi Stream, in Waimapihi Reserve 59

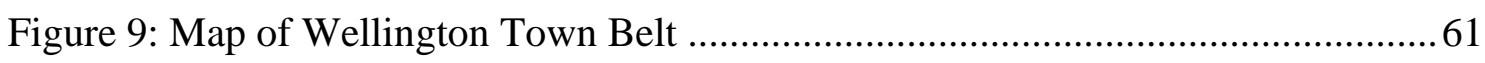

Figure 10: Path of the pipe of the Waimapihi and stormwater pipes.............................64

Figure 11: Image of sign at Waimapihi outlet warning against swimming .................. 70

Figure 12: Map of open waterways, stormwater pipes and wastewater pipes ............... 70

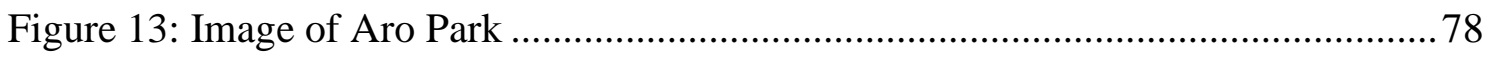

Figure 14: Diagram showing the 'type' of water, government jurisdiction and laws and

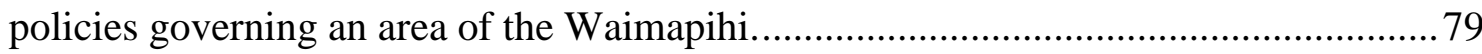

Figure 15: Images of two tyres seen in headwaters of Waimapihi. ...............................90

Figure 16: Image of the headwaters of the Waimapihi Stream, in Waimapihi Reserve. 91

Figure 17: Images of banded kokopu and kōura taken during spotlighting...................92

Figure 18: Elevation profile of the Waimapihi pipe ….............................................. 97

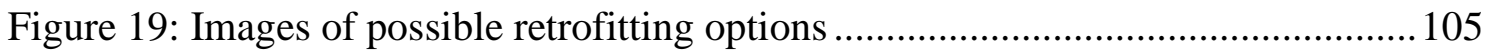

Figure 20: Map showing where markers are along the path of the piped section.......... 115

Figure 21: Image of mosaic at Aro Valley Preschool................................................ 116

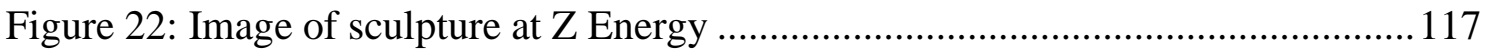

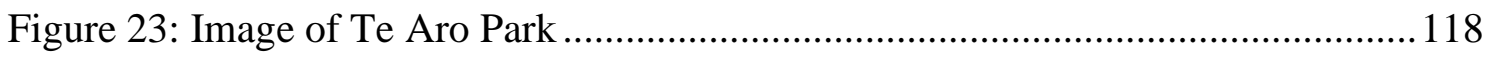


Figure 24: Images of pools at Te Aro Park.

Figure 25: Image of list of streams in Te Whanganui-a-Tara-Wellington on handmade tiles in Te Aro Park, on right the Waimapihi can be seen in the list.

\section{List of Tables:}

Table 1: List of participants and their relationship to the Waimapihi Stream. .49 


\section{Chapter One: Introduction}

\subsection{What Lies Hidden Beneath the Streets of Te Whanganui-a-Tara-Wellington?}

Te Whanganui-a-Tara-Wellington ${ }^{1}$ is home to many streams due to its topography of hills and valleys around a harbour. In the central city alone, there are six streams, and all have some of their length buried under the city as they flow into the Lambton Harbour (figure 1). In pre-colonial times these streams, and likely more we are unaware of, openly flowed throughout what is now the city. However, today $95 \%$ of the length of these streams are buried underground, leaving most residents in the central city unaware of their existence (Ballance, 2019). The loss of urban streams is an issue in cities all around the world. Consequently, urban dwellers are losing their connection to them, despite these streams being the foundations of the identity, structure, and functioning of many cities (Gibbs, 2014). Historically, urban streams in Aotearoa-New Zealand have been neglected, however, over the last two decades there has been an acknowledgement of the need to focus on urban freshwater (Chakravarthy, et al., 2019). Urban streams provide key ecosystems for many endangered species, are valuable greenspaces, and perform vital civic functions (Elmore and Kaushal, 2008). However, around the world knowledge of them is limited and management approaches, that tend to be technocratic, have failed to adequately protect and maintain their state (Cousins, 2017a). Therefore, changes need to be made in how we understand and value urban streams. The hydrosocial cycle is an approach that sheds light on the way different waters are constructed and the various components that produce waters (Linton and Budds, 2014). This is useful because urban

\footnotetext{
${ }^{1}$ The names of the city and country will be coupled, such as Te Whanganui-a-Tara-Wellington and Aotearoa-New Zealand, to acknowledge the long history of Māori and non-Māori interactions with the land, waters and with each other.
} 
streams tend to have open and piped sections, with the latter generally considered stormwater, which has profound impacts on management and understanding of them.

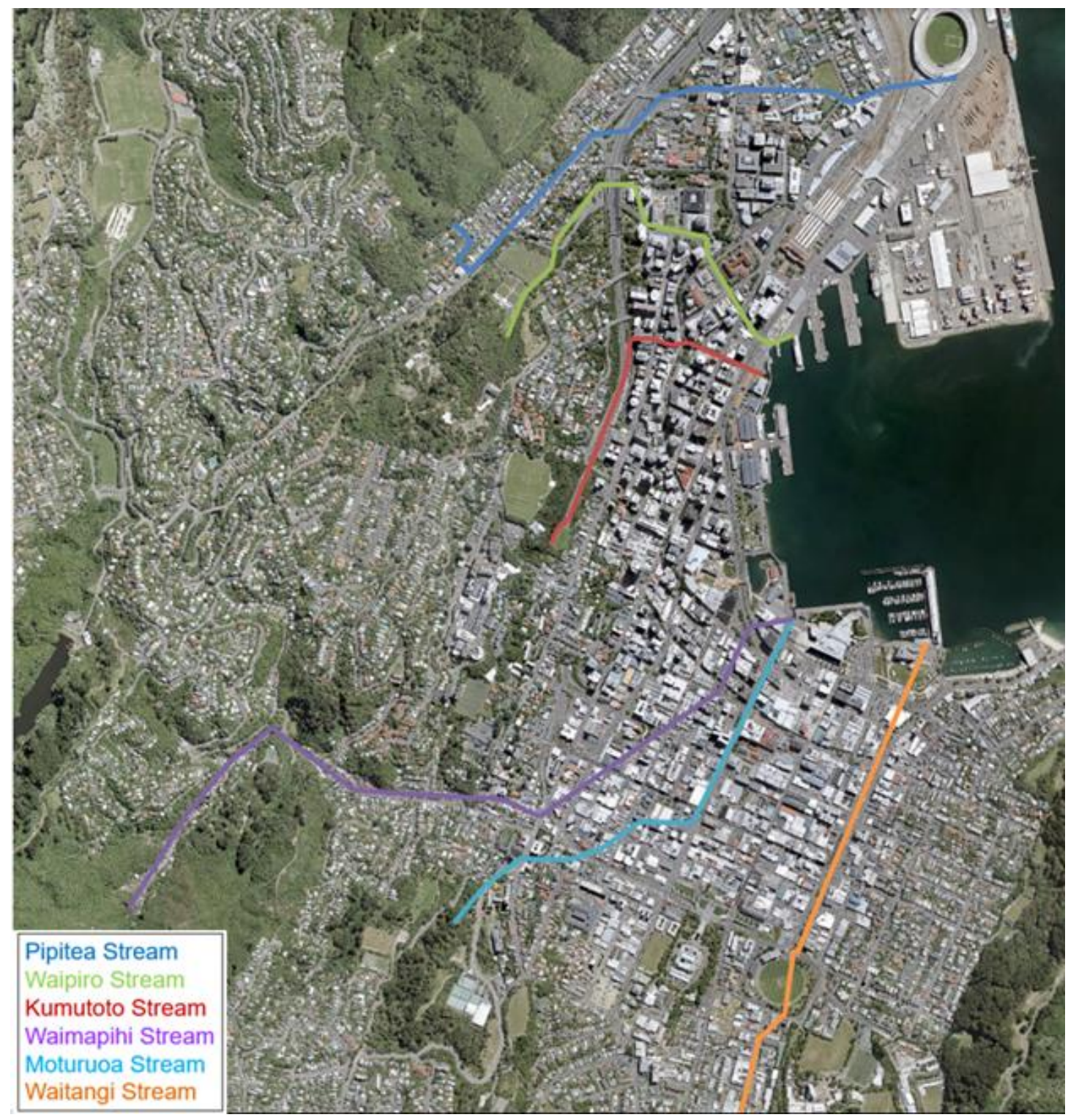

Figure 1: Map of six buried streams in central Te Whanganui-a-Tara-Wellington. Adapted from Water and Drainage-LocalMaps, by WCC, 2019, Retrieved from:

https://gis.wcc.govt.nz/LocalMaps/Viewer/?map=57fb534c2174471ca485132112088afc

This research takes a case study approach that looks at one waterway, where there are different waters evident in different parts of the stream, in order to explore the complexities and nuances of the hydrosocial cycle in place. The stream that is the focus of this study is the Waimapihi (a.k.a. Te Aro Stream) in Te Whanganui-a-Tara- 
Wellington, Aotearoa-New Zealand. This stream is of interest as it comprises an open and piped section, and flows through a reserve and under the city, which means comparisons can be made along the stream. These sections inform how people interact with, understand, and manage it, reflecting the complexity and prevailing issues around urban streams. The hydrosocial cycle incorporates the physical flow of water, the social relations that have influenced this human modification, and the infrastructure the stream flows through (Linton and Budds, 2014). The next section will explore the hydrosocial cycle to set the theoretical underpinning for this research.

\subsection{Theoretical Grounding and Rationale: The Hydrosocial Cycle, Another Way of Thinking about Urban Streams}

The hydrosocial cycle is a framework to critically analyse the political ecologies of water (Bakker, 2012). Political ecology is a field of thought that perceives the environment as political, it explores the power relations that drive the production and distribution of resources with the aim to contest the reproduction of socio-natural inequalities (Wesselink, et al., 2017). Power has two definitions: power to and power over (McGettigan, 2008). Power to is having the ability to affect things, it is the individual level enactment of power. Power over is occupying a position of dominance or power over others, therefore it is part of a social relationship. This social power can be exercised by an individual, organisation, or culture. Individual enactment of power is one individual having power over another individual; the same with organisational enactment. While cultural enactment of power is power that steers socio-cultural structures of society (McGettigan, 2008). Therefore, power relations represent power over generally at the organisational or cultural scale. 
Political ecology has been used to analyse the simultaneously political, economic, and ecological processes around water, critiquing the nature-society dualism that influences understandings about what water is and how it fits with society (Bakker, 2003). The hydrosocial cycle as a concept has been present in scholarship since the early 2000s by theorists, such as Swyngedouw, when describing the social and political dimensions of water (Linton and Budds, 2014). However, definitions and employment of the hydrosocial cycle was scattered until the seminal work by Linton and Budds (2014) that provided a clearer definition for the cycle to be: 'a socio-natural process by which water and society make and remake each other over space and time' (p. 175). The hydrosocial cycle, as a political ecology approach, asks three main questions: the ontological question of what is water? The epistemological question of how water is known? Finally, how does water internalise social relations, social power, technology, and infrastructure? These questions aim to critique the current hydrological understanding of water, to explore how water is constructed through discursive practices and alternative ways of knowing water (Linton and Budds, 2014). This section explores the three components of the hydrosocial cycle, the meanings around the cycle, and the role it has in the production of water meanings.

The hydrosocial cycle (figure 2) comprises three components: social power, structures, and institutions; technology and infrastructure; and the physical flow of $\mathrm{H}_{2} \mathrm{O}$ itself (Linton and Budds, 2014). The $\mathrm{H}_{2} \mathrm{O}$ component of the hydrosocial cycle describes the physical flow of $\mathrm{H}_{2} \mathrm{O}$ molecules in all states; gaseous, liquid, and solid. Flow is never fixed, it is transient, and this is how it perpetually destroys, creates, combines, and separates landscapes, features, and substances (Swyngedouw, 1996). This flow of $\mathrm{H}_{2} \mathrm{O}$ circulates at many scales: from bodies to cities; countries and globally (Swyngedouw, 2006). Circulation transcends human defined boundaries and defies jurisdictions. It is fluid and unpredictable, making it both a difficult force to control and a valuable one, as it has a myriad of uses (Bakker, 2012). Including material $\mathrm{H}_{2} \mathrm{O}$ into the cycle illustrates that it is not external to, and controllable by, human ingenuity, but rather can change social processes (Linton and Budds, 2014). 


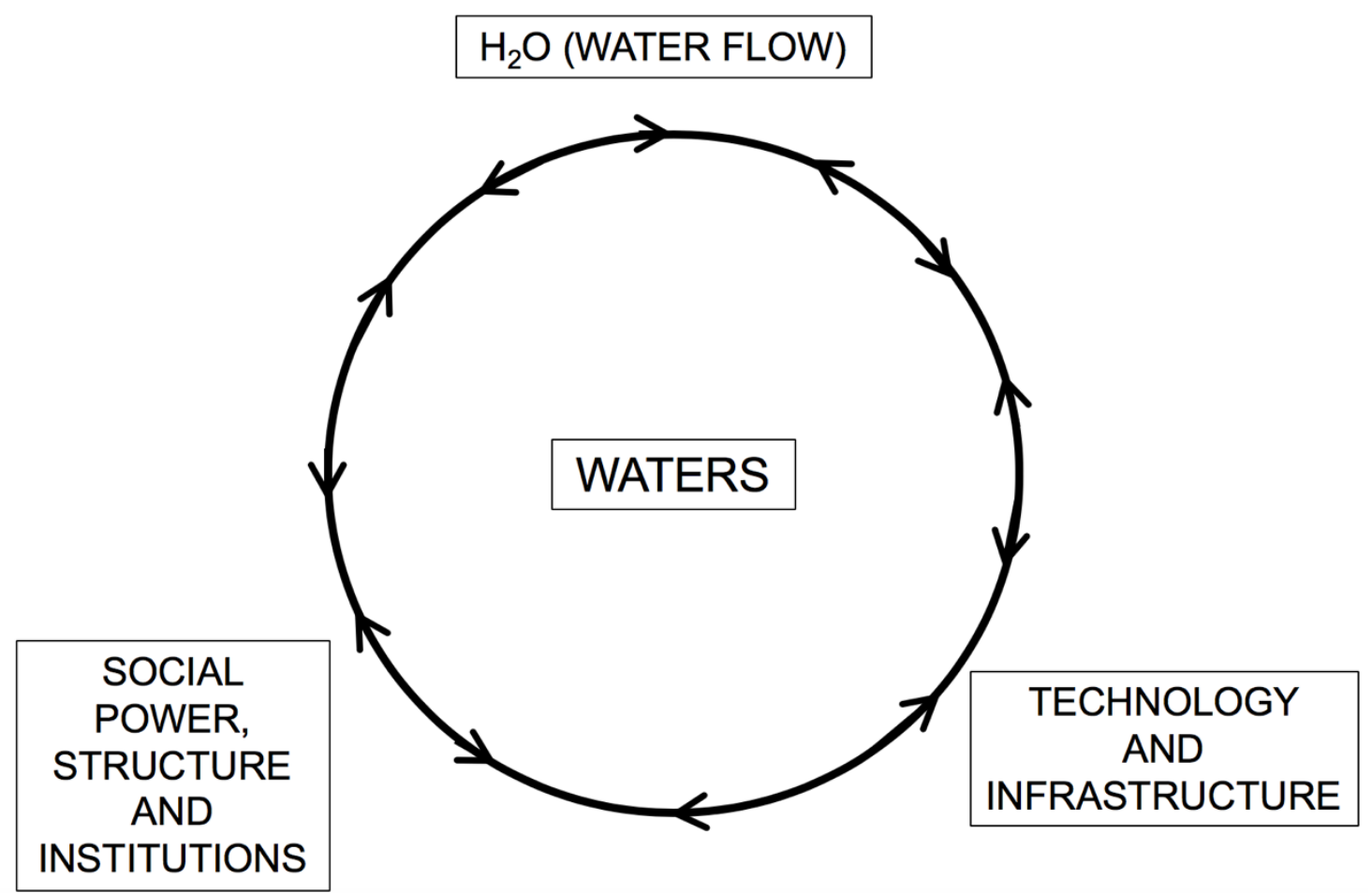

Figure 2: Diagram of the Hydrosocial cycle.

The social structure, power, and institutions component describes the social relations and behaviours, political structure, policy, and power relations that control where water flows, who gets access to it, of how much, and of what quality (Palomino-Schalscha, et al., 2016). This component elucidates that water circulation is dependent upon institutions, practices, and expectations as much as on the hydrological cycle, it is not just physically produced but socially enacted (Bakker, 2003). Part of this social enactment is defining the uses of freshwater, for example as a resource, supply, or waste, which is based on the value to humans, and therefore is a social and political act (Cousins, 2017b). Incorporating the social component in the cycle acknowledges that water circulation is socially and ecologically mediated through the hydrologic cycle, our bodies, and the network of pipes, and the power that controls them (Swyngedouw, 2006). Furthermore, it acknowledges that societies organise themselves around water, and that society shapes and is shaped by water (Linton and Budds, 2014). Therefore, this draws attention to how water is embedded in and internalises social relations, making it inherently political. Acknowledging the political allows for ideas of justice and power to be explored, within 
the context of water, to consider who gains and who loses, and the power relations involved (McGregor, et al., 2019).

The final component is infrastructure and technology, which includes: pipes, channels, stormwater, water treatment plants, taps, and water tanks, etc. (Linton and Budds, 2014). These are the forces that society uses to alter or manipulate the flow and properties of water. Infrastructure plays a vital role in how water is understood and used, for example in a pipe underground it is stormwater or coming out of a tap it is water supply. Therefore, infrastructure can change the flow and properties but also understandings and meanings around water, making it a vital component of the hydrosocial cycle (Swyngedouw, 2009). The hydrosocial cycle combines all of its components alongside each other, they are all interacting and can all change other components and the waters produced (Schmidt, 2014).

The hydrosocial cycle was adapted from the hydrological cycle which has been the dominant framework for understanding the hydrology of the world (Linton and Budds, 2014). However, the hydrological cycle separates the social from water, deeming it to be only a biophysical process. In contrast, the hydrosocial cycle illustrates that water cannot be classified as wholly natural, but rather it internalises social relations as a socio-natural entity (Schmidt, 2014). To represent this inseparability between water and society, the concepts of hydrology and society have been combined to form the hydrosocial cycle, which indicates that they should be considered simultaneously (Wesselink, et al., 2017). Furthermore, retaining the idea of the cycle was important to illustrate that the production of waters meanings is a process of transformation, not static in space or time (McGregor, et al., 2019). It is an ongoing cyclical process, where any change in one component of the hydrosocial cycle leads to a change in the other components and the produced meanings of waters (Linton and Budds, 2014). The cyclical nature means that there is no beginning or end to the process of making and remaking water and society; actions to control water movement always require infrastructure, that is controlled by power relations, which were informed by water flow (Linton and Budds, 2014). 
The particular type or representation of water that is produced is the manifestation of a given assemblage of the hydrosocial cycle components in a particular context (Cousins, 2017a). Assemblages are collections of entities, both human and non-human, that interact in various ways and change over space and time, so they are constantly forming and reforming (McGregor, et al., 2019). Therefore, this approach encourages a contextspecific exploration of the different assemblages of the components that produce water. Considering the assemblages in a specific space and time allow for the many social and cultural meanings of waters to be explored (Wesselink, et al., 2017). For example, examination of how different groups of people, with different social structures and interactions with $\mathrm{H}_{2} \mathrm{O}$ and infrastructure, understand water. This highlights the plurality of meanings of water that the hydrosocial cycle can produce in each specific time and space, but that also changes within and across time and space (Linton and Budds, 2014). Acknowledging this plurality challenges the dominance of a single way of knowing water that informs policy (Thomas, 2015). Therefore, a hydrosocial approach dismisses the idea that there is one reality of water that is knowable, and instead highlights that there are multiple ways of being with water and understanding water places (Yates, et al., 2017; Gibbs, 2014). Within the context of Aotearoa-New Zealand, a Western understanding of water as a resource predominates freshwater policy (Tipa, 2009). However, this is only one way to understand water. Tipa (2009) describes a Māori worldview as having distinct perspectives of water; that it reflects identity, attachment to place, knowledge, and custodial obligations. She describes water as something to engage with and respect, that should be regarded with humility, awe, care, reciprocity, and love, to acknowledge its beauty and dangers (Tipa, 2009). Therefore, embracing tikanga Māori can open the opportunity to gain rich and diverse information derived from Māori science, perceptions, meanings, and values ascribed to water (Tipa, 2009). The hydrosocial cycle enables exploration of how various people's experiences, meanings, values, and practices change how they perceive water.

The hydrosocial cycle has evolved over the past two decades to offer a useful lens for understanding water and power. Work by Swyngedouw (1996; 2006; 2009) was foundational in the study of hydrosocial relations of urban water. His work focused on the historical process of urbanisation and the simultaneous transformation of the 
circulation of water. He employed the hydrosocial cycle to explore how water shapes the built environment and the infrastructure used to control it, and how the production of the city and the alteration of water flows are simultaneous. A key tenet of his work has been exploring ideas around cities being socio-natural entities (Swyngedouw, 2006). Bakker (2003; and 2012) expanded ideas about social urban water when she focused on the privatisation of water supply around the world, and the way power is used to control the distribution of water. She highlighted how water is used to marginalise the poor, and therefore, is embedded in social processes (Bakker, 2003). Cousins (2017a) also examined the politics involved in water governance over stormwater. His use of a hydrosocial cycle lens allowed analysis of the power relations that dictated who was entitled to what quality, kind, and volumes of water and who should control, manage, and make decisions about water. Power relations were also examined by McGregor, et al. (2019), but for carbon when they repurposed the hydrosocial cycle to study the carbon cycle as the sociocarbon cycle in the REDD+ project in Indonesia. It works on the same premise, that carbon is more than just the $\mathrm{C}$ atom, but is a manifestation of infrastructure, technology, social structure and power. The work of McGregor, et al. (2019) provides an in-depth example of the process of examining an issue through a sociocarbon cycle lens and the extra nuance analysis can have when using this framework.

\subsection{The Gap, Research Questions, and Aims}

While the hydrosocial cycle has provided a useful framework for thinking about urban freshwater, research to date has largely overlooked urban streams. Due to the complexity of urban streams, current technocratic regimes fail to manage them appropriately as they attempt to separate the physical from the social. Therefore, it is important to use a framework that combines these diverse components of urban streams, such as the hydrosocial cycle, to explore urban streams to improve management into the future. In response to this need, this research explores how the hydrosocial cycle can be used to explore a specific buried stream in Te Whanganui-a-Tara-Wellington, Aotearoa-New Zealand. I ask: 
Using the case study of the Waimapihi Stream, how can the hydrosocial cycle be used to explore the meanings of urban streams and how they are valued?

The theoretical aims of this research are: 1) to contribute to the critical theory around the use of the hydrosocial cycle as a theoretical framework to explore freshwater in cities in Aotearoa-New Zealand; 2) to contribute to literature about buried streams in Te Whanganui-a-Tara-Wellington; 3) to contribute to the literature on the Waimapihi Stream. This project will focus on the Waimapihi Stream to use this rich social and cultural context to explore how the hydrosocial cycle can be used to examine urban streams. This will enable the investigation to be in-depth and situated as it will explore many of the interactions of the hydrosocial components that are occurring in this urban stream. This will demonstrate how the hydrosocial cycle has value to examine the many intersecting components that make up an urban stream. The social aim of this research is to develop a relationship with the Waimapihi, and its community, and the organisations that work with it to start a conversation about an alternative future than its current projection.

A hydrosocial cycle approach using a more-than-human methodology guides the design and execution of this research. This more-than-human methodology will enable exploration of the role and agency of humans, non-humans, infrastructure, and water in the production of the Waimapihi Stream. Taking this methodological approach informed my choice of mixed, messy methods. The methods that were mixed together messily were fish spotlighting and semi-structured interviews. Fish spotlighting explored the presence and absence of fish in the Waimapihi Stream. Insights from semi-structured interviews with a range of people connected to the Waimapihi provided detailed accounts of their interactions with and understandings of the stream. Research findings were developed from thematic analysis of data produced from these mixed, messy methods. Critical geography literature, particularly social theory of nature, freshwater geographies, hydrosocial cycle, more-than-human theory, and animal geographies, shaped discussions around findings of the meanings, definitions of, and the interactions, both human and nonhuman, with the Waimapihi, and how a hydrosocial cycle approach can facilitate this. 


\subsection{Thesis Structure}

This thesis unfolds from here as follows: Chapter Two sets the context of Te Whanganuia-Tara-Wellington and the Waimapihi Stream, with a brief description of the physical, social, and cultural context of the city and the past of the stream. Chapter Three delves into the research process, examining my epistemological foundations, hydrosocial theoretical framework, my more-than-human methodology, fish spotlighting, semistructured interviews, and thematic analysis. Chapters Four, Five, and Six discuss the ideas that emerged out of analysis of data related to the research questions around the Waimapihi Stream. Chapter Four explores how the Waimapihi is understood as a stream and how this changes over space and time. Chapter Five explores the changing interactions of non-humans with the stream over space and time. Chapter Six explores ways people connect with the buried section of the stream now and could in the future. These chapters investigate the changes in these understandings and interactions over time and space, with an exploration of the possible alternative futures for the Waimapihi. They offer examples on, analysis, and discussion of the ways the hydrosocial cycle can be used as a framework to explore the multiplicity of meanings, values, and perceptions around the Waimapihi Stream. To conclude, Chapter Seven will summarise some of the meanings of the Waimapihi at present and into the future, and along the stream. It will present the possibilities the hydrosocial cycle approach would bring to urban freshwater policy in Aotearoa-New Zealand and more specifically Te Whanganui-a-TaraWellington. 


\section{Chapter Two: Context and Past of the Waimapihi Stream}

\subsection{Introduction}

This chapter will describe the physical geography of Te Whanganui-a-Tara-Wellington to set the scene for this research. It will then examine the impacts of waves of Māori migration, colonisation, and urbanisation on the physical geography. Finally, how these threads culminated in the piping of the Waimapihi will be explored. This chapter examines the physical, social, and cultural context of the Waimapihi Stream, which is vital for carrying out research in a place (Blue, 2018). Understanding the past intersecting processes occurring in the stream signals some of the processes happening both now and into the future, and how they influence perceptions of the Waimapihi and its place in the city. This is important as most of Aotearoa-New Zealand's major cities are coastal and stream burial is not unique to Te Whanganui-a-Tara-Wellington, consequently, coastal streams are threatened ecosystems (McEwan and Joy, 2009). Furthermore, the modification of these streams has reduced their resilience to heavy rainfall events, leaving Te Whanganui-a-Tara-Wellington, and other cities, increasingly vulnerable to flooding (McConchie, et al., 2000).

\subsection{Physical Geography of Central Te Whanganui-a-Tara-Wellington}

The greatest influence on the topography of Te Whanganui-a-Tara-Wellington is tectonic activity (McConchie, et al., 2000). The regions geologic history has been variable, with periods of activity and quiescence, however, the current period is predominated by 
activity. The tectonic setting is dominated by the subduction of the Pacific plate beneath the Indo-Australian plate to the east of Te Ika a Māui-North Island, causing the frequent and dramatic tectonic activity experienced (McConchie, et al., 2000). Around the Te Whanganui-a-Tara-Wellington Harbour, tectonic uplift raised the land in relation to sea level, resulting in the landscape of a harbour surrounded by uplifted coastal landforms. The Mōhaka-Wellington fault runs along the western side of the Te Whanganui-a-TaraWellington Harbour, through the central city in a NE-SW orientation (McConchie, et al., 2000). There are also three other faults in the region: Pukerua, Ohariu, and Wairarapa. A faultline is a zone of weakness where the pressure from the subduction of the two plates builds up until it is greater than the strength of the material at which point it relieves the stress, and therefore, is a site of activity. The activity of these faultlines has influenced the complex faulting pattern topography of the city, producing a drainage network of hills and valleys through which streams flow. Many streams have eroded their courses along faultlines because the crushed rock material at the fault is more easily eroded than the surrounding bedrock. This stream network flows down the hills onto floodplains, such as Te Aro Flat, and into the Te Whanganui-a-Tara-Wellington Harbour which is roughly circular and semi-enclosed with one entrance to the Raukawa-Cook Strait (McConchie, et al., 2000).

The other major driver of the topography of Te Whanganui-a-Tara Wellington is climatic processes, particularly the oscillations between glacial $\left(2-5^{\circ} \mathrm{C}\right.$ colder $)$ and interglacial (current conditions) (McConchie, et al., 2000). These conditions influenced the vegetation, with dense rimu podocarp forest dominating in interglacial times; and scrub, alpine grassland and bare ground in glacial times (McConchie, et al., 2000). Loss of vegetation cover led to increased hillslope erosion due to exposure of the soil surface and weathering such as freeze-thaw. The increased erosion led to wider and longer beds of waterways and increased sediment movement within them. Sea level also lowers as water is tied up in ice, snow, and glaciers, exposing more land to weathering. Comparatively under interglacial conditions the landscape was dominated by dense forest, reducing erosion due to weathering. The waterflow of streams is greater but the reduced exposed land causes waterways to downcut, rather than widen, and rework the landscape. Te Whanganui-a-Tara-Wellington is highly dynamic, with changing tectonic and climatic 
activity that is continually adjusting in an attempt to reach equilibrium producing the landscape of the city (McConchie, et al., 2000).

The topography of Te Whanganui-a-Tara-Wellington alongside its location in weather circulations produces very distinct and sharp climatic gradients, producing the high winds and rainfall the city is known for (McConchie, et al., 2000). The average rainfall is 1230 $\mathrm{mm} / \mathrm{yr}$, however, it varies greatly across the city, but is fairly consistent throughout the year, with only a slight increase in winter (McConchie, et al., 2000). The city has a wet climate, but storage of water in lakes and reservoirs is limited due to the steep topography resulting in rapid runoff of rainfall as streamflow. This limited storage capacity produces highly variable streamflow because rainfall events result in high streamflow, which is separated by sustained periods of low baseflow. These high flow events tend to cause flooding periodically and have influenced the production of flat floodplains, such as Te Aro flats, downstream due to sediment erosion and deposition. Te Aro Flats are where the Waimapihi Stream would have flowed openly down from the hills in Aro Valley and then into Te Whanganui-a-Tara-Wellington Harbour. Therefore, when first Maori and then European settlers migrated to the region the only flat land was on the coastal floodplains, which were dominated by swamp vegetation, and the rest of the land was steep hills and valleys, covered in dense forest and littered with stream networks (McConchie, et al., 2000).

\subsection{Māori Migrations and Settlement}

This is a very simplified version of the migrations of iwi to and from Te Whanganui-aTara-Wellington in order to outline the mana whenua of the Te Aro area where the Waimapihi flows. Many iwi occupied and passed through Te Whanganui-a-TaraWellington for many generations resulting in a complex history of the region. There is evidence of middens, shells that indicate old shellfish food dump sites, dating back approximately 600 years in the area indicating Māori have inhabited the land for at least 600 years ( $\mathrm{Z}$ Energy, 2013). Kupe is regarded as the discoverer of Aotearoa-New Zealand; he circumnavigated the country naming places along the way in approximately 
1200 AD (Waitangi Tribunal, 2003). Subsequently, Whatonga explored the area of Te Whanganui-a-Tara-Wellington and named the harbour after his son Tara, hence Te Whanganui-a-Tara (the harbour of Tara). Descendants of Tara, including the peoples of Ngāi Tara, occupied the area in the $18^{\text {th }}$ and $19^{\text {th }}$ century, alongside Ngāti Mamoe, Ngāi Tahu, and Ngāti Ira people (Love, 2005). As Māori occupied the region they cleared some of the dense forest to build pā and kainga, mainly around the harbour and the area that is now Matairangi-Mount Victoria, which altered the physical landscape of the region (Maclean, 2007).

Between 1817 and 1835 there were four waves of migration of many iwi from Taranaki south to Te Whanganui-a-Tara-Wellington (Tenths Trust, n.d.). There were many reasons for these migrations, including pressure from Waikato iwi and a desire to explore the south. These southern migrations from Taranaki influenced Ngāi Tahu and Ngāti Ira to move south to Te Waipounamu-South Island and Ngāti Mamoe to the Wairarapa (Love, 2005). Taranaki Whānui ki Te Upoko o Te Ika (Taranaki Whānui) is the collective name of the mana whenua of Te Whanganui-a-Tara-Wellington, which includes: Te Ati Awa, Taranaki, Ngāti Tama, Ngāti Ruanui, and Ngāti Mutunga, who continue to live and maintain ahi kā in the region (Port Nicholson Block Settlement Trust, 2012a). The Port Nicholson Block Settlement Trust is the organisation of local iwi that submitted a Waitangi Tribunal claim about the land in the city and they now manage the settlement for the local iwi. The rohe of Taranaki Whānui (figure 3) includes Te Aro Pā on the western edge of the Te Whanganui-a-Tara-Wellington Harbour, which is where the Waimapihi Stream is located (Port Nicholson Settlement Trust, 2012b). 


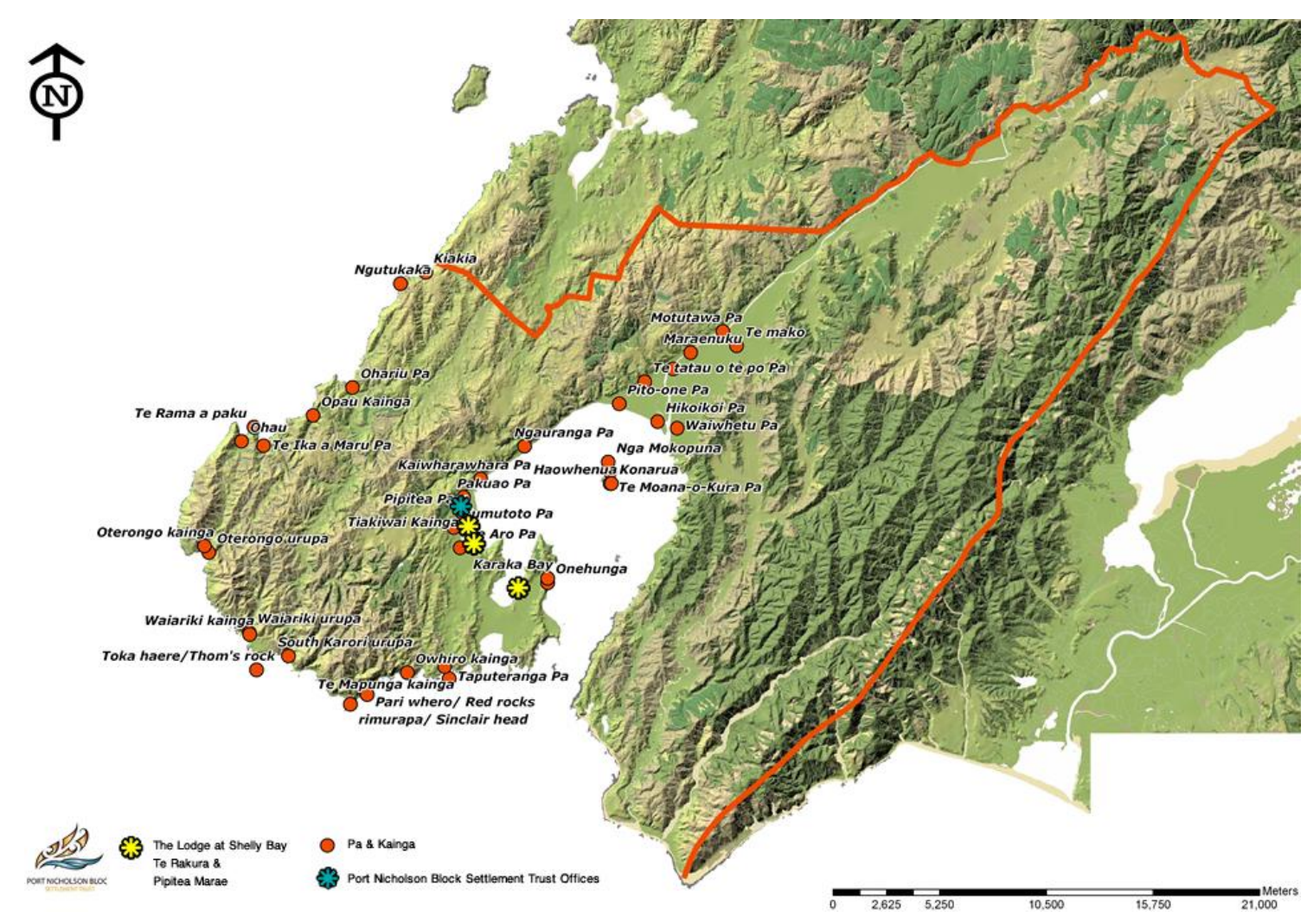

Figure 3: Taranaki Whānui ki Te Upoko o Te Ika rohe, with Te Aro Pā located next to a yellow star. Retrieved from Rohe, by Port Nicholson Block Trust, (2012b), Retrieved from http://www.pnbst.maori.nz/rohe/PNBST_Rohe.html

Te Aro Pā, a fenced village rather than defence pā, was established by Ngāti Mutunga in 1824 (Love, 2005). Subsequently, they left and the pā was split with Ngāti Ruanui occupying the eastern end and the two hapū, Ngāti Haumia and Ngāti Tupara, occupying the western end (Waitangi Tribunal, 2003). The Waimapihi flowed to the west of Te Aro Pā (Waitangi Tribunal, 2003). The Waimapihi was named after Mapihi, a rangatira of Ngāi Tara and Ngāi Mamoe, who bathed in the stream, estimated around the $18^{\text {th }}$ century (Love, 2005). The inhabitants of the pā regarded the Waimapihi Stream as a sacred waterway; it was an important mahinga kai site and a source of water for drinking and irrigation of kumara and flax cultivations (Waitangi Tribunal, 2003). The fish populations in the Waimapihi would have been greater in number and species. It is expected (in relation to populations in similar streams) that there would have been inanga and bullies in addition to the banded kōkopu, kōaro, and kōura that currently inhabit the Waimapihi (Boubée, et al.,1999). 


\subsection{Impacts of Colonisation and Urbanisation on the Physical and Social Landscape of Te Whanganui-a-Tara-Wellington}

Sailing the Lambton, Captain Herd was the first European settler to land in the Te Whanganui-a-Tara-Wellington Harbour in 1826, calling it Port Nicholson (McConchie, et al., 2000). The first immigrant ship of Great Britain's ‘New Zealand Company’ (NZC) Aurora arrived in early 1840 (McConchie, et al., 2000). European settlement brought about significant changes to the settlement of the local iwi as settlers dubiously 'purchased' land from them (Love, 2005). Roberts, et al. (1995) describe how Māori believe you cannot own the land, you can only occupy it and the relationship with the land is through whakapapa. In contrast, Europeans believe land to be a commodity to be exploited and traded, therefore, their settlement and introduction of laws altered understandings of land ownership in Aotearoa-New Zealand (McConchie, et al., 2000). The relationship with rivers and streams also differed, with Māori viewing them as a sacred entity and settlers valuing them for their utility (Brierley, et al., 2018). These ideas of land ownership and property fragmented the land as it was surveyed into parcels for individualised and privatised land deals with incoming settlers (Brierley, et al., 2018). This subdivision and development of the land led to massive clearance of native vegetation, drainage of wetlands, and modifications of the landscape. Examples include 'cut and fill' methods of filling in valleys with land from hills to flatten land to build on, to create large areas for urban development and pastoral farming (McConchie, et al., 2000).

Te Aro Pā was built on the Te Aro Flat floodplain near the Lambton Harbour, in a prime location for the development of the city, so was desirable land for settlers. It was located where the intersection of Courtney Place and Manners Street now is and ran down to the shore which is now Wakefield Street (Waitangi Tribunal, 2003). Te Aro Pā was included in some of the parcels sold to incoming settlers, however, the Te Aro Māori refused to 
sell the land they occupied. Therefore, when settlers arrived, they found the land they had bought was occupied by Māori communities.

During the settlement of Te Whanganui-a-Tara-Wellington by colonialists, the tenths reserves scheme was developed as a method to divide land into rural and urban sections (Tenths Trust, n.d.). In the 1839 deed of purchase, devised by William Wakefield on behalf of the NZC, there was a promise that Māori would retain their pā, kainga, cultivations, and mahinga kai sites, and one-tenth of the land in Te Whanganui-a-TaraWellington. Then in 1841, some reserve land was rented out to settlers with the income intended to go towards education and medical help for Māori, however, it generally went towards Crown costs (Tenths Trust, n.d.). The site of Te Aro Pā was considered some of the most valuable land in the city and many settlers voiced their opposition to the land being reserved for the local Māori. Te Aro Pā was perceived as a slum by colonial settlers and the authorities, such as Commissioner Heaphy of NZC, who wished to see Te Aro Pā removed from the city and encouraged the sale of plots of the pā. The settlers and authorities put pressure on and inflicted violence against Māori communities to leave and swap their land for places elsewhere (Waitangi Tribunal, 2003).

Additionally, the 1855 earthquake that struck Te Whanganui-a-Tara-Wellington caused land to uplift, draining the swampy areas that had been a source of food and flax that provided income for local Māori as it was sold to settlers (Waitangi Tribunal, 2003). This loss of food and trade source, alongside illness from imported diseases and migrations back to Taranaki to deal with land disputes, reduced the Māori population at Te Aro Pā (Love, 2005). The rest of Te Aro Pā was surveyed into allotments for renting by 1868, then all the land of Te Aro Pā was sold under duress by 1873, until finally the pā was completely unoccupied by Māori by 1890 (Waitangi Tribunal, 2003). The loss of land to Māori significantly impacted upon their social and economic structures, therefore, the colonisation of Te Whanganui-a-Tara-Wellington has had significant impacts on the wellbeing of Māori, which is ongoing to the current day. 


\subsection{The Burial of the Waimapihi Stream}

The above processes paved the way for the burial of the Waimapihi Stream, which began around the 1860s ( $\mathrm{Z}$ Energy, 2013). The combined impacts of the 1853 flooding, 1855 earthquake uplift, health impacts of sewerage and general pollution of streams, and the development of the city including reclamation of coastal land, has altered the city's stream network extensively (Wellington City Council, 2013). This section describes the events leading up to and the process of the burial and piping of the Waimapihi.

As mentioned above, the Waimapihi flowed over a floodplain, and the processes that produced this flat land to build on also impacted what was built on it (McConchie, et al., 2000). Consequently, the Waimapihi was becoming a nuisance as urbanisation processes accelerated after colonial settlers moved in and began building houses and infrastructure around the stream. Furthermore, the removal of vegetation from the region had reduced the buffering qualities it provided, leading to larger floods in the region (McConchie, et al., 2000). The specific flood that caused significant damage was the March 1853 flood, where many streams in the city overtopped their banks, including the Waimapihi (National Library of New Zealand, 1853). Heavy rains had fallen the few days before, which accumulated in the swampy lowlands of Te Aro Flat, causing the narrow bank that separated the stream from the sea to burst. The stream flooded into the harbour and the vast flow of water brought with it large amounts of sediment and washed away many flax plants. This torrent of sediment and flax burst across streets on the shore of Lambton Harbour, causing significant damage to buildings and infrastructure.

Not long after the flood there was another event, the 8.2 magnitude earthquake of January 1855 (McConchie, et al., 2000). The earthquake raised land between 0.5-1.5 $\mathrm{m}$ in the city including the land around the Te Aro Flats next to the Lambton Harbour. This resulted in the swampland of Te Aro Flat being drained and the flow of the Waimapihi Stream reduced. 
The Waimapihi flowed right through the centre of the developing Te Whanganui-a-TaraWellington, causing health issues for residents because it was used as a sewer. There was no sewerage system in the early days of the city; the custom of European settlers was to use streams as drains and sewers as they provided conduits for disposal of waste that was removed with the flow into the Harbour (Brierley, et al., 2018). The influx of effluent into streams led to increases in diseases, such as typhoid, diphtheria, and scarlet fever, resulting in illness and death of residents (McConchie, et al., 2000).

The last reason for piping the Waimapihi was to open more land up to be developed for the fast-growing city (Wellington City Council, 2013). Piping the stream underground allowed buildings and roads to be built on top of the stream. The piping was aided by the earthquake, uplifting the land and draining the swamp and so reducing the flow of the stream. Previously undevelopable land became developable, resulting in an acceleration of urbanisation in the area. This desire for more developable land influenced the reclamation of land into Lambton Harbour, again aided by the uplift of land from the earthquake. Much of the land in Te Aro Pā was sold for land reclamation projects which were first proposed in the early 1870s but did not occur until 1886 (Waitangi Tribunal, 2003). The Waimapihi was piped in sections over time as areas of the city were developed, with most of the length piped by the late 1890s.

\subsection{Introducing the Waimapihi in its Current State}

Today, the Waimapihi has an open and piped section and flows through the central city (figure 4). The open headwaters are in the Waimapihi Reserve. Downstream the piped section flows under Aro Valley, Aro Park and Aro Valley Preschool, Palmer Street, then flows diagonally (under Vivian Street and Cuba Street) towards the Lambton Harbour, where it outfalls at Taranaki Street Wharf. 


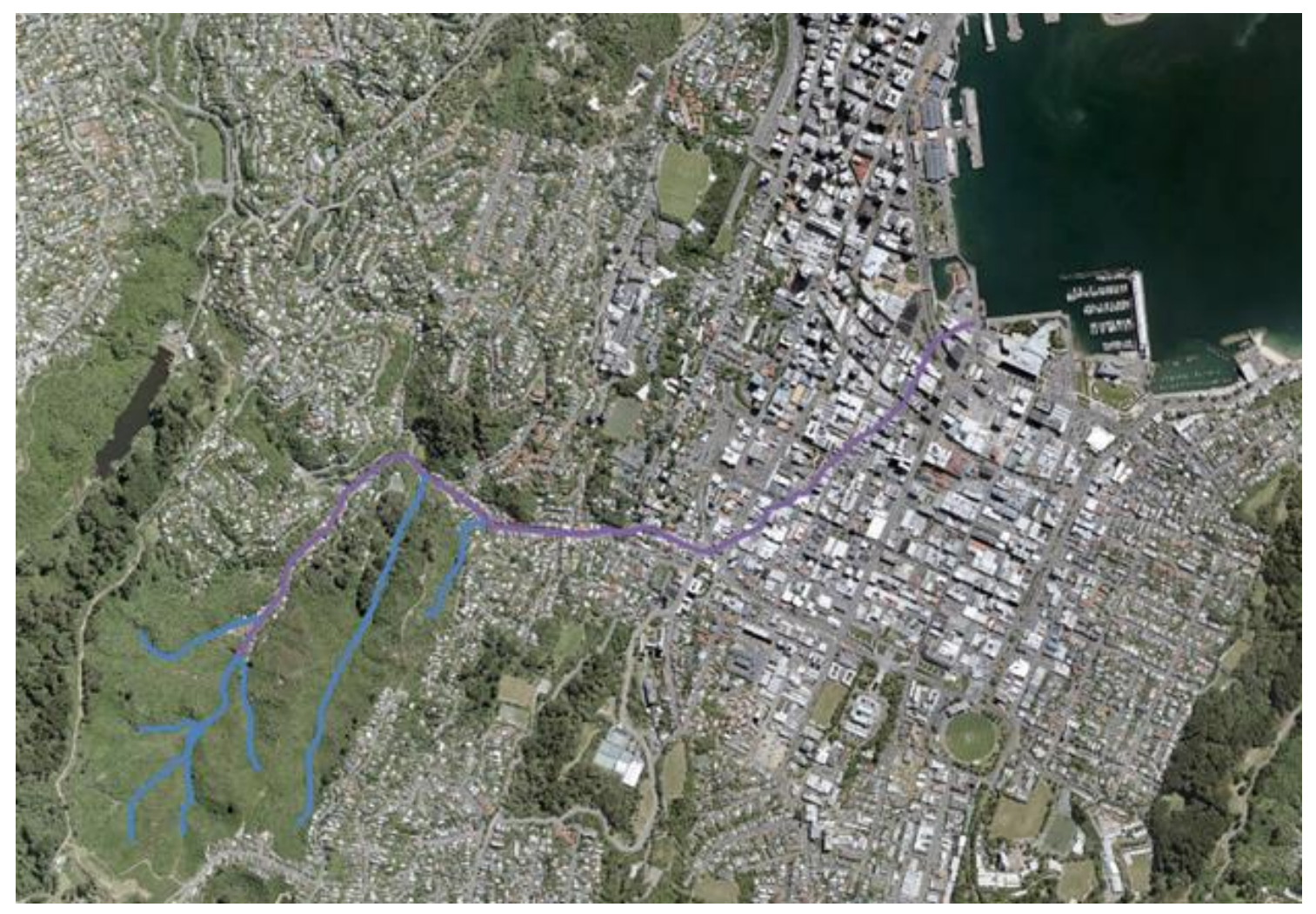

Figure 4: Map of Waimapihi Stream with piped section in purple and open sections in blue. Adapted from Water and Drainage-LocalMaps, by WCC, 2019, Retrieved from:

https://gis.wcc.govt.nz/LocalMaps/Viewer/?map=57fb534c2174471ca485132112088afc

The burial of streams, such as the Waimapihi, has influenced how they are legally understood. The Resource Management Act (RMA) (1991) governs environmental management and development in Aotearoa-New Zealand (Department of Internal Affairs, 2017). Above the pipe the Waimapihi is legally a stream, but once it enters the pipe it is not. According to the legislation, the definition of a river does not include "any artificial watercourse" such as a piped stream, and the definition for water "does not include water in any pipe" (Resource Management Act, 1991). Therefore, once in the pipe the Waimapihi does not receive the legal protections surface streams get, including restrictions on incoming discharge. The law in Aotearoa-New Zealand, as it stands today, ignores most of the length of the Waimapihi because it is buried in a pipe and is thus not even considered water. This piped length of the Waimapihi is the thoroughfare for Indigenous fish species but has no legal protections or restrictions on modification and pollution, and monitoring of water quality and fish life is not required. This has implications for how the Waimapihi is valued and understood, and therefore, how it is 
managed and protected. This physical and legal complexity informed the choice of the Waimapihi as the case study for this research.

\subsection{Conclusion}

The context and history of Te Whanganui-a-Tara-Wellington must be acknowledged to enable any attempt to understand the Waimapihi Stream with any real depth. This chapter has briefly described the physical geography of Te Whanganui-a-Tara-Wellington and the impacts of Māori and colonial settlement and occupation. Secondly, the events leading up to and the process of piping of the Waimapihi were examined. Finally, a brief description is provided of the current state of the Waimapihi Stream, with the open headwaters in the Waimapihi Reserve and the piped path to the Harbour, and how these different forms are understood under the RMA (1991). The Waimapihi Stream takes many forms as it flows from the headwaters in Waimapihi Reserve to the Harbour. This research aims to explore the meanings and values that people hold along the stream, and how the different forms influence these. I will explore the social and physical processes that produce the waters of the stream, and how the water and life within the stream shapes social structures, relations, and identities over space and time. 


\section{Chapter Three: Methodology and Theoretical Underpinnings}

\subsection{Introduction}

A common critique of freshwater management in Aotearoa-New Zealand has been that it is often highly fragmented and technocratic. The current approach is dominated by Western science which, while providing useful insights, often breaks an ecosystem into separate parts rather than understanding it as a whole (including interactions with humans and what they produce). Therefore, to explore the Waimapihi Stream, which is highly modified, it was important to take an approach that drew together its different components. The hydrosocial cycle is a framework that draws together these various components. I begin this chapter with a description of this approach. I decided to discuss the theoretical framework here alongside the methodology because they are interlinked. The hydrosocial cycle was instrumental in how I embarked on this research, in my epistemology and choice of methodology. I explain how the hydrosocial cycle shaped what I did in the project, as well as the ethical considerations and my positionality. I also delve into some of the conundrums faced while trying to choose my methodological approach. I end the chapter with a description of the methods and analytical approach used.

\subsection{Theoretical Framework and Epistemology}

The hydrosocial cycle was the framework chosen to drive this research and examine the different meanings of water in the Waimapihi Stream. A hydrosocial approach leads to a situated study of a waterway, through investigation of the interaction of the specific 
assemblages of the components of the cycle to produce the waters of that place (Cousins, 2017a). Situating the exploration in the social and cultural context acknowledges the social quality of water processes, which allows for the politics around defining and managing water to be acknowledged, explored, and therefore challenged (Schmidt, 2014). This section describes how the hydrosocial approach informed the social constructivism epistemology used.

The hydrosocial cycle is a way for the discourse around water management to move away from the dominance of experts, to also include the situated knowledges of locals about the interactions between people and water, for a more inclusive and effective practice (Allon and Sofoulis, 2006). It provides space for local knowledges of places to be investigated and incorporated into management by encompassing the social. This is valuable because people can have a deep knowledge of their local area from daily lived experience of functional relationships and processes of their environment, which should not be dismissed (Robbins, 2012). Their knowledge (taken seriously), alongside or informing technical expert or scientific knowledge, can enable a much more comprehensive understanding of a waterway.

Part of this shift in management, the hydrosocial cycle provides a framework for critiquing "taken for granted" understandings of freshwater by examining the political nature of these understandings. For example, the idea of watershed as the "natural" unit for managing freshwater, which has permeated policy and current management across Aotearoa-New Zealand. A hydrosocial approach illustrates that concepts, like watershed, are defined by humans and keep changing as techniques improve. These humans defined managerial units influence who has access to how much water, and therefore are social and political, not just technical (Yates, et al., 2017). Examining water issues through the hydrosocial cycle can explore the assumptions made around hydrological concepts, methods, and data to expose the political forces behind them. This examination allows for the consideration of what is measured and managed, and why; and the influence this has on how waterways are treated and understood (Blue and Brierley, 2016). 
Therefore, the hydrosocial cycle provided an analytical lens to direct my thinking about urban freshwater and the Waimapihi Stream, allowing me to disregard my preconceived notions of what I thought a stream to be (Palomino-Schalscha, et al., 2016). The framework enabled examination of the complex and intersecting components that make up water and waterways. The hydrosocial cycle investigates the context - how institutions, knowledge, and biophysics come together in a particular time and place to produce water. In doing so, it provides a framework to amalgamate social processes and structures, with physical geographies in a way that other approaches don't enable (Linton and Budds, 2014). The politics of defining streams is so intrinsically related to their treatment and biophysical state that it must be addressed. The social construction and production of waters; of streams, stormwater, and discharge, and the ways they are made known, must be unravelled to make any critical examination of water possible (Linton and Budds, 2014). The hydrosocial approach facilitates exploration of the role of water in shaping urban dwellers lives and changing social structures, because it considers relations and patterns that are otherwise ignored under different approaches (Yates, et al., 2017). The social practices and power relations acting on and with the Waimapihi, that might otherwise be invisible, can be examined using a hydrosocial approach (PalominoSchalscha, et al., 2016). Through the Waimapihi, this research examines the definitions of streams and water in the urban centre of Te Whanganui-a-Tara-Wellington and the different roles and values people place on these waters. It examined the production of different meanings and knowledges about water that informed management of the Waimapihi and stormwater.

The critical lens encouraged by a hydrosocial approach informed the social constructivism epistemology underlying the research approach taken. Exploring our epistemology allows us to uncover and challenge the assumptions that we hold about knowledge, such as what knowledge we think is possible or deem legitimate, that shapes how we conduct research and present our research outcomes (Smith, 1999). Social constructivism rejects the idea that there is objective knowledge in some external reality for the researcher to neutrally discover. Instead this approach suggests that truth and meaning are constructed from our engagement with the world, and our experiences and interactions with what surrounds us (Costantino, 2008). As a result, social constructivism 
illustrates that there are multiple knowledges and people make sense of the world through their cultural, historical, and social lenses (Creswell, 2014). Therefore, different societies and cultures have different interpretations of knowledge and concepts that change over time (Kulka, 2000). However, Western academia sometimes deems some knowledges legitimate over others, by requiring them to be presented in elite languages and formal texts where one must reference peer reviewed research to get published (Todd, 2016). This can mean local knowledges, which are often transmitted orally and in local vernacular, are overlooked as legitimate research by Western academia (Robbins, 2012). Recognising that knowledge is limited, specific, and partial, and that the context and circumstances under which it is produced shape it, challenges Western academia's claims of universally applicable knowledge (Rose, 1997). This highlights that the world we inhabit exceeds human control and representation, and that we will never know everything about the world (Dowling, et al., 2017). It illustrates that being objective is impossible, so leaning into the politics and exploring the power relations in the research and the processes being researched is more transparent and fruitful (Blue and Brierley, 2016).

Social constructivism enables "taken for granted" concepts and knowledge sets, such as the hydrological cycle, to be questioned. The hydrological cycle is the dominant theory that informs our understanding of the movement of water (Linton and Budds, 2014). However, this theory can be traced back to civil engineer and soil scientist Robert Horton, through his work for the United States Geological Survey (USGS) (Horton, 1931). He separated out different processes of water movement and defined the hydrological cycle after his work on streams in the New York District (Horton, 1931). A description of the hydrological cycle was first published by Horton in 1931 in 'The field, scope, and status of the science of hydrology'. This research was carried out in a specific social, historical, and cultural context: in the USA, under the state-run organisation the USGS, in the 1930s, and under the field of engineering (Linton and Budds, 2014). Furthermore, it was developed in the temperate climate of the USA, meaning there is a temperate bias in the cycle. This bias has informed assumptions around unlimited water resources that has led to the quest for constant water availability across the world, including in arid regions, which has influenced water supply challenges (Bakker, 2012). The hydrological cycle has 
become ubiquitous in hydrology and wider understandings of water, but the context of the theory is rarely explored when it is being applied. This exemplifies how a generalising theory ignores the social, cultural, and physical context. It also highlights how a certain narrative around water has dominated, due to the power behind who and where the narrative was produced. This does not disregard the value of the hydrological cycle as a globally useful theory, but provides an example of how we can often use theories without exploring their origins and just accept them to be true. Using a social constructivism lens to understand the hydrological cycle encourages critique of the social, historical, and cultural context that it was produced and is enacted within (Kulka, 2000).

In this research, I have taken a social constructivism lens to investigate freshwater management, to explore competing ideas and how different ideas have been seen as common sense at different times (Costantino, 2008). This lens allows for an in-depth critique of these assumptions, to deconstruct them, which may allow for innovative, respectful, and alternative management regimes to be explored and enacted. This research used a social constructivism approach to examine the different ways urban freshwater, including streams and stormwater, are perceived. Therefore, this in-depth examination of the Waimapihi Stream, which has an open and piped section, allowed for an exploration of how the hydrosocial cycle can provide a useful framework to consider all the intersecting components that make up a buried stream and the implications of these on understandings of them.

\subsection{Positioning Myself in the Research}

My first memories of the Waimapihi Stream are from my childhood, spending time there with friends. In particular, I remember my friend's eighth birthday party. We did a World of Wearable Arts show where we made costumes from bits of fabric, and then went for a walk to the Waimapihi Reserve, figure 5. I recall thinking it was strange there was a pool and cage on the stream, which I now know to be the entrance to the piped section. Years later, when studying physical geography in Ōtepoti-Dunedin, I made connections 
between the Waimapihi and the highly altered Leith River that flows through the city and university. Both waterways represented ways streams and rivers had been constructed and controlled. Coming back to Te Whanganui-a-Tara-Wellington to study, I found myself returning to ideas about what streams are and in particular urban streams. The Waimapihi seemed like the best place to start, in the community where I grew up, and still live, and have childhood memories and long-term connections. I felt that having this familiarity and local knowledge of the area meant that I would be able to delve deeply into the questions that had begun to form around how we treat waterways in cities and why, and whether we could imagine the place of freshwater in cities differently.

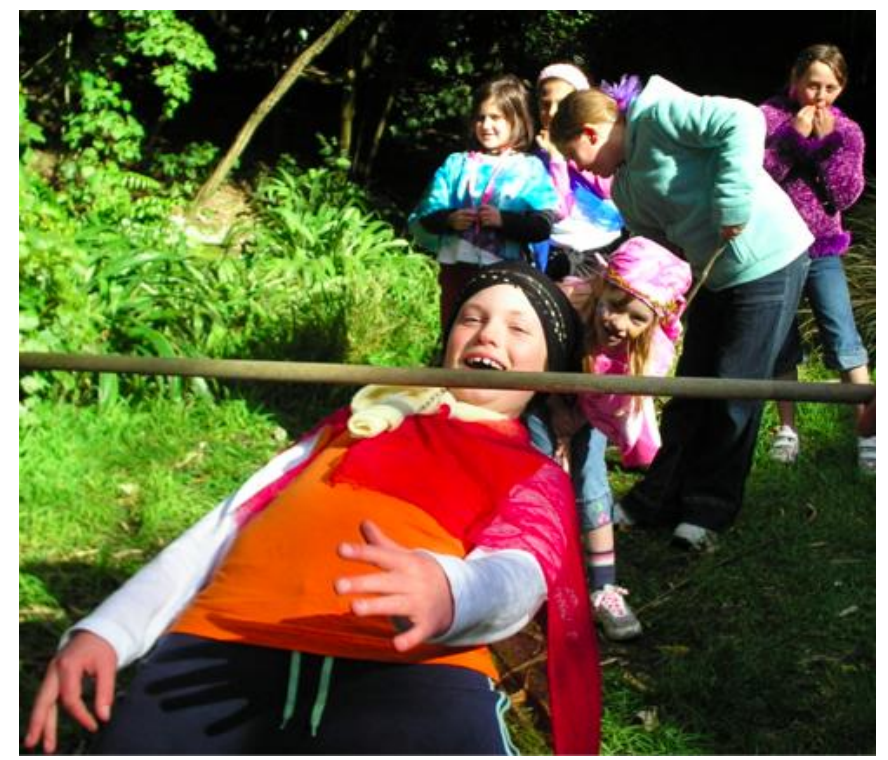

Figure 5: Image of me doing the Limbo at my friend's 8th birthday party at the Waimapihi Reserve.

A social constructivism understanding stipulates that knowledge is co-produced by the researcher and participant. Therefore, the researcher is not separate and objective; their experiences, aims, and interpretations inform the research process and output (Costantino, 2008). Acknowledging the subjective role of the researcher, how their identity and subjectivity influences the research process, can be addressed by exploring their positionality (Stroh, 2000). One's positionality includes, among other things: race, age, nationality, gender, and socio-economic status (Rose, 1997). Reflexivity is essential to exploring one's own positionality, and involves identifying the assumptions that underpin how research is conducted (Nicholls, 2009). There are two aspects to reflexivity: a critical 
introspection of the researcher's identity, and a self-conscious analytical scrutiny of the place of the researcher within the context of the research (England, 1994). However, one's positionality is not static, as one's identity is fluid and will change throughout the research process, and therefore, being reflexive involves reviewing one's positionality throughout the research process (Rose, 1997).

One aspect of the process is fieldwork, which is about personal interaction with participants, and therefore, acknowledging that aspects of the researcher's identity will influence the fieldwork is crucial for reflexivity (Nicholls, 2009). Additionally, reflexivity involves acknowledging and exploring the power of the researcher to make decisions about who participants are, what questions are asked, how responses are interpreted, and where and in what form the research is presented (Braun and Clark, 2006). Part of this is being transparent about the methods and circumstances surrounding data collection and analysis (Rose, 1997). However, recognising and acknowledging power relations that pervade personal beliefs and assumptions that influence the research does not remove them; if anything there is a risk that researchers can feel they have exposed and dealt with power relations because they have acknowledged them (England, 1994). To attend to these power relations the researcher must consider who the study is worthy or relevant for; what knowledge the community and the researcher will gain from the study, to whom the researcher is accountable, and what processes are in place to support the researcher and researched (Smith, 1999).

Some of the key aspects of my identity that I believe have influenced the research process include that I am Pākehā and I am a researcher in the academic setting. Being Pākehā meant I occupied a loaded place doing research on a waterway in Aotearoa-New Zealand. Pākehā researchers have spent centuries researching, collecting, classifying, and representing knowledge about Māori, and their land and taonga, as a colonial tool of control (Denzin and Lincoln, 2008). This work has neglected that Māori have their own ways of knowing and understanding waterways and that if research is to be undertaken on a waterway this knowledge cannot be ignored or forgotten. Therefore, any research on a waterway cannot be in isolation of its social and cultural history. Bearing this in mind, 
I attempted to be mindful of this context when I undertook my research, to understand that the Waimapihi is a taonga so must be treated with the utmost respect as well as the knowledge mana whenua hold about it.

Connecting to my identity as a Pākehā is my identity as a researcher in the academic setting, which is dominated by institutions that are founded on Eurocentric ideas of knowledge and knowledge production (Todd, 2016). An understanding of the power imbalances of research, particularly in the colonial context, is crucial in undertaking respectful research (Tuck and Yang, 2014). There are a range of researcher-participant interactions occurring during research that need to be considered. Firstly, the issue of mining the participants for information, which I tried to avoid by sharing knowledge both ways, providing them with anecdotes and understandings I had of the Waimapihi Stream (England, 1994). Secondly, my reliance as a researcher on the participants to provide knowledge for the research project, that this research could not have been conducted without them (England, 1994). Finally, my identity, as the researcher, influenced how I interacted with the various participants differently (Nicholls, 2009). The prior relationship I had with each participant influenced how much work was required to develop rapport. Changing a relationship from friend to researcher-participant changes the dynamic and must be considered. This was also the case with the Waimapihi Stream, my interaction with it has changed from one of childhood recreation to the subject of my research.

\subsection{My Struggle to Figure out a Methodological Approach Appropriate to the Context of the Research}

I faced a few conundrums deciding upon a methodological approach for this research that would align with my theoretical underpinnings and the context it was undertaken in. This section will trace my decision-making process, including the initial dilemmas I faced and 
my change of direction. It will investigate the more-than-human methodological approach I landed on, the limitations of that approach, and how I addressed these. This section highlights how methodological practices are never precise, fully knowable, or value-free, and transparency is required throughout the research process to acknowledge this and attend to it (Denzin and Lincoln, 2008).

\subsubsection{Initial Stumble into a Decolonising Methodology}

Initially, I thought using a decolonising methodology was essential because this research was on a waterway in Aotearoa-New Zealand, a colonial context. My thinking started with consideration of the ongoing settler colonialism occurring in Aotearoa-New Zealand. Settlers arrived and claimed land, deeming it their property to occupy or sell, removing it from local Māori. This changed the way land, and ownership of it, were understood from then onwards, making colonisation in Aotearoa-New Zealand a structure not just an isolated event (Tuck and Yang, 2014). The colonisation process in AotearoaNew Zealand has significantly impacted how the country is run, the environment is perceived, and research has been undertaken (Smith, 1999). Denzin and Lincoln (2008) suggest the modern Western academy has been a colonial tool; collecting, classifying, and disseminating Indigenous knowledge as a means of controlling and exploiting Indigenous peoples and their lands, and defining what knowledge is legitimate. While Smith (1999) writes that the Indigenous people of Aotearoa-New Zealand are tangata whenua, people of the land, which means that any work on the land, and its waterways, is work on them. Therefore, I felt only a decolonising methodological approach would enable me carry out my research respectfully, to acknowledge and confront the colonial ways this has been done before.

However, I felt unease at saying my work was decolonising, as I am Pākehā and I felt I did not have the right or ability to say what was decolonising or not. Decolonisation is a theory with a rich history of Indigenous scholars and activist work that has challenged power structures that exclude Indigenous peoples (Appleton, 2019). Having not been a 
part of either of these communities, I do not have the power or right to define my work as decolonising. Then with further research, I really started to think about what decolonising was, and Tuck and Yang's (2012) work made me realise that to decolonise requires going beyond words and intentions (and "decolonising the mind"), to actually repatriate Indigenous land and resources to Indigenous peoples, not something that my research does. Instead, while falling short of decolonisation, my research seeks to engage with ethics of respect and reciprocity.

As part of carrying out respectful research about a waterway in Aotearoa-New Zealand I wanted to talk to mana whenua through formal channels about the direction of my research. Taranaki Whānui ki Te Upoko o Te Ika (Taranaki Whānui) is the collective name of the mana whenua of Te Whanganui-a-Tara-Wellington, which includes: Te Ati Awa, Taranaki, Ngāti Tama, Ngāti Ruanui, and Ngāti Mutunga, who continue to live and maintain ahi kā in the region (Port Nicholson Block Settlement Trust, 2012a). Through my supervisor, I set up some meetings with Taranaki Whānui and Te Atiawa. Tipa (2009) emphasizes the importance of developing a respectful and reciprocal relationship with mana whenua when carrying out research on the land or water in their rohe. Pre-interview meetings were an attempt to respect the sovereignty of the mana whenua by ensuring they felt comfortable with the direction of the research, in an effort to do research with, rather than on, Māori and their land and water (Smith, 1999). However, most freshwater policy in Aotearoa-New Zealand now legally requires iwi consultation, so mana whenua are constantly asked to provide input and are stretched beyond capacity (Morning Report, 2020). Consequently, all the mana whenua groups we reached out to were too busy to talk to me, meaning my research is lacking a key component of specific formal mana whenua views on the Waimapihi, which is a real detriment to my research.

This experience taught me some valuable lessons about making claims about what your research does, such as to decolonise, and actually enacting your claims about how you conduct your research. Furthermore, it made me critical of my initial motives for talking to mana whenua. I realised I was seeking to use their words for my own benefit; to legitimise or authenticate my research, which is against the principles of decolonisation 
(Tuck and Yang, 2014). Therefore, I decided I would steer well clear of the term decolonising, as using it about this research does a disservice to the theory behind it, and would be a misrepresentation of what my research is achieving. This was reinforced by Appleton (2019) who suggested using the word decolonising was often merely an attempt to sound progressive, and Tuck and Yang (2012) who suggested overuse of the word decolonising was reducing its power. Therefore, I decided that having a refusal ethic, described by Tuck and Yang (2014), underlying my research was a more effective and realistic way of confronting the ongoing structural colonialism within academia and environmentalism.

A refusal ethic is based on the idea of humanising the researcher, that there are limits to what should be made public, what knowledge is up for discussion, what is sacred, and what cannot be known. This suggests that research be accountable to those researched, more so than the university, thus requiring personal accountability, caring, and empathy (Tuck and Yang, 2014). Denzin and Lincoln (2008) suggest that it is the role of nonIndigenous scholars, not just Indigenous peoples, to dismantle and decentre "traditional" ways of doing research. To achieve this inquiry should be redirected to explore otherwise unacknowledged or questioned ideas by turning the gaze back on power, the academy and institutions, to demonstrate that research is moral and political (Tuck and Yang, 2014). This involves recognising that there is a responsibility and consequences that accompany knowledge acquisition, including protection and appropriate use of knowledge, and a reciprocity, one must give back in return for the privilege of that knowledge (Kimmerer, 2012). Part of this is understanding that not everything said by participants needs to be presented in the final research output, as people's stories are their own and not freely available or owned by the researcher (Tuck and Yang, 2014). Using this refusal ethic went some way to appease my qualms about carrying out research on a waterway in Aotearoa-New Zealand. This enabled me to step back and consider the methodology that best suited my aims to explore the meanings of the Waimapihi Stream by examining the hydrosocial components that make it up. Therefore, the methodological approach that appeared to best fit this exploration of the components that make up the waterway was a more-than-human methodology, which brings together a range of perspectives including those of non-humans. 


\subsubsection{Deciding on a More-Than-Human Methodology, with Caveats}

I chose a more-than-human methodology because it goes some way to direct my thinking around the fluidity between nature and society that comes out of my hydrosocial cycle framework and social constructivist epistemology (Sundberg, 2014). It challenges dominant worldviews that humans shape the world around us and instead explores the role of non-humans, which has been ignored in much of the previous literature (Dowling, et al., 2017). This approach acknowledges the imperfect understanding and incomplete control humans have over nature, and the agency non-humans have in shaping the world and humans (Bakker, 2003). Agency is the power of an entity to produce a particular outcome, including to act upon or limit the actions of other entities. It has often been confined to humans, who express their agency through decision-making and behaviour (Thomas, 2015). However, the agency of non-humans can be conceived as the sets of relations that produce particular outcomes, encompassing more broadly the ability to shape the world, decentring it as a concept only for humans (McGregor, et al., 2019). This challenges the definition of agency, decoupling it from exclusively human characteristics to be reconceptualised as a spectrum of characteristics that differ depending on the entity (Thomas, 2015).

A more-than-human approach places human agency as one of many agencies, including that of the stream, fish, plants, pipes, technology, objects, and institutions, which interact in the production of meaning and place of the Waimapihi (Sundberg, 2014). Therefore, it embraces the messiness of the world that contains a range of entities with agency that are continually interacting (Dowling, et al., 2017). More-than-human approaches present a way to perceive society to include these human and non-human entities (Watts, 2013). Acknowledging this refashioned society challenges assumptions around the social and the social actor, to develop methods that are inclusive of non-humans (Buller, 2015). Therefore, it is an appropriate methodology to use to explore the agency of the multiple, 
interrelated human and non-human components involved production of the Waimapihi Stream.

However, more-than-human scholarship has been critiqued for perpetuating coloniality by privileging Anglo-European knowledges and appropriating Indigenous knowledges (Panelli, 2010). The theory has often been applied to 'modern' science and technology, making humans and their technology the focus which privileges only some, very humancentric, forms of human-non-human assemblages (Buller, 2015). Furthermore, it has been criticised for making universalising claims about entities, assemblages, or processes that disregard difference and worldviews other than Western (Sundberg, 2014). Many Indigenous cosmologies, which have been developing for millennia and are constantly evolving and negotiated, have been theorising a world where everything is interrelated (Todd, 2016). An example as described by Roberts, et al., (1995) is the Te Ao Māori understanding that all the entities in the world are connected, with no clear demarcation between supernatural, natural, and social. This connection engenders a sense of reciprocity and responsibility between humans and the surrounding environment. Within a Māori worldview all things are connected by whakapapa, through whanaungatanga; that everything descends from Papatūānuku and Ranginui. Therefore, people are a part of nature and there is no distinction between inanimate and animate beings (Tipa, 2009). However, this idea of a world beyond humans has only become fashionable and "legitimate" in academia since Western academics such as Latour have brought it into the mainstream, calling it more-than-human (Todd, 2016).

This 'new' more-than-human thinking is not new at all, Indigenous cultures all over the world have understood the world beyond humans; that humans are just a small part of a larger system where animals, water, the land, and non-human presences are sentient and possess agency to shape the world (Todd, 2016; Panelli, 2010). Roberts et al., (1995) discuss the risks of perpetuating colonial power relations when trying to learn from Indigenous worldviews. They suggest that one must engage with the Indigenous knowledge and understand the cultural context, not just 'cherry pick' the parts of it they like. This can be termed knowledge mining and refers to the extraction of useful facts 
from a body of knowledge without considering the cultural context from which they belong, which does a disservice to the information and the culture (Kimmerer, 2012). Watts (2013) agreed with this sentiment when discussing how many Indigenous cosmologies, and their complex theories, are not separate from place; that knowledge is not separated from its practice in the location. Therefore, I attempted to engage with the local understandings of the Waimapihi Stream, and freshwater, and consider the social, historical, and cultural context that this research is being undertaken in.

A more-than-human approach enabled consideration of the agency of the land to speak, create, and teach responsibilities that people have to it which encouraged land-based relationships and knowledge to be produced, which many Indigenous worldviews have embraced (Larsen and Johnson, 2016). Thomas (2015) suggested that more-than-human approaches could provide opportunities for non-Indigenous peoples to learn from Indigenous knowledges and skills and to develop a language to articulate their interactions with non-human entities. Therefore, as a Pākehā researcher using the morethan-human frameworks and language helped me to interact with and explore some Indigenous perspectives and ways of knowing about the Waimapihi without appropriating or being disrespectful (Sundberg, 2014). However, it was crucial that I did not try to use more-than-human theory to fit Indigenous ways of thinking into the Western academy, or to only incorporate the parts that I liked or made sense to me (Larsen and Johnson, 2016). It was used as a framework to articulate my perceptions and those opinions gleaned from the range of participants involved in the study. However, this illustrated the limitations of the more-than-human approach, primarily that it is a Western academic theory that has been appropriating and legitimising knowledges that have been held by many Indigenous communities for millennia (Sundberg, 2014; Todd, 2016; Panelli, 2010). I was cognisant of these limitations as I chose my methods for undertaking this research, and they informed the mixed, messy methods approach taken that attempted to incorporate the more-than-human, hydrosocial assemblage of the Waimapihi in the context of Te Whanganui-a-Tara-Wellington, Aotearoa-New Zealand. 


\subsection{Mixed, Messy Methods Approach}

Stemming from how I view knowledge as political, partial, and constructed, and that humans and non-humans have agency, the methods for this research are mixed and messy (Jungnickel and Hjorth, 2014). By mixed I mean I conducted semi-structured interviews which fall under the realm of qualitative methods, and I carried out fish spotlighting which falls under the realm of quantitative methods. By messy I mean I then combined the spotlighting results into my interviews, so they did not fit into the "traditional" categorisations of methods. Therefore, using this ambiguous term of mixed, messy methods was an attempt to acknowledge that the world is messy and hard to define, meaning the methods used to explore it cannot be neatly defined (Buller, 2015; Dowling, et al., 2017). Furthermore, employing mixed, messy methods recognises that producing knowledge is a messy endeavour, and therefore, the methods used require more creativity to capture this mess (Jungnickel and Hjorth, 2014). Despite making attempts to make my research prioritise my participants, my research was also bound by the constraints of undertaking Masters level research at a university as there are accountabilities of working within the university institution (Jungnickel and Hjorth, 2014). Universities require particular outcomes, i.e. a thesis, in order to comply with established frameworks, so the data produced was still textual data to analyse and draw themes from to explore and write chapters on (Jungnickel and Hjorth, 2014). This section will explain how I carried out these methods and how they align with my theoretical underpinnings.

The first method was fish spotlighting in the open headwaters of the Waimapihi Stream, to explore the fish life in the stream. This was part of my more-than-human approach to examine a non-human perspective of the stream. Spotlighting is a method for sampling fish that comes under the 'New Zealand Freshwater Fish Sampling Protocols' (Joy, et al., 2013). Fish spotlighting procedure involves walking along the length of the stream at night and shining a torch into the stream to identify and count fish seen. Indigenous freshwater fish in Aotearoa-New Zealand tend to be nocturnal, meaning spotlighting is an effective method to see these fish in wadeable streams, such as the Waimapihi. Spotlighting is a rapid sampling method, that is non-invasive to the fish, and requires little 
equipment. This method determines the presence of Indigenous fish, in contrast to a comprehensive survey which would involve trapping every fish and measuring their length. One of my supervisors is an experienced freshwater ecologist, and so with his knowledge we were able to identify the species present in the Waimapihi. After gaining animal ethics approval, two spotlighting expeditions were carried out on the evenings of 11th July and 12th November 2019, to corroborate the findings between the evenings and over two seasons. Each time we walked up the stream for approximately 500 metres whilst panning the spotlight across the stream and identifying freshwater species. Images were captured of some of the fish seen to document the species we saw.

The second method was semi-structured interviews, eleven of which were undertaken after receiving human ethics, between July and September of 2019. The interviews loosely followed an interview schedule (Appendix E) to ensure all topics were covered and participants were given space to discuss their opinions on the Waimapihi. The focus was on people's different experiences and feelings about different aspects of the stream, moving from the open headwaters, to the piped section, and the outfall into the Harbour. Then participants were asked whether the presence of fish influenced how they viewed the Waimapihi, both headwaters and pipe, and how they defined a stream. The interviews varied depending on the experience of the participant, where they worked, where they lived, or their relationship to the stream. The interviews were conversational in nature, including open-ended questions for participants to explore their attitudes and to construct meanings of the Waimapihi, and me sharing of my own experiences of the Waimapihi, rather than just mining the participants for knowledge (Stroh, 2000). This was an attempt to have more of a reciprocal relationship with the participants to try to produce knowledge about the Waimapihi together (Smith, 1999).

How these methods were incorporated together is what makes them mixed and messy. The goal of combining the two methods of spotlighting and semi-structured interviews was to explore the role and agency of the stream, infrastructure, and the fish in defining urban streams and their place in cities. These methods were combined because I believe "traditional" methods often fail to consider the complicated interactions humans have 
with non-humans, or to give a voice to non-humans (Junknickel and Hjorth, 2014; Dowling, et al., 2017). The fish species spotted were discussed in interviews, and participants with ecological knowledge compared what we had seen with their knowledge of the Waimapihi from their work around it. This referral back and forth between the methods is part of what makes them mixed and messy. Additionally, during the interviews, I showed the participants the photographs taken during the spotlighting to explore the presence of fish in the Waimapihi with participants in the interview. "Traditional" interview techniques can be enhanced by visual methods to capture more detail and different types of data (Glaw, et al., 2017). Using photos in interviews is called photo elicitation, and it is used to add another layer to the interview to produce greater richness and depth in data (Glaw, et al., 2017). People react to images differently than to words, and therefore, this results in more variety in the data produced. This reaction can be immediate or can result from deliberation over the image, where the participant takes time to process their response as they examine the image, which can often lead to a more well thought out response (Glaw, et al., 2017). Furthermore, infusing the interviews with images of the fish we had spotted in the stream made them seem more real, and encouraged the participants to understand them as an individual they could interact with and develop meaning from (Buller, 2015).

\subsubsection{The Participants}

Eleven interview participants (table 1) were chosen, either because of their proximity to the stream or because their work was directly related to it. Some were spatially chosen, with the goal to interview residents near the open section, owners of shops above the piped section, and artists of works over the piped section. In addition, participants with a relationship to the stream through work at the councils or Wellington Water (WW) were chosen. The sampling for this study was concerned with information richness rather than representation, which requires appropriateness and adequacy of participants chosen to be assessed. An appropriate participant is one who can best inform the study, while adequacy of participants stipulates that there is a relevant range of participants to address the research question and explore the topic of research properly (Fossey, et al., 2002). To an 
extent this was achieved, and interviews were conducted with a range of people who had various connections to the Waimapihi Stream, but the lack of mana whenua through formal channels leaves a significant hole. However, I did talk to three Māori participants, one resident of Holloway Road, and the artists (or relative of) whose works both engaged with the Waimapihi informed by their identity as Māori. Their iwi connections are shown in table 1. Ra said he had whānau connections to the mana whenua of the Waimapihi but that his hapū came from Paraparaumu. The sample was assessed throughout the process, checking that I had sufficient breadth and depth; once saturation occurred and no new information was emerging, I stopped interviews and in the end eleven were undertaken (Fossey, et al., 2002). First names of the participants have been used in the thesis, except for three participants who asked to have their names kept confidential, so they were given pseudonyms. The recruitment process used a mixture of past connections and sending out emails, and then snowballing to find more people from the initial connections made. I interacted with a wide range of people, including council workers, artists, residents, and business owners, and I spanned an age range from early twenties to mid-eighties, which influenced the interview approach, where it took place, and the formality of the process. 
Table 1: List of participants and their relationship to the Waimapihi Stream.

\begin{tabular}{|l|l|l|}
\hline Name & Role & $\begin{array}{l}\text { Location along or } \\
\text { Interaction with Stream }\end{array}$ \\
\hline Frances & Holloway Road Resident & $\begin{array}{l}\text { Lives near open section at Waimapihi } \\
\text { Reserve }\end{array}$ \\
\hline $\begin{array}{l}\text { Lily (Ngāpuhi and Ngāti Kahu on } \\
\text { father's side) }\end{array}$ & Holloway Road Resident & $\begin{array}{l}\text { Lived near open section at Waimapihi } \\
\text { Reserve }\end{array}$ \\
\hline Phill & $\begin{array}{l}\text { GWRC Policy Analyst and Former } \\
\text { Resident of Aro Street }\end{array}$ & $\begin{array}{l}\text { Lived near open section at Waimapihi } \\
\text { Reserve and works on freshwater in } \\
\text { local government }\end{array}$ \\
\hline Bob & $\begin{array}{l}\text { GWRC Senior Environmental } \\
\text { Scientist }\end{array}$ & $\begin{array}{l}\text { Works on freshwater in local } \\
\text { government }\end{array}$ \\
\hline Myfanwy & WCC Head Ecology Team & $\begin{array}{l}\text { Works on freshwater in local } \\
\text { government }\end{array}$ \\
\hline Ben & Ww Chief Advisor: Stormwater & $\begin{array}{l}\text { Works on freshwater in government } \\
\text { owned organisation }\end{array}$ \\
\hline $\begin{array}{l}\text { Ra (Te Atiawa descent with hapū } \\
\text { from Paraparaumu) }\end{array}$ & Artist of Z Energy Sculpture & Art over piped section \\
\hline $\begin{array}{l}\text { Rachel (Ngāti Awa Ki Aotea on } \\
\text { mother's side and Te Arawa from } \\
\text { Motiti on father's side) }\end{array}$ & Relative of Artist of Te Aro Park & Art over piped section \\
\hline Christina & Owner of Hunters and Collectors & Owner of shop over piped section \\
\hline Ian & Owner of Mark Kendall Shoes & Owner of shop over piped section \\
\hline Sandra & Owner of Pizza Pomodoro & Owner of shop over piped section \\
\hline
\end{tabular}

\subsection{Thematic Analysis}

Translating messy oral conversations to neat typed transcripts is value laden because the researcher has control to choose what is included in the transcript (Junknickel and Hjorth, 2014). Therefore, I decided to transcribe verbatim to ensure the participants' own words were used in the analysis, so audio recordings were made of the interviews to aid this verbatim transcription. Minimal editing of transcripts occurred to remove words such as 'um' and 'like', that do not alter meaning, to make the participants feel more comfortable with the final product. The transcription process was the first stage of analysis as it required close attention to produce the transcripts, which would then go on to be analysed (Braun and Clark, 2006). 
Thematic analysis was undertaken on the interview transcripts, which involved reading and re-reading to become familiar with them and uncover the emerging themes (Braun and Clark, 2006). A manual coding system was used to label segments of data with the various identified themes. These segments were then moved around and brought together to explore the patterns, connections, or distinctions between themes (Fossey, et al., 2002). I chose to carry out manual coding as it allowed me to engage with the data and explore the nuance and meaning that could have been missed doing automated coding. Furthermore, manual coding allowed connections to be made across the data at different scales, from individual comments by participants, to their overall interview, to comments made by multiple participants or groups of participants, to the entire data set (Stroh, 2000). This iterative process of reviewing the transcripts led to the separation of the data and analysis into two main sections: present and future perceptions of the Waimapihi. People's present perceptions of the stream described their views on the issues and encouraging aspects of the Waimapihi in its current state. The future perceptions of the stream described the ways people wanted or expected the stream to be like in the future. Once the data was split into the two timeframes, different groupings within each timeframe were identified, figure 6. This led to the classification of three main themes: phases of the Waimapihi, fish in the Waimapihi, and people's connection to piped section. Within the three main themes there were sub-themes seen in figure 7. 


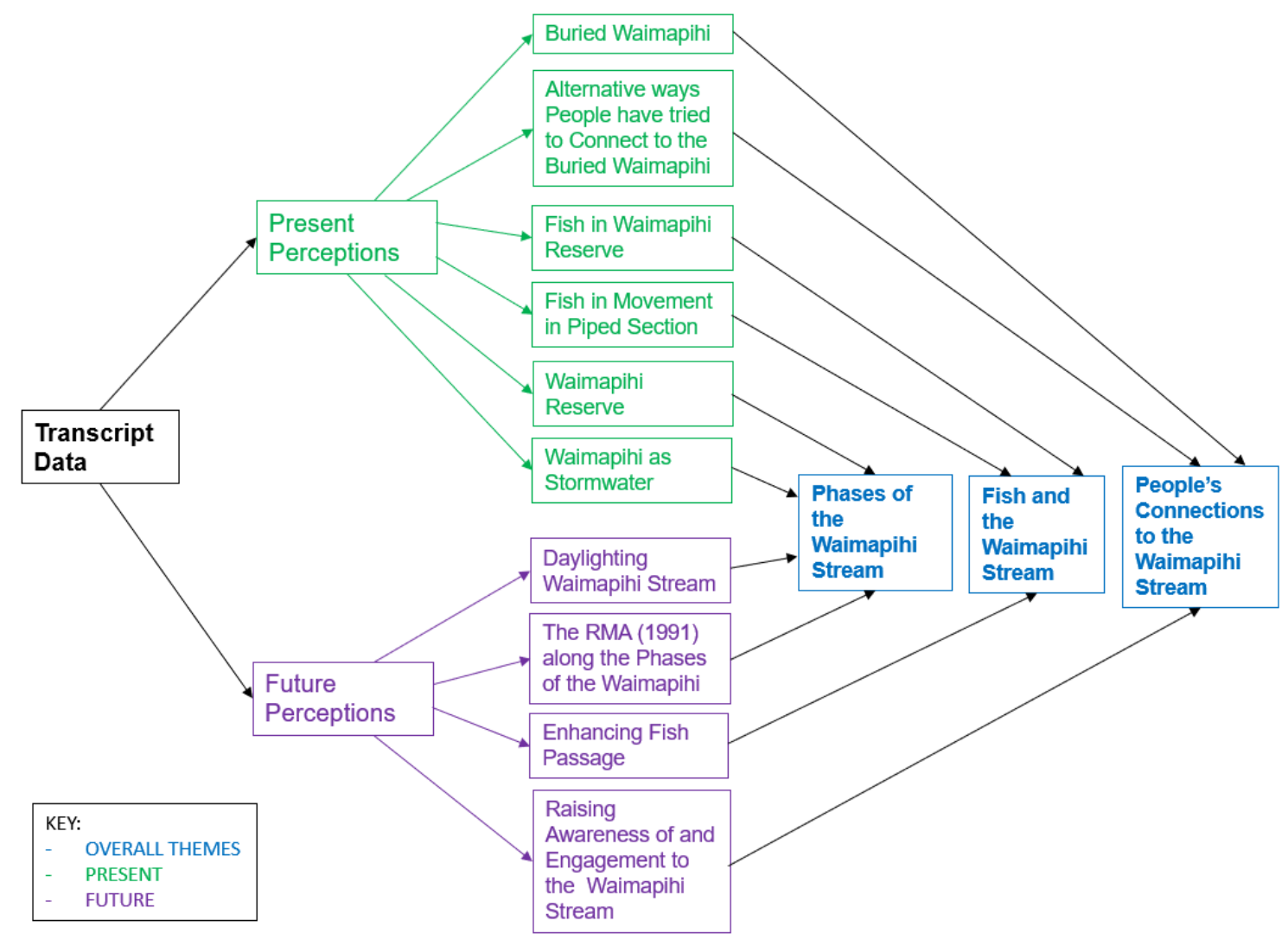

Figure 6: Analysis process to determine the overall themes.
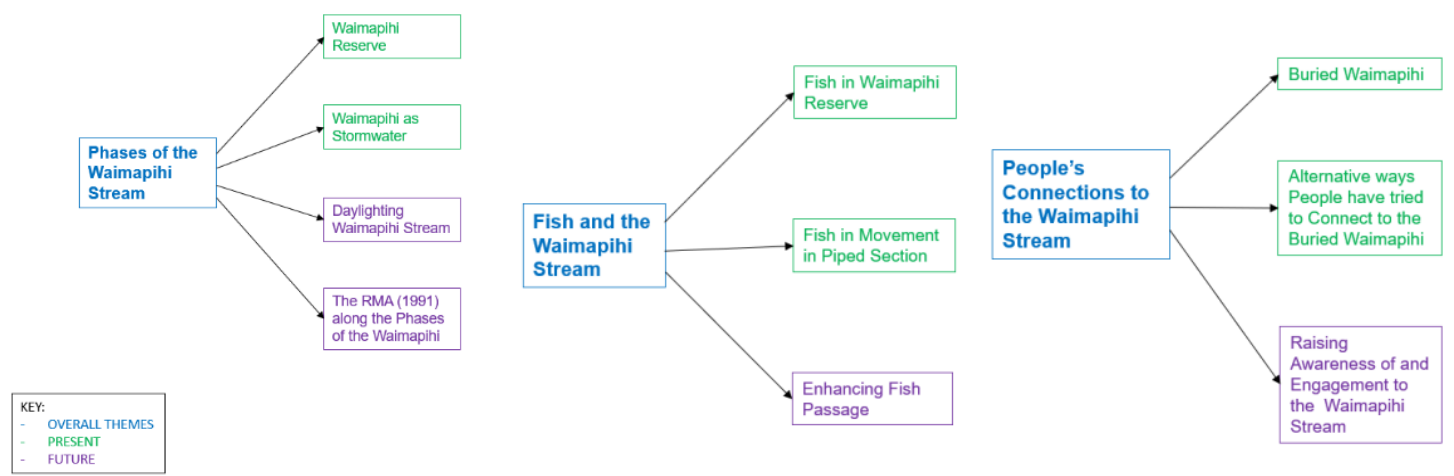

Figure 7: Overall themes and sub-themes.

In the writing process of the final thesis, quotations of participant's own words were chosen to include as examples of my findings. A significant number of quotations from the interviews were included so that the participants voices could drive the direction of 
my discussions, because the aim of this research was to represent the subjective meanings, and people's lived experiences and perceptions, of the Waimapihi Stream. These quotations of participants words were juxtaposed with my descriptions and interpretations as the researcher, to enable the reader to evaluate the authenticity of my claims about the data (Fossey, et al., 2002).

\subsection{Conclusions}

The hydrosocial cycle was the theoretical framework chosen and informed how I conducted this research, and therefore, drove the methodological choices I made. Water flow; social structure, power, and institutions; and technology and infrastructure, all interact in the hydrosocial cycle to produce the Waimapihi. Therefore, it is a good framework to explore some of the issues around buried streams that can be forgotten with other approaches. After an initial false start, I arrived at more-than-human as my methodology, which enabled exploration the agency of the various components of the hydrosocial cycle, including the non-humans such as fish and pipes. An acknowledgement of the critique of this methodology, that it has taken from Indigenous cosmologies was included, to ensure these limitations of the methodology are considered during its use. This chapter described how these theoretical considerations influenced the methods I chose to produce data that had appropriate breadth and depth to explore the meanings held around the Waimapihi Stream. The remainder of this thesis examines the themes that were identified through the inductive and iterative process of analysis undertaken. 


\section{Chapter Four: Spatial and \\ Temporal Phases of the}

\section{Waimapihi}

\subsection{Introduction}

Streams are in constant flux, with fluctuating water flow and quality, presence of species, morphology, and path (Lavau, 2013). Stream meanings are produced through flow rates, sediment types and transport, rainfall, vegetation, fish, infrastructure, and activities of people (amongst many other things). Perceptions of urban water and streams vary and emerge from particular amalgamations of practices, technologies, stories of cities, and stream and stormwater management. The definition of a stream or river can be viewed from a variety of perspectives, including ecological, legal, personal, technical, cultural, political, and economic; and the one used in policy has important and ongoing implications for its management (Gibbs, 2009). Most rural streams have open, meandering water flow through vegetation, compared to urban streams that can instead take many different forms (Paul and Meyer, 2001). This exemplifies the limitations of considering nature and society (and nature and urban) to be separate rather than on a continuum (Swyngedouw, 2006). The process of urbanisation has changed the form of the land and water, while simultaneously the land and water has changed the form of cities (Swyngedouw, 1996). This chapter explores the complexity of an urban stream, the Waimapihi, by examining some of its spatial and temporal phases.

The three main phases of the stream include: the headwaters at the Waimapihi Reserve, the stormwater piped section, and then potential changes into the future of daylighting the 
piped section. They reflect a spatial movement down the stream from the headwaters to the Harbour. The phases also reflect temporal changes, within each phase there are aspects that reflect different states of the Waimapihi (past, present, and future); however, none of them are fixed demonstrating the fluidity of time. Having these diverse phases contributes to what makes urban streams different to rural or "natural" streams, alongside the impacts of the modified surrounding landscape, making them a more complex management challenge (Paul and Meyer, 2001). A part of this is the complexity and confusion around the different laws and policies that cover the different phases of urban streams, which tend to be more disjointed than those governing continuously open flowing rural or "natural" streams.

This chapter will begin with an examination of how urbanisation has changed and been influenced by water. I will then explore the three phases of the Waimapihi, with a focus on the flow of water, the infrastructure through which it flows, and social power and legislations (specifically the RMA (1991)) that governs the direction, rate, and quality of the flow. I will highlight how this complexity can be captured by taking a hydrosocial lens to investigate the Waimapihi Stream. The hydrosocial cycle approach will enable me to examine not just the flow of water, but the infrastructure it flows through, and the social power and institutions that control where the water flows, what goes into it, and the interactions different entities have with it.

\subsection{Urbanisation and the Control of Water}

Urban is often perceived as the opposite of nature, distinct and separate from it; similar to the nature-society dualism that has permeated Western science, and much of the accepted understandings of the world (Swyngedouw and Kaïka, 2002). Perceptions of nature centre on "pristine" and green land, not tainted by humans, that is inherently good. Conversely, ideas around dirtiness and immorality emerge around cities, that could be sanitised by the introduction of green space. However, there is nothing unnatural about produced environments, such as urban areas. They are merely the result of 
transformations of physical, chemical, and biological components of the environment that occurred in specific historical, social, cultural, political, and economic conditions, and fluctuate over space and time (Swyngedouw, et al., 2002). Cities are neither purely social or natural, or non-social or non-natural, they are socio-natural entities that embody and mediate social and natural processes (Swyngedouw, 1996).

Humans have generally settled near waterways as they provided access, transportation, a means to remove waste, and a source of water (Napieralski and Welsh, 2016). However, these waterways that were once essential, became a nuisance as cities developed and encroached on them, causing flooding impacts to be more severe (Swyndegouw, 1996). Flooding influenced the development of infrastructure to control water circulation and its variability over space and time (Gandy, 2004). Infrastructure was used to try force waterways to fit into the patterns of urbanisation, which in turn shaped city structures (Kaïka and Swyngedouw, 2000). The urbanisation process is predicated on organising, capturing, controlling, and engineering the circulation of water flow (Gandy, 2004). However, this process is not static, urban expansion was accompanied by increased use of and exploitation of water which significantly changed urban water circulation (Swyngedouw, et al., 2002).

One hegemonic ideology amongst most Western societies is a need to 'conquer' nature, including water, through development and modernisation (Allon and Soufoulis, 2006). People strive to modernise water through the development of dams, channelled rivers, piped streams, and water supply networks, which simultaneously changes hydraulic processes and social relations (Linton and Budds, 2014). In cities there has been an endeavour to control and transform water, to provide continuous supplies of relatively high-quality water across cities (Bakker, 2012). Urban water networks become immanent and invisible, water flows through pipes and taps to enter our lives from nowhere in particular and everywhere (Kaïka and Swyngedouw, 2000). However, urbanisation has also strived to eliminate water from other parts of the city, through draining and piping, to aid development (Gandy, 2004). Extensive stormwater networks connected to urban streams underlie urban areas around the world (Elmore and Kaushal, 2008). These 
combinations of open and piped waterways produce urban water (Swyngedouw, 1996). New urban ecosystems have emerged from this urban water, which have redefined the meanings and definitions of waterways (Swyngedouw, 2006). The control of where water flows and is eliminated from is a political struggle, that has led to uneven and exclusive structures and processes that affect people's access to water across and between cities (Swyngedouw, 1996). The distribution and provision of technology, infrastructure, and services it supplies is heavily power-laden, it tends to benefit those in power and disadvantage the marginalised (Kaïka and Swyngedouw, 2000).

The process of urbanisation has degraded freshwater globally, in particular through modification, including channelling (specifically straightening and narrowing) and piping underground. The process of stream burial involves directing stream flow into culverts, pipes, or concrete-lined ditches, or simply paving over them (Elmore and Kaushal, 2008). Stream burial has removed waterways from the urban landscape; with the goals of improving sanitation, managing flooding, and providing a flat building surface for the city (Walsh, et al., 2005). Sanitation has been an issue for urban waterways around the world because they have been the dumping ground of waste, including sewage, leading to outbreak of diseases, such as cholera, and death (Gandy, 2004). These issues around the health of city residents influenced the burial of waterways, to disconnect them from the public, to control disease.

Impervious surfaces predominate in urban areas, rain falls on them and flows rapidly overland as stormwater runoff and into stormwater pipes straight to urban streams. Streams were combined with stormwater networks when they are buried in pipes, which has impacted on their hydraulic patterns. Stormwater influxes have increased the hydrologic connectivity, flashiness, flood frequency, and intensity of stream flow (Napieralski and Welsh, 2016). These changes in flow patterns combined with destruction of natural stream channels has altered ecosystem structure and function. Specifically, fragmenting aquatic habitats, reducing species dispersal and colonisation, and enhancing transport of water, sediment, and toxic contaminants (Elmore and Kaushal, 2008). 
Additionally, stream burial transfers streams into dark conditions which reduces sunlight, impacting on plant growth and altering thermal regimes (Elmore and Kaushal, 2008).

Urban streams are significant due to their role as ecosystems, their aesthetic, spiritual, and recreational value, and civil functions (Napieralski and Welsh, 2016). Small streams contain diverse species of fish, invertebrates, and algae; however, habitat quality can be highly sensitive to urban land use impacts (Elmore and Kaushal, 2008). The main impact is increased impervious surfaces causing stormwater to flow straight into streams, without treatment, resulting in influxes of contaminants and more frequent runoff events that disturb ecosystems (Hatt, et al., 2004). These urban contaminants are non-point source, meaning they do not come from a single source, making them much harder to control (Cousins, 2017b). Urban streams tend to have elevated concentrations of contaminants including heavy metals, polyaromatic hydrocarbons, and pesticides. Heavy metals can accumulate in sediment, plant, and animal tissue at levels toxic to freshwater life, and sometimes humans if bioaccumulation occurs (Hatt, et al., 2004). The concrete pipes the streams flow through are also a source of contaminants, as they are leaching minerals into the water changing its chemistry (Wright, Davies, Findlay, and Jonasson, 2011). Wright et al. (2011) found that urban streams tended to have a neutral $\mathrm{pH}$ due to elevated levels of bicarbonate and calcium concentrations, compared to rural streams which tend to be acidic. This range of contaminants, at these levels, are unique to urban areas and thus provide a new management challenge compared to that of rural waterways. The result of these cumulative impacts is degraded urban streams, that are not resilient to extreme weather events and have reduced biotic richness (Walsh, et al., 2005). Consequently, urban streams are more variable and complex than rural streams, therefore frameworks for understanding urban streams must encompass more range. The hydrosocial cycle provides a framework to examine this complexity that is inherent in urban streams. The Waimapihi is used as an example to demonstrate the benefits of a hydrosocial approach for examining urban streams, firstly by exploring the various phases of the stream. 


\subsection{The Waimapihi Stream in the Waimapihi Reserve}

This section examines the first phase of the Waimapihi Stream: the headwaters in Waimapihi Reserve, located above the top of Holloway Road, in Aro Valley. This phase is spatially the furthest upstream, and it demonstrates temporal changes in the stream, reflecting the past form of the Waimapihi but also how much it has changed since precolonial times. This phase is the only open section of the stream, flowing through native bush, taking the form of what a stream is often considered to be (top left in figure 8). The upper section of the headwaters provides a stark contrast to the central city, mere kilometres away. Ra, the artist of the Z Energy sculpture, suggested that the reserve showed what pre-colonial Te Whanganui-a-Tara-Wellington might have been like when he said "the Waimapihi, the source is, where the source, the part above the culvert section is really beautiful. I mean it is the only hint at kind of what pre-colonial Wellington may have been like, just a little hint" (Interview with Ra, 23 July 2019). Considering these changes through time when examining the open section of the Waimapihi demonstrates how much the rest of the stream, including the lower open headwaters, has been modified. The juxtaposition of the open flowing upper headwaters and the highly modified lower headwaters demonstrates the extent that the Waimapihi has been modified, even within the open section (figure 8). The point of transition from the open to piped section provides a stark example of the attempts to control water, with the use of a wall and cage to direct the flow of water and control what enters the pipe (bottom of figure 8). These structures also suggest the power and strength of water, that these cages and walls are necessary to protect the infrastructure from any damage the water being directed into it could cause. Schmidt (2014) echoed this idea of the strength of water, discussing how water is one of the main forces that shape landscapes, and therefore, have immense power. 

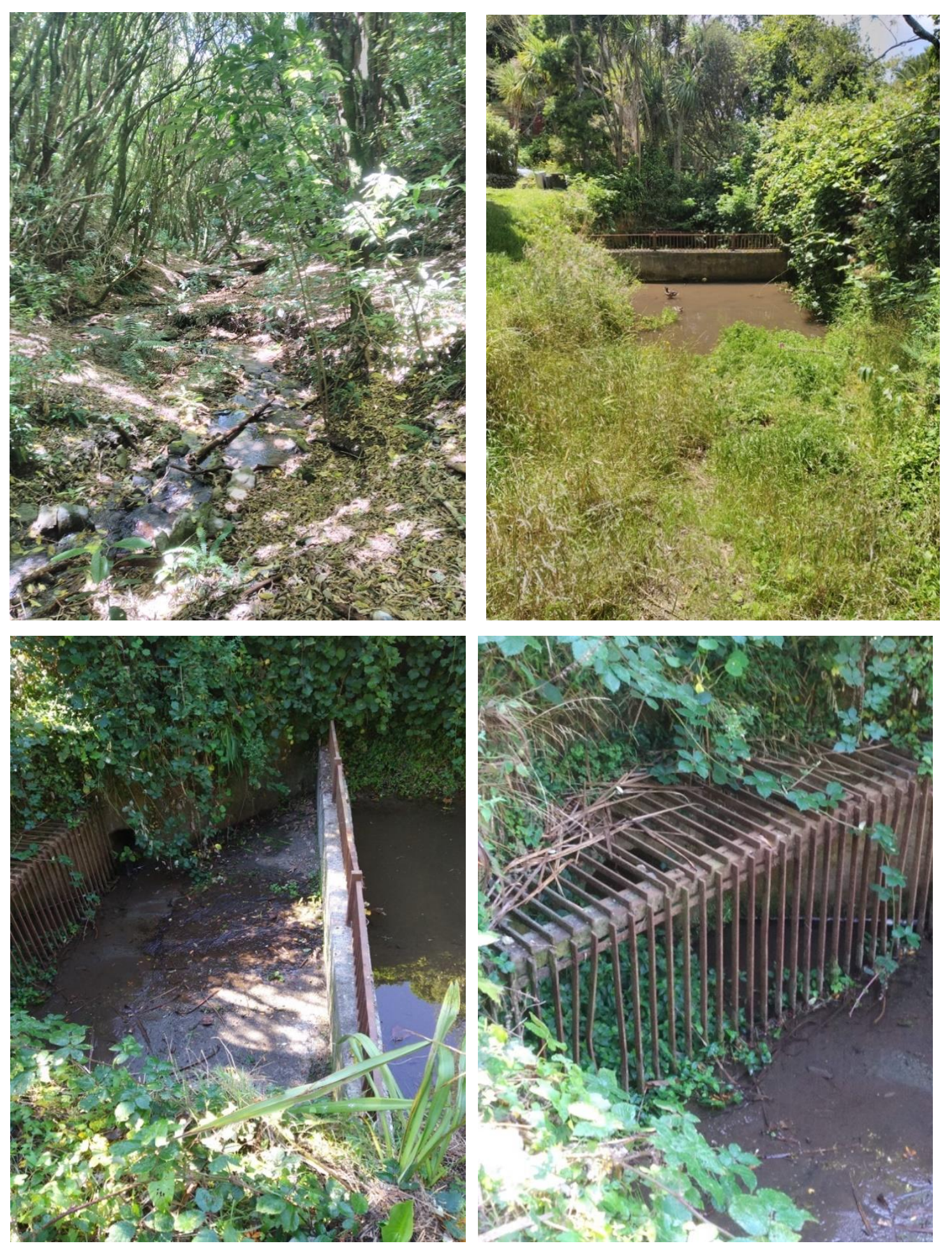

Figure 8: Images of the headwaters of the Waimapihi Stream, in Waimapihi Reserve. Top left: open flowing section. Top right: pooling before entering pipe. Bottom left: wall between pool and pipe entrance. Bottom right: cage covering entrance to pipe. 
The Waimapihi Reserve was classified as a reserve in 1989, this meant it was protected under the Reserves Act (1977) which prevented development of the area (Brassell, 2014). However, in 2016 the Waimapihi Reserve, which is within the Town Belt (figure 9), was no longer governed by the Reserves Act (1977) and is instead governed by the Wellington Town Belt Act (2016) (Wellington Town Belt Act, 2016). The Town Belt was set aside in the 1840 plan of Te Whanganui-a-Tara-Wellington by the NZC Surveyor William Mein Smith, to separate the 'Town' from the 'Country', under the instruction of NZC secretary John Ward (Raukura Consultants, 2016). The Town Belt was declared a reserve, making it public property for the utility of the city and its inhabitants, that no one could build on, clear, fence, or cultivate. The Town Belt was vested to Wellington City Council (WCC) in 1873, since then it has been owned by WCC on behalf of inhabitants of the city, who have full access to the land (Raukura Consultants, 2016). The Waitangi Tribunal found the deed of purchase for the land set aside for the Town Belt to be invalid, that land was taken off local iwi with no consultation or compensation for their loss (Raukura Consultants, 2016). The Wellington Town Belt Act (2016) puts protections on the Indigenous ecosystems in the reserve, open access to the public for recreation, and historic heritage of the reserve (Wellington Town Belt Act, 2016). Bob, from Greater Wellington Regional Council (GWRC), stated the implication of this protection, that under the RMA "you want to maintain the condition or improve it up in the headwaters, that's just nonnegotiable, that's in law, it's a reserve so it shouldn't get touched" (Interview with Bob, 18 July 2019). The legal implication of this reserve status is the stream cannot be modified in the Waimapihi Reserve, water cannot be abstracted, and pollution cannot enter the headwaters. Furthermore, the fish life in the stream is protected. Therefore, this reserve status influences how people use and interact with the land, the Waimapihi, and the fish life within the stream. 


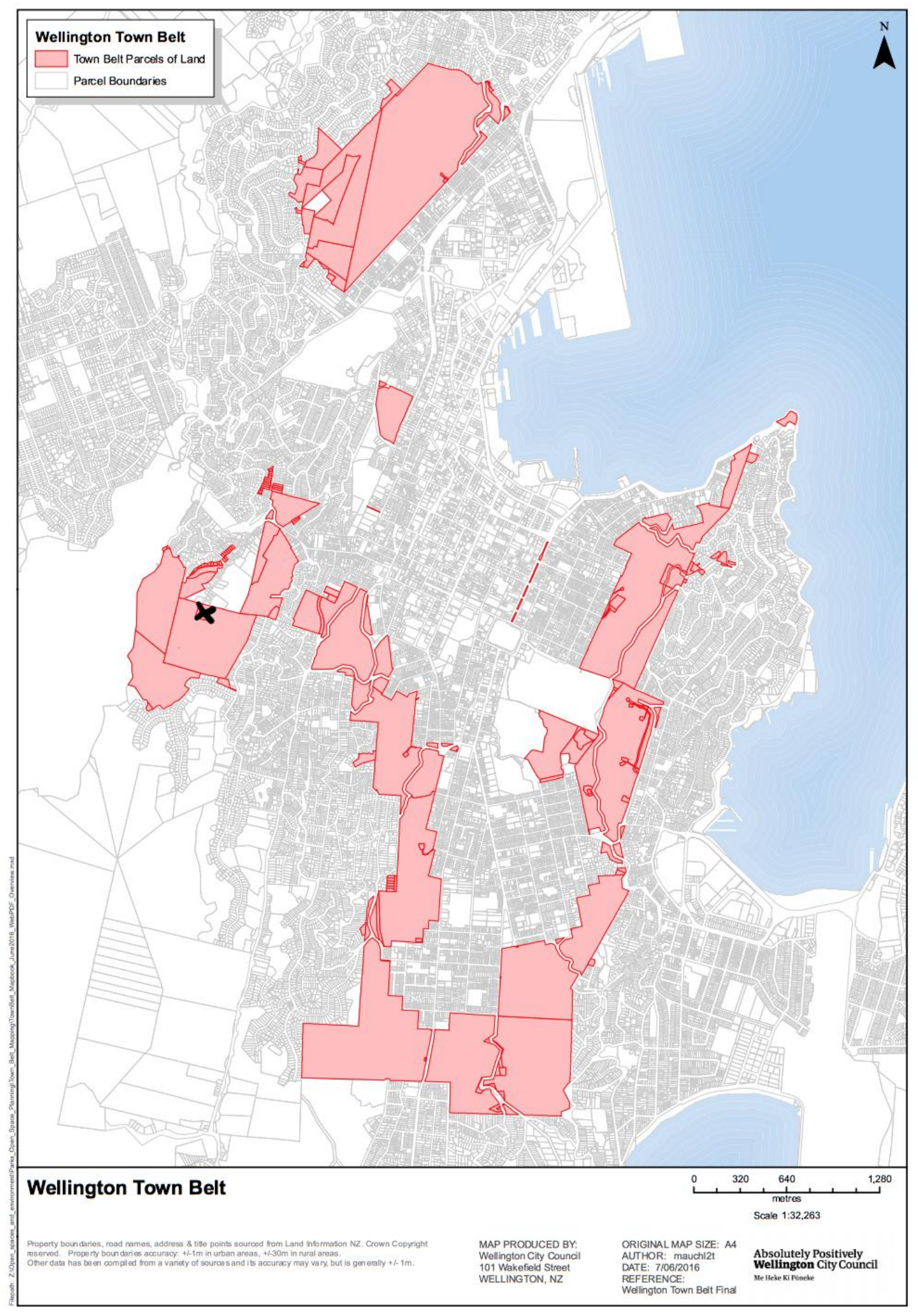

Figure 9: Map of Wellington Town Belt, Waimapihi Reserve indicated in black cross. Adapted from Wellington Town Belt overview map June 2016, WCC (2016), Retrieved from: https://wellington.govt.nz/ /media/recreation/parksand-reserves/files/townbelt-mapbook-june2016-web-overview.pdf?la=en 
One of the principles of the Wellington Town Belt is it "should be available for a wide range of recreational activities" (Wellington Town Belt Act 2016, 1bV). The Waimapihi Reserve is some of the most central greenspace in the city, providing recreational opportunities for surrounding communities. Urban streams can provide some of the most diverse greenspaces, containing an array of ecosystems that are easily accessible to city residents (Paul and Meyer, 2001). Many of the participants remarked how special it was to have this native forest greenspace and stream so close to the central city. Christina, owner of Hunters and Collectors, said "it's quite amazing having something like that in the city, you know where you can feel like you are immersed in nature, but you are actually only a few minutes away from the city centre" (Interview with Christina, 26 August 2019). This demonstrates the value of Waimapihi in the reserve to inner city residents, that native bush and streams are an important component of cities and their identity (Napieralski and Welsh, 2016). Furthermore, urban streams have been noted as an important educational opportunity for urban children to learn about stream ecosystems and the impacts of urbanisation on them (Paul and Meyer, 2001). Frances, a resident of Holloway Road, told me a story about how the stream had been a key place for recreation for children in Aro Valley.

Last summer they built a swimming hole in it, a really big swimming hole in it, behind the weir, that even had special steps with a landing on it to get in and out safely, and a handrail. And it may happen again this summer who knows, it's quite easy to do. There's a big dam and it's got little round pipes in the bottom and that's where fish pass through on their migration upstream. But then when the migration is finished in January they just put a couple of big plastic paint pot lids over those holes on the inside with a couple of rocks, and then the water pressure holds it in place and it fills right up to the top of the concrete, and you've got this little swimming hole. Oh yeah, it's lovely to see people walking up the street with the swimming towel over their shoulder and their swimsuit and things on. So I just feel incredibly happy, I feel really happy with Waimapihi full stop, but when I get in the stream or I am walking by the stream it's just brilliant (Interview with Frances, 25 July 2019). 
This highlights how understanding the interactions people have with the materiality of water, particularly immersion of bodies, are important for trying to understand the meanings of the Waimapihi (Linton and Budds, 2014). The headwaters in the reserve are important for how the Waimapihi is understood as a whole. It suggests what the stream looked like in the past and how much it has changed, and it is the only part of the stream where people are able to interact with the material flow of the water and the fish life within it, to inform their perceptions of it.

\subsection{The Waimapihi as Stormwater}

Below the Waimapihi Reserve the Waimapihi Stream enters the infrastructure of Te Aro Culvert, henceforth the pipe, through which it flows under the city. The pipe is connected to the stormwater system of Aro Valley, Te Aro, and the central city (figure 10). Stormwater comprises the runoff from all impervious surfaces in the city, into gutters down stormwater drains into pipes and out to the receiving waterbody, in this case Te Whanganui-a-Tara-Wellington Harbour (Walsh, et al., 2015). The goal of stormwater is to remove "excess" water from the city, as quickly as possible, which is required because the city structure has altered and disrupted the physical processes that previously mediated water flow (Cousins, 2017b). These physical processes include infiltration into soil and runoff into streams, but urban streams tend to be buried and flow through stormwater pipes; presenting a complex freshwater management challenge for cities (Cousins, 2017a). This section examines the stormwater phase of the Waimapihi Stream: looking at the power and institutions that govern and control the definitions, perceptions, and management of stormwater, and the role of the pipe in defining and producing this phase of the Waimapihi as stormwater. 


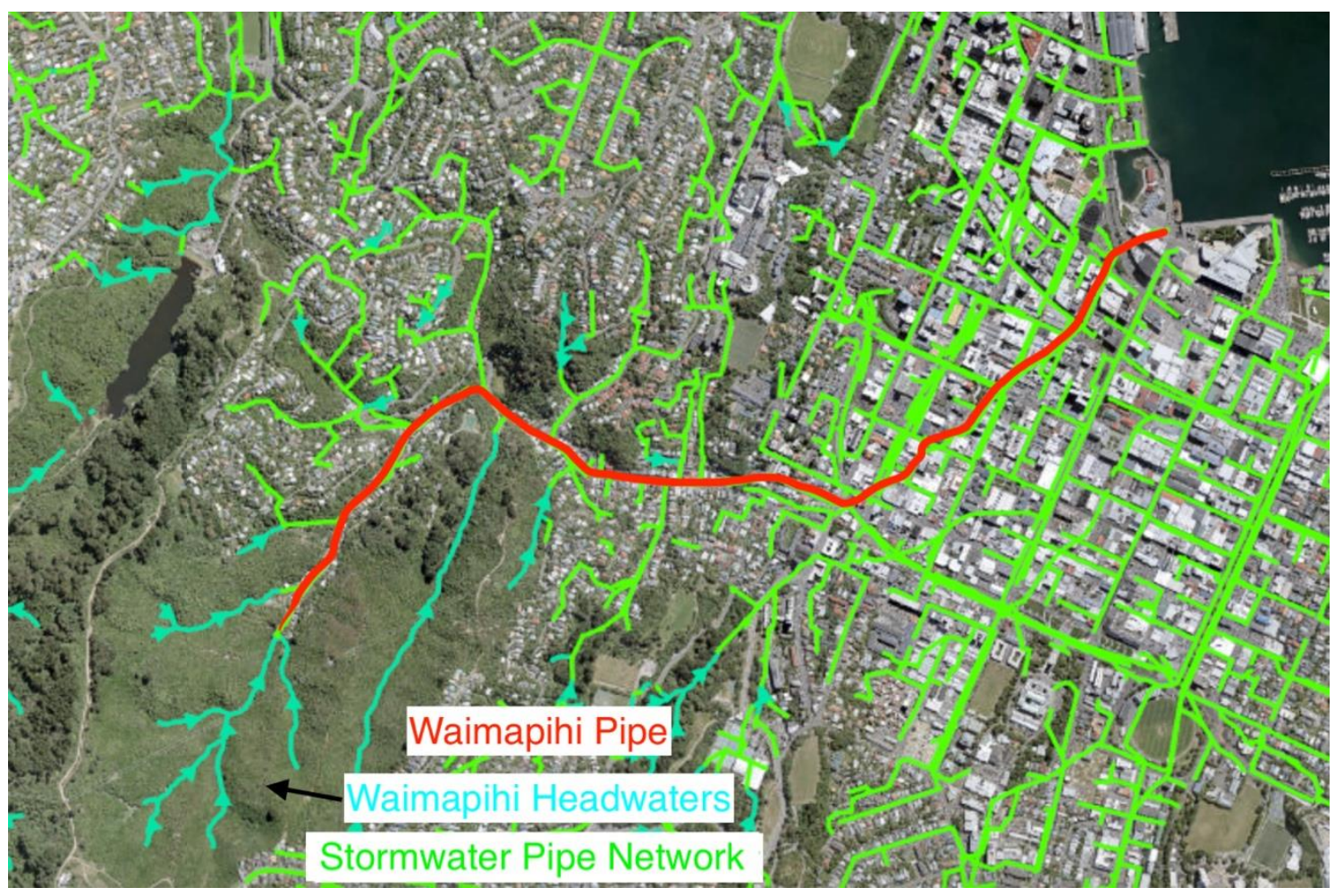

Figure 10: Path of the pipe of the Waimapihi, indicated in red, and stormwater pipes in the system, direction of flow indicated with arrows. Adapted from Water and Drainage-LocalMaps, by WCC, 2019, Retrieved from:

https://gis.wcc.govt.nz/LocalMaps/Viewer/?map=57fb534c2174471ca485132112088afc

Urbanisation has redefined the meanings around water, introducing the concept of stormwater, as different to wastewater, water supply, and waterways such as streams (Swyngedouw, 1996). Stormwater is a socio-natural assemblage, produced from the material flow of water, ecological cycles, the infrastructure of the pipe, and the institutional power that defines it to be stormwater and manages its flow (Cousins, 2017a). Stormwater is fluid in both material flow and properties; as it flows across the landscape it interacts with humans, fish, pipes, streets, buildings, pollution, government organisations, and policy, constantly changing as it flows. Thus, stormwater is a social and political construct, it is only known as stormwater because of management regimes and attempts to control what is essentially just rainwater (Cousins, 2017a). A salient example of this social construction of stormwater is the changing legal definition and protection it receives as it moves from surface water in a stream into the pipe (Cousins, 2017b). Once in the pipe, stormwater is not legally considered water under the RMA (1991), it is considered discharge. As Phill, senior policy analyst at GWRC, states: "Water in a pipe is not legally considered a stream, it's not even legally considered water" 
(Interview with Phill, 2 August 2019). Piping the waters of the Waimapihi means it is defined as stormwater and influences how it is treated and managed (Cousins, 2017b). This presents a contradiction to the protected status of Waimapihi's headwaters in the Waimapihi Reserve, demonstrating the disjointed legal and colloquial definitions of water within the Waimapihi Stream, and between different "types" of waters.

Regulation for stormwater (including the piped Waimapihi Stream) is effects-based (where the effects of activities, rather than the activities themselves, are managed) under the RMA (1991). Central government, through the Ministry for the Environment (MfE), provides national direction around freshwater by setting specific requirements in the National Policy Statement for Freshwater Management (NPS-FM) (2014) and National Environmental Standards (NES). These requirements inform regional council's regional freshwater plans. Compliance, monitoring, and enforcement of these requirements and standards is also the role of regional councils, or council owned organisations such as WW, resulting in vertical integration of stormwater and freshwater management, i.e. regional councils grant and monitor consents for different users of freshwater (Department of Internal Affairs, 2017). WW are users of freshwater, they discharge stormwater into freshwater and marine environments, which is a consented activity under the RMA (1991) (Greater Wellington Regional Council, 1999). In discussing the role of GWRC as the regulator for resource consents for stormwater discharge, Phill describes the thirty-year global consent (for all pipes in the region) for stormwater discharges across the region, that is meant to simplify the process, rather than having a separate consent for each new pipe.

We [GWRC] are a regulator so our other department, environmental regulation, will manage consents for stormwater discharges. So we are aware that Wellington Water is going through a what's called thirty year global consent for stormwater discharges, so rather than saying we are building a new pipe we need a consent for that pipe, but saying actually we want a consent for our whole service area which is all of Porirua, all of Wellington, all of Hutt Valley and I think they do some, have a role in Kāpiti as well. So it's huge, but thinking discharge standards should be set fairly uniform, you know it's a massive undertaking, it's been years in the 
making, consulting with iwi and all major things just to get this consent for their services, but we are the regulator of that and it's almost all complete, so it's all confirmed, it's literally been four of five years in the making (Interview with Phill, 2 August 2019).

The long and complicated process of granting a global consent for stormwater discharge in the region, places a uniform standard for all discharges of stormwater into freshwater and marine receiving environments. However, this uniform standard means pipes that contain a stream, such as the Waimapihi, are treated the same as pipes that contain only stormwater; this demonstrates the significant gap in the law around piped, buried streams (Elmore and Kaushal, 2008). The lack of understanding and acknowledgement of buried streams in the RMA (1991) contributes to this gap in freshwater legislation. Significantly, the lack of separation in the understandings between buried streams and stormwater contributes to this lack of regard for buried streams in legislation.

Considering buried streams are synonymous with stormwater makes people's perceptions that stormwater is polluted more worrying. The common idea participants articulated when they were asked their opinions of the term "stormwater" was of stormwater being dirty. Rachel, a relative of the artist of Te Aro Park, was emphatic saying: "It's filthy! It's unfiltered, it's untreated, every little bit of rubbish just washes in there" (Interview with Rachel, 29 August 2019). Bob reiterated this, saying "I just think contaminants, all that sort of stuff running off from car brakes, tyres, rooves, sediment" (Interview with Bob, 18 July 2019). Legally in Te Whanganui-a-Tara-Wellington, nothing but rainwater should be entering stormwater, but this is not the case; rubbish, heavy metals, hydrocarbons, chemicals, and effluent leaked from wastewater enters stormwater (Greater Wellington Regional Council, 1999). These ideas of dirty stormwater continued to feature in discussions about the Waimapihi and stormwater. When I mentioned to participants that the Waimapihi flowed in the same pipe and was mixed with this "dirty stormwater" responses included sadness and anger. Sandra, owner of Pizza Pomodoro, said "the fact that it has been combined along with [stormwater], so now it has lost its identity as a stream, yeah I think that is sad" (Interview with Sandra, 23 August 2019). Rachel agreed saying "that makes me feel really unhappy actually! It's the mauri of moving water, it's the essence of life, and not to protect it in some form is, in my opinion needs addressing" 
(Interview with Rachel, 29 August 2019). These concerns about lost identity and impact on mauri from mixing streams with stormwater are echoed in work by Durie, et al. (2017). Lily, former resident of Holloway Road, expanded on this sentiment when she discussed how she feels that it is wrong to mix the Waimapihi with stormwater, and to bury the stream at all:

You know there is that tikanga around you can't put anything, like no discharge or stuff goes in the water, that's just fundamental. And so then that's where again, on the basic level, putting the water under the ground becomes confusing because you've got Papatūānuku, who is forgiving, things can go there and sort itself out and things. So we've made that place for that reason. And then to put water there is to go against the very understanding that water does not mix with that stuff, what stays up here and up here is not where you leave waste and discharge (Interview with Lily, 24 July 2019).

Lily discussed the tikanga of not mixing different waters, that it is wrong to mix discharge and waste into the Waimapihi. She mentions how water and waste have been separated in the past by having water on the surface and burying waste, allowing Papatūānuku to deal with it. Durie, et al. (2017) echoed this when discussing how water may become hāparu when the natural flow is modified or when different waters are mixed. Further, they discussed that discharge of waste into a waterway is highly offensive to Māori (Durie, et al., 2017). While, Tipa (2009) argues that it is important to understand the cultural context around waterways, as mana whenua have an in-depth knowledge of an area and its inner workings. Therefore, it is important to acknowledge the diverse ways people have interacted with the Waimapihi, to explore how they have shaped it and it has shaped them. This demonstrates another social construction of the Waimapihi and stormwater, with principles about practice and care, as opposed to not even being considered water in the pipe.

The built infrastructure of the pipe has significant impacts on the direction of flow and state of the waters of the Waimapihi, and informs how it is understood. Gillon and Gibbs (2019) discuss how a more-than-human approach could be used to explore the built environment, and how structural, maintenance, repair, and spatial geographies could be 
examined. Their approach examined the instability of the built form, how it is constantly being made or unmade; which provided an example of how this approach could be used to explore the piped section of the Waimapihi, specifically the impacts of age and maintenance of the pipe and the development of the city (Gillon and Gibbs, 2019). Around the world, there has been neglect of urban infrastructure, including stormwater infrastructure, resulting in ageing, degraded, and leaky stormwater infrastructure that will require a high, long-term cost to repair (Swyngedouw, et al., 2002). Phill discussed how this has played out in Te Whanganui-a-Tara-Wellington, with the lack of maintenance and oversight leading to issues with cross-connection between wastewater and stormwater, causing major pollution in the Waimapihi Stream.

I think the colloquial term is that, this is not an exact figure, but something like 70 to 80 percent of the stormwater network has reached its end of life ... that's because of decades of underinvestment, people want to keep rates down, what do they not spend it on. Well the operating budget is to maintain things, because it is a, for them it is like a capital investment, we've built the pipes now and, of course, you have to maintain them, and replace them. And they maintain them when they come aware of a leaky pipe that is putting water onto the road, but you know we want to reduce that maintenance budget and keep rates down, but then you get way behind on the scale of maintenance. So we are in a legacy issue of stormwater, wastewater. Wastewater is also an interesting one, that has its own issues because, whether it is because of lazy plumbers or whether its whatever, you can get wastewater pipes from houses going straight into stormwater, completely untreated, that's toilets, laundries, showers, sinks, all of that stuff just going straight in. So that's the cross-connections issue, and that's actually a very big issue that's responsible for a huge amount of pollution. So some of the pollution like heavy metals are from the surfaces that get into the stormwater, but a whole bunch of other issues are to do with things that shouldn't be in that system. There is a poor separation between the wastewater and the stormwater, especially also where wastewater pipes get leaky or broken, and then they are leaching, and then if you also have stormwater pipes that are leaky then they will pick up that, what was contaminated, so it's interlinked (Interview with Phill, 2 August 2019). 
The stormwater infrastructure of Te Whanganui-a-Tara-Wellington is ageing, as it was built in the development of the city, around 150 years ago, and it is largely hidden, so maintenance has been inadequate, as it is challenging and out of sight (Department of Internal Affairs, 2017). Water infrastructure is particularly challenging because there are tensions between the flow of water and fixity of the infrastructure controlling it (Cousins, 2017b). Material decay and disrepair of the pipes from the water flow within them occurs on a long-time scale (Gandy, 2004). However, short term immediate damage from sudden events, such as the Kaikoura earthquake of 2016 that shattered many of the pipes, can also occur. These degrading and damaged pipes can be leaky, and water loss (in some cases) can cause floods, which changes the perception of water from a resource into a disruption, and even a danger (Kaïka and Swyngedouw, 2000). An example of this was the bursting of the wastewater pipe in central Te Whanganui-a-Tara-Wellington, over the 2019 Christmas period, with sewage leaking into the Harbour prohibiting swimming (figure 11) due to health risks from bacterial contamination. The cross-connections between stormwater and wastewater is a significant issue for the quality of stormwater (which includes the Waimapihi Stream) and the Harbour, as the receiving environment (Chakravarthy, et al., 2019). The proximity of stormwater, wastewater, and open waterway networks (figure 12) demonstrates the ease with which leaky crosscontamination can occur. Therefore, infrastructure is an active agent in the state of the Waimapihi, it ecologically and socially transforms the waterway by capturing water and contaminants, engineering the flow direction and rate of water and fish, and changes the legal definition of the water (Swyngedouw, 1996; Gandy, 2004; Cousins, 2017b). 


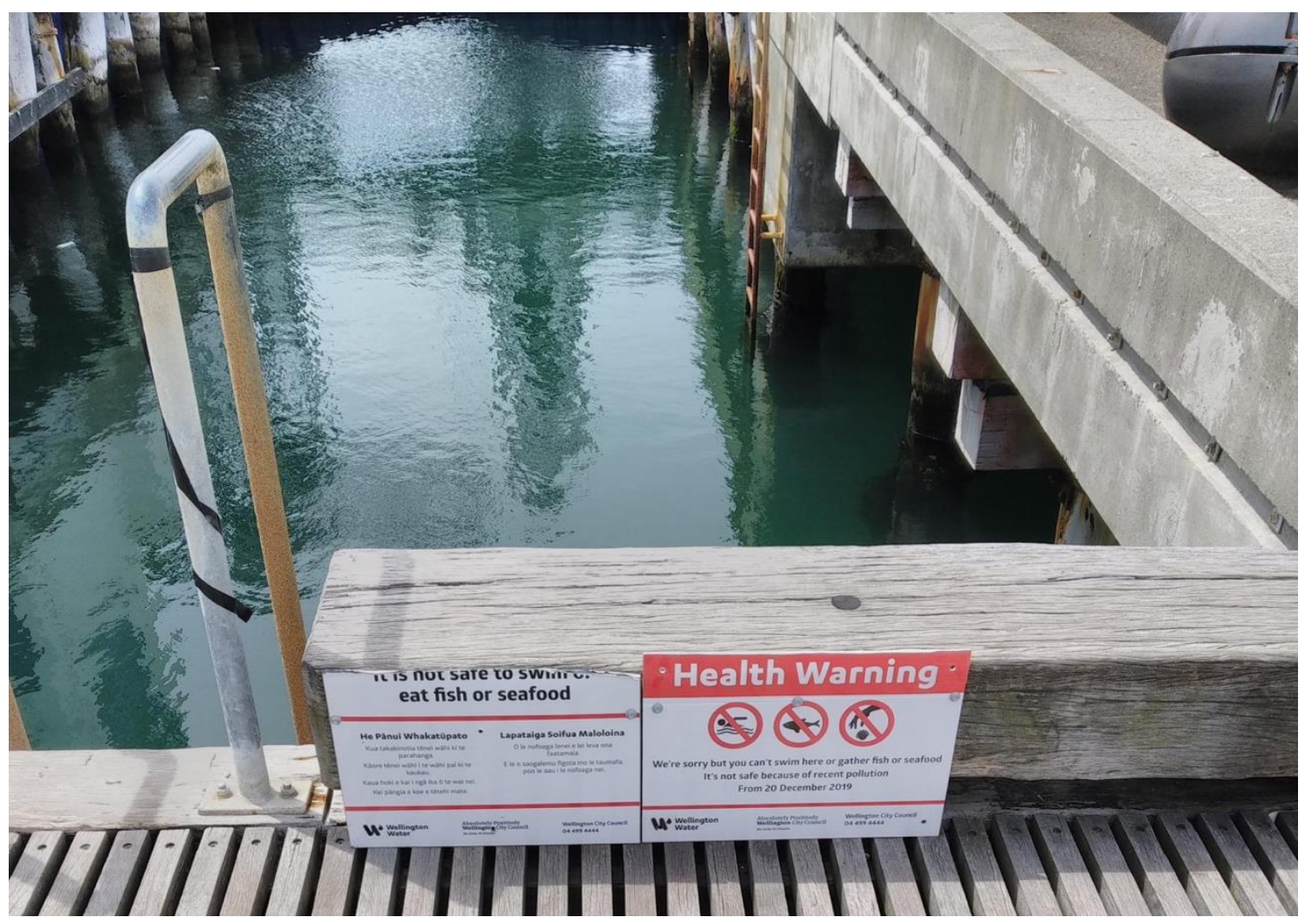

Figure 11: Image of sign at Waimapihi outlet warning against swimming due to bacterial contamination.

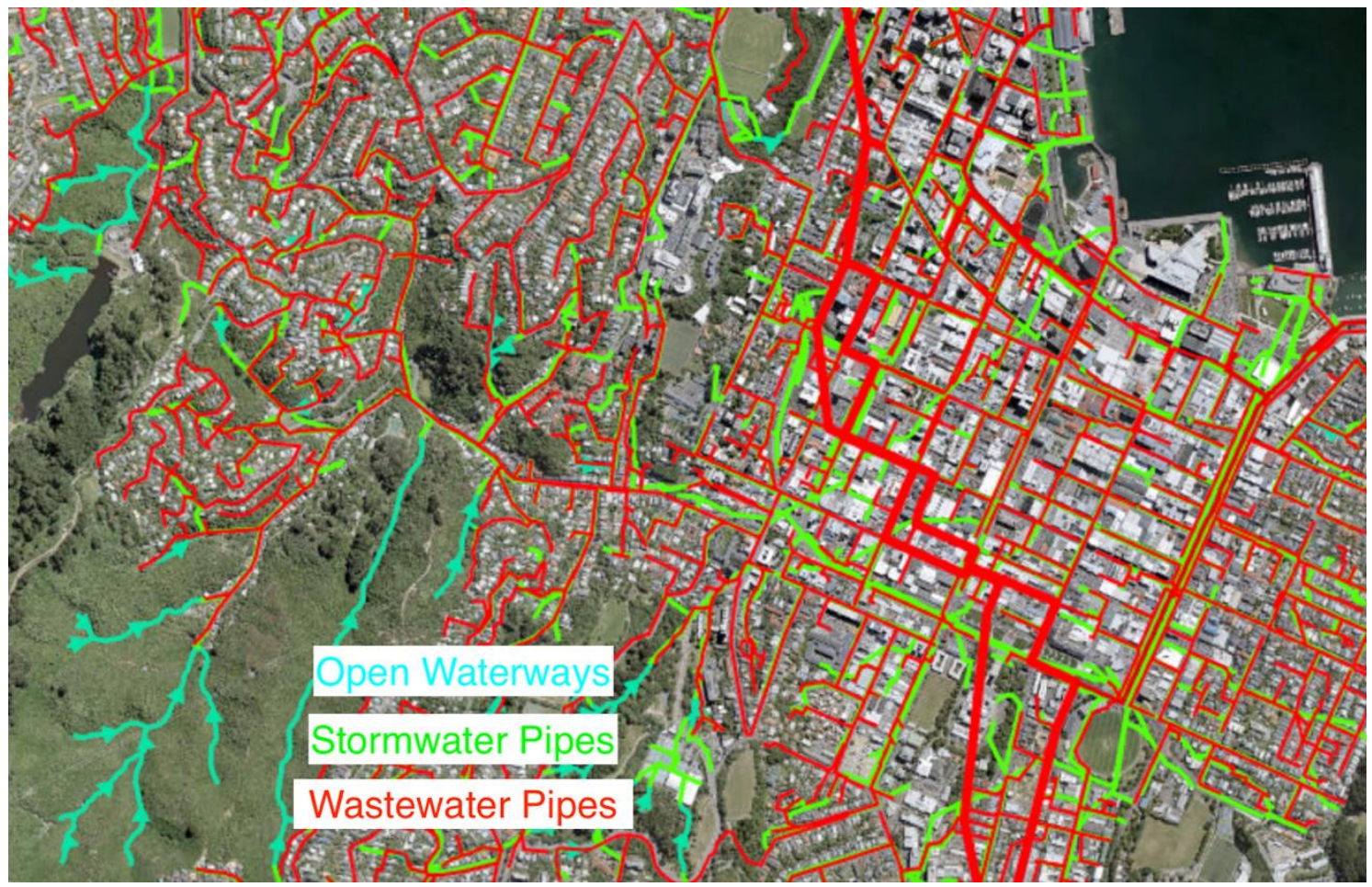

Figure 12: Map of open waterways, stormwater pipes and wastewater pipes in Te Aro and Aro Valley in Te Whanganui-a-Tara-Wellington. Adapted from Water and Drainage-LocalMaps, by WCC, 2019, Retrieved from: https://gis.wcc.govt.nz/LocalMaps/Viewer/?map=57fb534c2174471ca485132112088afc 


\subsection{Daylighting the Waimapihi Stream}

Gibbs (2018) discussed the need for hope in the face of the "gross abuse of rivers" (and streams) and suggests the first step should be to "creatively imagine the sorts of water places with which we want to live into the future; then think and enact the kinds of institutions and practices that will enable such places and relationships to flourish" (p. 59). This frame of thinking was a part of my approach in the interviews; I wanted participants to explore how they would like to see the Waimapihi Stream into the future, in their ideal world. This line of questioning initiated some creative responses and some questioning of the status quo approach to urban freshwater management in Aotearoa-New Zealand (Gibbs, 2018). Discussions about the future of the Waimapihi led most participants to mention daylighting. Daylighting (or deculverting) involves bringing a stream to the surface, out of the pipe, and restoring it to less modified stream conditions (Wild, et al., 2011). This section will discuss the potential future phase of the Waimapihi, as a daylighted stream. Below, I examine themes around daylighting as a way of reconnecting with the stream and improving biodiversity, as well as barriers to daylighting.

There was wide agreement that, wherever possible, attempts should be made to daylight sections, because as Wild et al., (2011) discussed, this can help to reconnect people with their local environment and reinstate the importance of water in the urban environment. Sandra said, "it would be great to open up parts of it [Waimapihi] in Wellington, that would be so great, within the park maybe, wherever it was feasible within the park" (Interview with Sandra, 23 August 2019). While Ra suggested "maybe right behind Z petrol station could be quite good, you could build a little water park there" (Interview with Ra, 23 July 2019). Everyone agreed that trying to daylight sections in parks or unused pieces of land would be good options to daylight the Waimapihi. This demonstrates that these highly urbanised streams will never be fully restored to their former state because the impacts of urbanisation cannot be undone, but adjustments can be made to some of the most degrading aspects of urban streams (Moran, 2007). Another option Bob raised was "if it's just flowing under a big fat median strip, why not?" 
(Interview with Bob, 18 July 2019). The participants were creative in their suggestions of places to daylight sections of the Waimapihi. This hope approach encouraged people to think of how they would like to see the Waimapihi into the future, without getting stuck thinking about the limitations, to foster creative thinking.

A key point the participants discussed was how bringing the stream into view could also help people see the impacts of any restoration or protection actions. Access to an open stream is much simpler, cheaper, and safer than trying to enter a pipe, therefore, any monitoring, maintenance, or restoration projects are much more effective in open streams than in underground, out of sight pipes (Wild, et al., 2011). Bob revealed that lack of access to the piped section stopped research on the piped section of the Waimapihi, saying "we haven't done any piped stream work there because it's quite hard to access the piped sections there" (Interview with Bob, 18 July 2019). While, Ben, chief advisor in stormwater at WW, described how bringing the Waimapihi to the surface would mean people would see when the Waimapihi changes.

If people can see it and interact with it, it becomes much more real and it also, people become a lot more reluctant to put paint down the stormwater, or to pour oils or ... throw their litter into it, if it's collecting there and they can see the impact of it. At the moment, it is outlet under the wharfs so anything that goes down there, no one would ever know if it was, what it was like. So there is quite a bit of benefit in giving people a visual impact to the actions that they take in and around the catchment (Interview with Ben, 19 September 2019).

This ability to interact with the Waimapihi daily would enable people to develop a knowledge of it, and then they would be able to monitor changes in it over time (Moran, 2007). This idea of building an understanding of the Waimapihi through daily interaction with it is similar to the indicators developed by Ngāi Tahu in conjunction with Tipa (2009), which she described as a mix of physical and value-based attributes that Māori ascribe to freshwater. She describes these indicators as having evolved from the experience of being in and near a waterway, to having an understanding of a waterway, but not just the water, also the channel, riparian margins, and abundance and diversity of 
life supported in and adjacent to the waterbody. Providing the opportunity for people to experience the stream sensorially, to see, hear, smell, and feel flowing water and the life within, may enable a greater understanding and appreciation of the Waimapihi (Wild, et al., 2011). Examining changes in the ways people interact with the Waimapihi between its open and piped sections may suggest the ways people would interact with the Waimapihi in the future if it was daylighted. As Gibbs (2009) argues, having an understanding of the history of a place and the intersecting socio-natural processes occurring in and around the stream is easier when you can see and connect to the stream.

The improvements in biodiversity of the Waimapihi that would result from daylighting was another point raised by the majority of participants. Phill described how daylighting could be an approach to reintroducing key spawning areas for Indigenous fish species (see also Paul and Meyer, 2001).

Trying to identify where in that catchment could we reintroduce that habitat, which might mean resurfacing a part of the stream or shifting a road so we can get bits of wetland habitat, so something can spawn or an egg laying area (Interview with Phill, 2 August 2019).

Providing a diverse range of habitats to support multiple species is important to improve the ecology of the stream, and can include introducing boulders, woody debris, and riparian planting (Neale and Moffett, 2016). During spotlighting in the headwaters, we saw two species of freshwater fish and one decapod, seeing this few species is indicative of what McEwan and Joy (2009) found, that species richness is lower in urbanised streams than forested streams in Aotearoa-New Zealand. However, stream biodiversity is not just about fish, it is the complex interactions between multiple species in stream ecosystems (Paul and Meyer, 2001). Frances highlighted this when she discussed the importance of insects as part of aquatic and terrestrial food webs, and that streams are habitat for a variety of species.

All those insects that come out of the stream as adults, they go into the trees all around, the birds can eat them, they travel up to $60 \mathrm{~m}$ from the stream. All those aquatic insects, they don't spend their entire life in the stream, so they are feeding our birds, especially in spring, when they've 
got babies to feed they need lots of protein. So we need all those bugs in the stream (Interview with Frances, 25 July 2019).

Daylighting will reconnect the stream to the processes in the surrounding environment, such as photosynthesis (producing energy from the sun) and aerial colonisation of insects which enables vital ecological processes to occur in the stream (Neale and Moffett, 2016). Colonisation of insects into the stream requires a source for these insects, a vegetated area nearby, which highlights how the surrounding environment needs to be considered in any restoration projects for buried streams (Wild, et al., 2011).

Despite the enthusiasm to daylight parts of the stream and the perceived benefits, there was agreement that significant challenges would arise when trying to daylight the stream. There was general agreement among the participants, and described by Phill, that daylighting would have to be in sections, and not the whole stream, because it is located under the central city, under infrastructure that is used daily by the city's residents.

It's very hard to undo what we've got in Wellington City, if we tried to resurface all of those streams we would have to vastly change the urban form, move whole buildings, so some of it is a bit of a too hard basket, but you can have spaces for opportunity (Interview with Phill, 2 August 2019).

The development of cities on top of streams has been seen as a major limitation for the daylighting of highly urbanised streams (Moran, 2007). Paul and Meyer (2001) have discussed the challenges of urban stream restoration. They note that there is a challenge of integrating physical, chemical, and biological processes to rehabilitate impaired ecosystems, in addition to the requirement of paying attention to aesthetics and human attitudes towards the landscape. A key limitation, related to being underneath the city, is the expense of daylighting, the project to daylight streams in 2013 in La Rosa Reserve in Tāmaki-makau-rau-Auckland cost \$4000-\$5000 per linear metre of stream (Thompson, 2014). Bob highlighted the expense when he said, "it's that whole sort of what's the best option, the easiest to do, cause daylighting is an expensive thing" (Interview with Bob, 18 July 2019). This is often a challenge in environmental management, persuading politicians and the public of the value of restoration weighed against the often high initial cost. However, the ongoing cost of maintaining degrading pipe infrastructure will be 
significantly higher than the one-off cost of daylighting, this will be project specific but must be considered (Wild, et al., 2011). Another limitation is the technical difficulty of raising a buried stream to the surface that has been placed low into the ground, which was highlighted by Frances.

Daylighting streams is really fraught as well because the stream's been put down really, really low, how do you raise it up, and how do you keep hyporheic zone and keep the flow, and how do you give it room to move? It's all very tricky (Interview with Frances, 25 July 2019).

The hyporheic zone is the groundwater that is connected to the stream, it is important that it is not disconnected from the stream when it is being daylighted or else the flow of the stream will cease (Walsh, et al., 2005). Frances also describes how a stream needs to have room to expand in high flow periods, and that streams are not straight lines but meander in an undulating path, so daylighting projects need to allow for this fluctuation of streams, so can take up a lot of space.

The culmination of these challenges around the prospect of daylighting was around how the Waimapihi would fit into the city form. Some participants were concerned that if a rash decision to daylight the stream, with no consideration of what that would entail for residents and the city, was undertaken then it could end up only leading to more pollution and degradation of the Waimapihi. A lack of inclusion of residents in the planning process of restoration projects can lead to them failing, as the community is unaware of what is being done and how to interact with the area after the restoration project is complete (Moran, 2007). Lily suggested that current practices of changing the environment around us, to suit our needs, rather than changing ourselves around it, means that the city would not make room for the Waimapihi if it were daylighted. She suggested that there would need to be a shift in how we perceive the place of waterways in Te Whanganui-a-TaraWellington for daylighting to actually improve the health of the Waimapihi, rather than degrade it further.

I guess for just being aware of what you ask for and what you give back ... in the argument of 'let's daylight everything', but if we kept living how 
we live we wouldn't sustain that anyway, it would be a mess, we would pollute it all, no one would look after it (Interview with Lily, 24 July 2019).

She highlights how we cannot just force the Waimapihi into the city the way it is, that the city, and the way we live within it, would have to change if the Waimapihi was to be healthy above ground. This was echoed by Moran (2007) who highlighted that for urban stream restoration projects to be successful, consideration of the human dimensions of stream restoration must occur, alongside the physical understandings of the stream.

Having consideration of these human dimensions of the stream primarily means understanding the community the Waimapihi flows through, and the political and social processes occurring along the stream (Moran, 2007). The community around the headwaters, in Aro Valley, were considered by most participants to be environmentally aware and proactive, particularly on issues around pest control, and aware of the presence of the Waimapihi Stream. Therefore, participants suggested that somewhere in the Aro Valley, such as Aro Park (figure 13), would be a good site to daylight some of the stream because the community would likely get involved and maintain restoration work into the future. Lily suggested that the Aro Valley community were likely to care for the Waimapihi.

The kind of community that lives in that area, in Aro, I do think it's the kind of community that if it was daylighted people would look after it ... And so I think that's where you've kind of got people to a point where they're ready to be kaitiaki and they're ready to actually take responsibility and let it impact their lives (Interview with Lily, 24 July 2019).

She suggests that the community are ready to let the Waimapihi "impact their lives", believing that they will change how they live around the Waimapihi, such as make time in their days to plant and maintain riparian margins, and monitor water quality and fish life in the Waimapihi regularly. To understand how the community will let it impact their lives requires some understanding of the community characteristics, whether there are people and groups willing to put in the required work (Gooch and Rigano, 2010). There has been a global rise in local stream groups (Paul and Meyer, 2001). In Te Whanganuia-Tara-Wellington, there are groups such as the Polhill Protectors, Waimapihi Trust, 
Polhill Restoration Project, and the Aro Valley Restoration Project, who work alongside WCC, doing pest control, plantings of natives, clearing rubbish, and building and maintaining walking and cycling tracks in the Aro Valley area, including the Waimapihi Reserve (Brassell, 2014). These groups are interacting frequently with the Waimapihi, so have an understanding of its behaviours and a respect and interest in the area. Lily cautions that it cannot be forced on the community, that they need to have an active role in any daylighting activity of the Waimapihi.

It's not just an outcome thing, it's a process thing. So it's whether you just start dialogues around it, like 'what does the community think of this, where would you want to daylight it, why?'. That would be the first step I think, but yeah, I could definitely see a future where, I mean they already have little community days, and that kind of thing, that people love to go to, so you could see planting days or helping actually daylight it (Interview with Lily, 24 July 2019).

The involvement of the community from the beginning planning stages, asking them what they want, all the way to implementation, and then monitoring, is crucial for the success of a restoration project (Moran, 2007). Lily sees this as a "process" not an "outcome", and that the project cannot be a one-off event, as you need to develop dialogue with the community and plans for the future alongside the community. Kaushal and Belt (2012) suggest that any restoration project would have to take a long-term approach because there would be long-term impacts of urbanisation on buried streams into the future. Community engagement is, therefore, important, to maintain ongoing care for the Waimapihi after the initial project is complete. Furthermore, there needs to be community engagement in projects to engender a sense of care and urgency to act over the Waimapihi (Gooch and Rigano, 2010). Considering how the pipe and the Waimapihi have changed over time, and will into the future, and how people understand it, is crucial for any future plans to daylight it. 


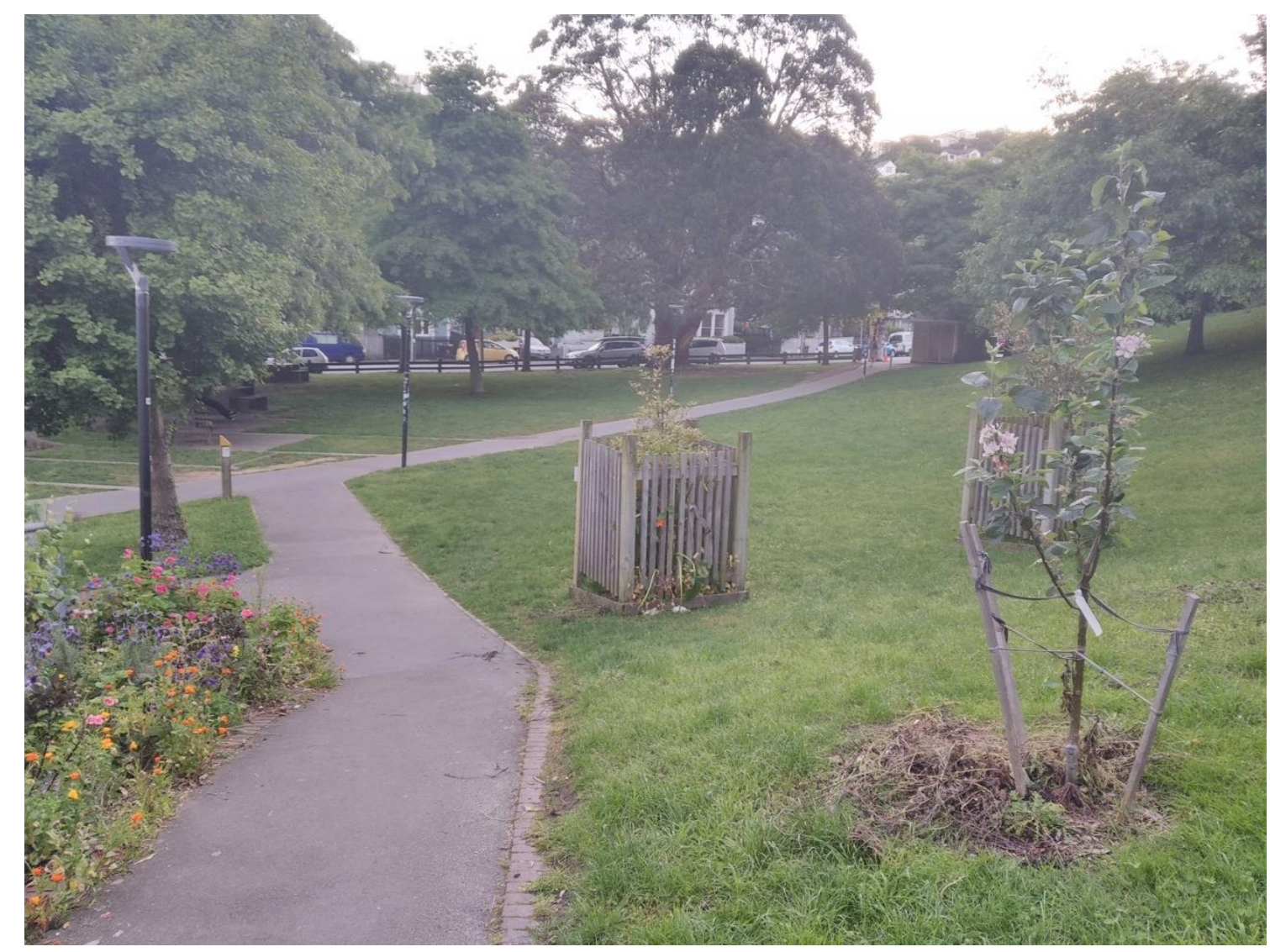

Figure 13: Image of Aro Park, where the Waimapihi Stream could be daylighted.

\subsection{The RMA (1991) along the Phases of the Waimapihi}

For daylighting or any other future improvements to be made to the Waimapihi there needs to be an understanding of how the RMA (1991), the primary legislation around environmental management in Aotearoa-New Zealand, interacts with the various phases along the stream. The Waimapihi is a continuous flow of water, but it is governed under different policies and managed by different local government agencies along its length (figure 14). Government organisations, including MfE, GWRC, WCC, and WW, have various roles and responsibilities along the Waimapihi, with aligning and conflicting agendas. This highlights the complexity of urban streams where a range of social and power relations occur along its length (Gibbs, 2018). The Waimapihi has been influenced 
differently along its length by the RMA (1991) and policy around freshwater, stormwater, and biodiversity management. This section examines the future implications of policy and management along the length of the Waimapihi, including the legal construction of different waters, and the different responsibilities various agencies have around the stream.

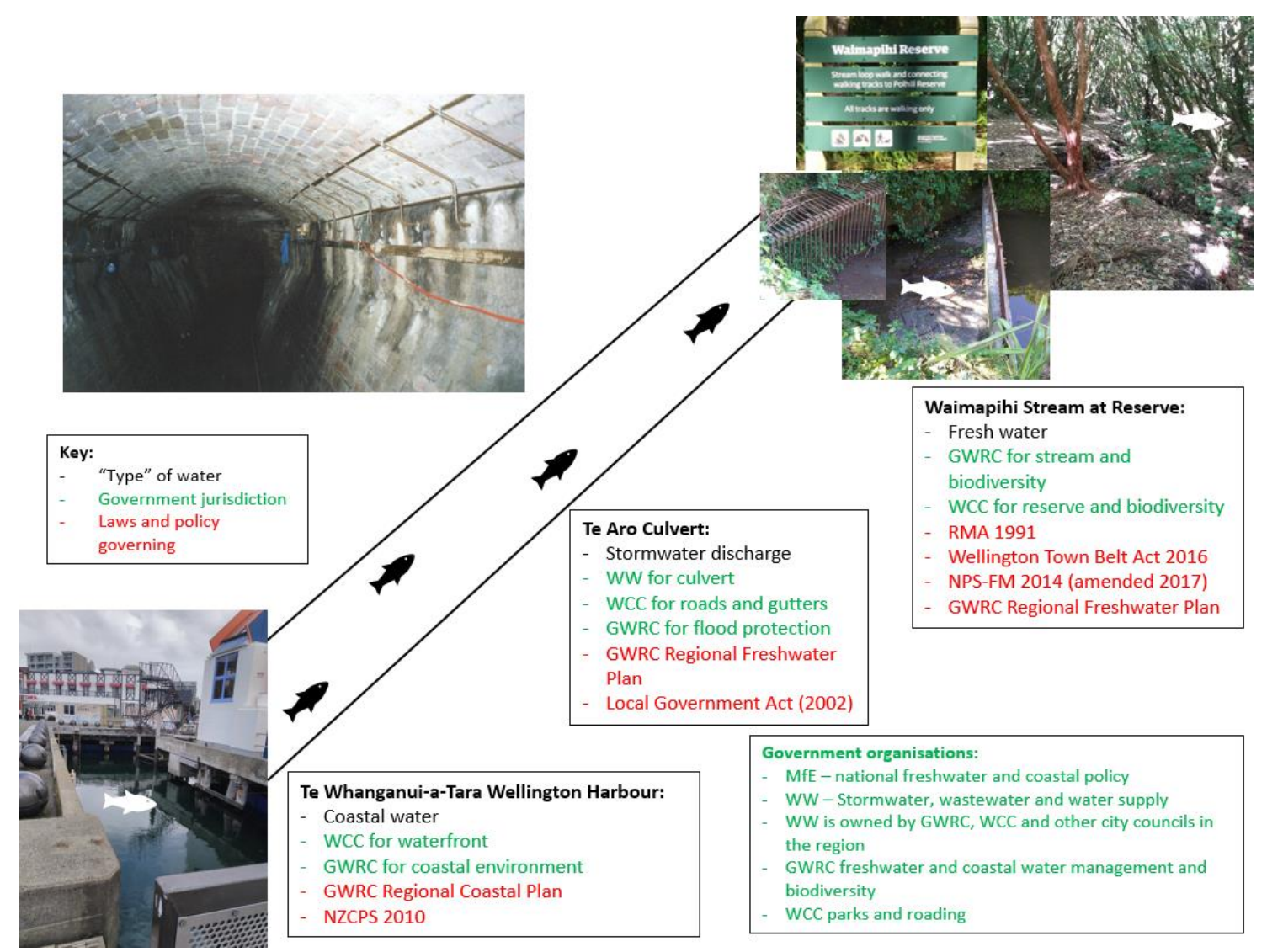

Figure 14: Diagram showing the 'type' of water, government jurisdiction, and laws and policies governing an area of the Waimapihi.

During interviews some participants discussed the prospect of changing the RMA (1991) to include piped streams in the definitions of rivers and water, as a starting point for addressing improving the health of the Waimapihi. Phill mentioned that he thought that changing the law to consider piped streams as actual streams and the water that flows in them as living ecosystems would change the way people treat the Waimapihi: 
If water itself, wherever it is, freshwater was recognised as a living being, whether it was in a pipe or not, we would then have to respect it's living, it's mauri and that I think would change behaviours quite a lot (Interview with Phill, 2 August 2019).

This perspective suggests that having legal recognition of the life of water could engender more respect and value for waterways, piped or otherwise. This recognition of water as living bears similarities to how Tipa (2009) described the Te Ao Māori view of water having mauri, and therefore supporting life within and around it, which informs the awe and respect held for a waterway. Conversely, the technical and financial barriers to changing the RMA (1991), and other legislation, to redefine a stream to include piped streams were also raised. Myfanwy, ecology team head at WCC, drew attention to the financial burden that would result from this legislation change, due to the requirement to grant and monitor far more resource consents for stormwater discharge into freshwater environments for every piped stream in Aotearoa-New Zealand.

This tension and argument between can we call it a stream, and what that means if you want to change your pipe. You've actually got to get a resource consent and think about the fish that might be living in it. But then there is the economic consequence of that, do ratepayers actually want rates to increase by like $10 \%$ to cover the cost of all of that sort of work (Interview with Myfanwy, 2 September 2019).

Myfanwy highlights the changes that would need to occur in how the pipes are understood and managed if they were legally considered streams, and that resource consents to discharge into them would be required to consider the fish in the pipe. This change in practice would require monitoring of water quality and fish life in the pipe, it would set a much higher bar for protection than is currently in place. She highlighted the financial cost, inevitably passed on to ratepayers, for the work of reviewing and granting all the consents that would be required for all of the pipes connected to buried streams. This can be some of the thinking that can predominate when freshwater management is technocratic, that financial cost is privileged because it is quantifiable so easy to measure. However, financial cost should not be the only consideration, the social and ecological value of urban streams should inform decision making processes. Furthermore, improving biodiversity and the health of waterways is mandated under the RMA (1991) and NPS- 
FM (2014), but unless there is an acknowledgement that buried streams are both water and fish habitat, this will not be achieved. This demonstrates that social power and institutions that define entities which inform policy have significant influence on how those entities are understood, treated, and valued (Bakker, 2003).

When discussing the Waimapihi's future there was general agreement amongst participants around the incongruence of freshwater, stormwater, coastal, and biodiversity policy around urban streams in Te Whanganui-a-Tara-Wellington. They felt that the Waimapihi cannot be managed as a whole if it is separated into open and piped sections, that are managed separately due to them being legally understood to be different "types" of water (Cousins, 2017a). Participants believed that if improvements are to be made in coastal and freshwater quality, and biodiversity, which the RMA (1991), NPS-FM (2014) and New Zealand Coastal Policy Statement (NZCPS) (2010) all stipulate, then changes in policy to better align them will need to occur. Having an understanding of how these various policy groups conflict and align is vital for improving the health of the Waimapihi into the future. Furthermore, having an understanding of the social and political context within which the practices and processes for governing water in Aotearoa-New Zealand arose is important for understanding the processes of buried stream governance (Bakker, 2012). Phill described the process of buried urban stream governance when he said:

I'm in the environmental policy department and my core role is to help run a collaborative decision-making process around freshwater management, and setting water quality limits and targets, including coastal human health swimming water quality standards. Working back up stream, that is going to profoundly affect the future development of the city, and the quality and methods of stormwater and wastewater management (Interview with Phill, 2 August 2019).

He highlights the interaction between coastal and freshwater policy, and how this in turn will influence stormwater and wastewater policy and management, which will in turn influence the urban development of Te Whanganui-a-Tara-Wellington. The interaction of all these complex policy groups is unique to buried urban streams, and therefore, current freshwater management regimes based on rural or "natural" streams are inadequate for 
managing them. Furthermore, policies need to be complementary for effective management of buried streams, or else there will be conflicting actions taken and no progress made. This demonstrates the agency of water flow and the pipe to inform policy and practices that govern the management of the Waimapihi (Bakker, 2012).

As a result of the Waimapihi covering such an array of policy groups, by dint of being legally understood as an array of waters, various departments in the GWRC have to interact when managing the Waimapihi. There is complexity in GWRC processes for freshwater management that require interactions between various departments, as described by Phill:

That is the whole thing about policy, in a way it sets a framework and it sets objectives, but the policy department itself doesn't do the doing, but biodiversity, land management, environmental science, those groups do, and flood protection, through the programmes they invest in, all have a role in those things. It sort of remains to be seen how joined up can those multiple programmes actually be. Things in a large organisation have a tendency to become siloed, and people not knowing what other people are doing, and it's just an inherent challenge, but it is something I think our council [GWRC] is really aware of (Interview with Phill, 2 August 2019).

This demonstrates the complexity of the regional council processes in Aotearoa-New Zealand, and some of the challenges this can lead to, including inertia and miscommunication (Department of Internal Affairs, 2017). It also highlights how complex taking action on the buried streams will be, how it will involve action at the policy level, which will then inform investment and action in various groups including biodiversity, environmental science, land management, and flood protection. The main challenge is ensuring communication between the groups, and follow through between policy frameworks, group strategies, investment plans, and programmes of action.

The roles of regional and city councils are not distinct, there is crossover between them (Department of Internal Affairs, 2017). For example, regional councils oversee 
freshwater management and public transport, which operate on urban infrastructure, in their regions. While city councils manage urban infrastructure and greenspaces, which often contain waterways. Urban streams, therefore, come under the jurisdiction of regional and city councils, presenting the challenge of effective communication and aligning goals between councils (Department of Internal Affairs, 2017). The various participants from the councils voiced these challenges, of trying to communicate and align objectives and actions between local government organisations on such a complex issue. Myfanwy discussed, in her interview, the struggles she had faced as an employee of WCC trying to "cement the fact that city council has a place in dealing with urban streams" (2 September 2019). She suggested that an integrated approach was needed between WCC and GWRC on freshwater:

Setting up the urban ecology team, you know getting more resources, making sure that [Wellington City] Council had a role in the freshwater space, because that was always a bit of a struggle, that the city council doesn't have anything to do with streams, it's a regional council issue, and it's kind of like actually we need to be more integrated than that (Interview with Myfanwy, 2 September 2019).

This integrated approach needs to not only include GWRC and WCC, but also WW as they operate the pipes the Waimapihi flows through. WW is a company that is equally owned by Hutt, Porirua, Upper Hutt, and Wellington city councils, South Wairarapa District Council and GWRC; they own the infrastructure, but WW operates it. Phill described the various power relations between different government organisations that this setup produces, "Wellington Water, which is actually co-owned by all the councils and all the infrastructure is still council property, it's just that this is the operator" (Interview with Phill, 2 August 2019). Having an understanding of the various roles of organisations, and how they interact to complete these roles, is essential (Cousins, 2017a). WW's role is to manage and maintain the pipes and provide the services of water supply, stormwater, and wastewater management. While GWRC manages freshwater and grants, monitors, and enforces resource consents; and WCC manages urban infrastructure. Phill expanded on this, when he mentioned that WW just manages the pipes and what is in them, but they do "not necessarily generate the pollution that they receive, it comes from drains" in the city (Interview with Phill, 2 August 2019). He describes how WW manages 
the infrastructure the polluted water flows through to the Harbour, but that there is little they can really do to reduce that pollution once it enters the pipes, and rather that needs to happen earlier in the system. This exemplifies the need to consider the Waimapihi as a whole system, which requires an integrated approach between GWRC, WCC, and WW (Cousins, 2017a). However, this disjointed relationship is starting to change, as Phill did mention, some collaboration between GWRC and WW is beginning take place on freshwater policy development:

But we have people from Wellington Water on our [GWRC] project team for our freshwater management, because we need their knowledge, we need their advice about how things work, and we are offering them some funding to do further studies about how their discharges are affecting the water quality and environment (Interview with Phill, 2 August 2019).

This demonstrates how invaluable knowledge sharing between these organisations is for understanding the complexities of urban freshwater management. Water management is not just technical, able to be addressed through infrastructure provision and scientific expertise, but political involving human organisations, behaviours, and values (PalominoSchalscha, et al., 2016). Consequently, there is a clear benefit in using a hydrosocial approach to understand a buried stream that considers: institutions and social power, alongside the social life of fish in the stream, the infrastructure of the pipe, the structure of the city, and the flow of water above ground and in pipes as stormwater (Linton and Budds, 2014). Taking a hydrosocial cycle approach encourages examination of aspects of the Waimapihi that can be missed with other approaches, for example, the institutions and power that governs the flow of, definitions around, and value placed on water.

\subsection{Conclusion}

The criteria of what a stream is understood to be (its characteristics and behaviour), and how a particular waterway fits into that, is socially devised and informs how it is manged and treated (Blue and Brierley, 2016). However, urbanisation has resulted in major 
modification of urban streams, changing them to the point that accepted understandings of streams no longer fits them. Consequently, the legislation designed to manage them is severely limited, in particular, the burial of streams has rendered them no longer governed under the RMA (1991). This, alongside urban streams being under the jurisdiction of multiple local government organisations, has had significant impacts on how urban streams are understood and managed. Therefore, the interactions between the social power and institutions and the infrastructure of the pipe informs the meanings produced around the Waimapihi (Linton and Budds, 2014). This demonstrates that freshwater management is social, and not just technical. Therefore, an approach such as the hydrosocial cycle for understanding streams is more appropriate than the predominantly technocratic approaches that currently inform most freshwater management in AotearoaNew Zealand.

The hydrosocial cycle has helped me to make sense of the Waimapihi, by encouraging me to explore the various phases of it and to investigate the complexity within it. This complexity arises because the Waimapihi Stream is not uniform spatially or temporally; it encompasses various phases that have been discussed in this chapter. Starting in the open headwaters, this phase suggests what Te Whanganui-a-Tara-Wellington was like in pre-colonial times and demonstrates how much the stream has changed since then. Moving down the length of the Waimapihi, the piped stormwater phase reflects its current state, being forced underground, out of sight and mixed with stormwater runoff. The final phase discussed was a potential future phase of the Waimapihi, as a daylighted stream. This represented a hopeful future for the Waimapihi, that is currently polluted and disconnected from the community.

Examining these phases illustrated the complexity within the Waimapihi, which is a feature of urban streams and part of what makes them difficult to understand and manage. The hydrosocial cycle provides a framework to focus attention to the intersecting components of urban streams, such as waterflow, infrastructure, and social interactions of fish, people, institutions, and policy around the stream. These components can be examined in a more holistic way when using the hydrosocial cycle, rather than separating the stream out into discrete sections, which a more technocratic approaches often do. 
Delving into the Waimapihi, examining it at various scales, has provided an example of the value of a hydrosocial cycle approach. This approach allowed me to investigate how streams are defined in everyday understandings, and in law and policy, and what assumptions influence practices and understandings around water. Having an understanding of the context that these assumptions arise in enables them to be questioned and their roots explored. A significant component of this context is the colonial history of Aotearoa-New Zealand, and the interactions between Pākehā and Māori (and their lands). Disregarding the cultural context within which the Waimapihi is placed, neglects hundreds of years mana whenua have of living with the Waimapihi and developing an indepth knowledge of it (Tipa, 2009). Therefore, part of the value of a hydrosocial approach is to incorporate this social, and cultural, component of the Waimapihi into any understandings of the meanings around it. Furthermore, the hydrosocial cycle encourages consideration for the life in the Waimapihi, including the fish, birds, and insects, and how they interact with the water flow and the infrastructure, which plays a key role in the production of the waters of the Waimapihi. 


\section{Chapter Five: Fish in the}

\section{Waimapihi Stream}

\subsection{Introduction}

Animals are often considered as merely part of nature and as passive surfaces onto which humans can project their values and meanings (Buller, 2015). However, Bear and Eden (2011) argue that animals should be understood as part of a heterogenous reimagined society, one that includes human and non-human entities. They note that much of the literature on animal geographies has focused on warm-blooded and 'charismatic' animals, with little attention being paid to inhabitants of aquatic environments, that are perceived as cold-blooded and slimy. Aquatic animals reside underwater, so are often perceived as invisible to humans because the surface of water is reflective and frequently opaque. Furthermore, much of the fish geographies literature focusses on the interaction of humans and fish during the activity of fishing (Todd, 2014; Bear and Eden, 2011). However, this thesis differs as it explores how humans interact with fish, and the role of fish in defining and regulating urban streams and pipes. Animal geographies and many Indigenous epistemologies (including Te Ao Māori) view humans and animals as engaging in relationships that transcend dualistic notions of nature-society and animalhuman (Todd, 2014; Tipa, 2009).

In research about animals (especially fish), they are often regarded as a collective group, rather than individuals with subjective identities (Buller, 2015). However, fish can be perceived in a variety of ways, including as an individual, species, or community, freshwater or oceanic, Indigenous or introduced, endangered or abundant (Todd, 2014). Furthermore, there are diverse ways that people engage with fish, including as food, for science, sport, storytelling, philosophising, and linguistic definitions of, about, for, or 
with fish (Gibbs, 2018). Acknowledging that the word fish can mean an abundance of ideas, and can convey some of the many interactions between humans and fish, demonstrates that humans have many ways to understand fish beyond a collective group. Exploring the interactions between fish, humans, and places enables the exploration of roles fish play, and their agency in, the production of spaces in cities, such as urban streams (Buller, 2015). Examining people's interactions with fish as individuals can be achieved by acknowledging the pluralities of fish and the agency with which they can interact with humans and places (Todd, 2014). In addition to exploring fish as individuals, investigating how different species behave, and the diversity and abundance of fish species in the community, is important for examining the state of biodiversity in the Waimapihi. Attending to fish will enable the behaviours of individuals and groups, within and between species, and with the ecosystem, and the impacts of this on the Waimapihi to be examined (Gibbs, 2018). Furthermore, this approach will explore how human lives, institutions, and politics are enabled, shaped, and limited by fish (Gibbs, 2018). For example, the role of fish in the political process and the development of policy, around stormwater, urban development, and freshwater management will be investigated (Todd, 2014).

The life within the stream is a key component of what makes up the Waimapihi, and considering the presence of fish along the stream, in both the piped and open sections, is vital for understanding the hydrosocial relations occurring. Taking a more-than-human approach enabled the fish to be considered as part of the social relations occurring in the hydrosocial production of the Waimapihi. This section explores the presence, role, and movement of fish in the open and piped sections of the Waimapihi Stream. "Fish" is used to describe the freshwater fish and decapod species seen in the stream during spotlighting that are the focus of this discussion. The presence of fish in the headwaters of the Waimapihi was explored, followed by a discussion around the challenges fish face in their movement in the pipe, and the potential to enhance fish passage into the future. This section provides an in-depth discussion of the vital and complex role that fish play in producing, defining, and adding value to the Waimapihi. 


\subsection{Fish in the Headwaters at Waimapihi Reserve}

The headwaters of the Waimapihi flow through the Waimapihi Reserve that has protected status under the Wellington Town Belt Act (2016) (mentioned in the previous chapter), and therefore, the habitat quality and biodiversity must be protected. The importance of the Waimapihi Reserve and headwaters for freshwater biodiversity was discussed by Bob when he described that the "habitat values, it's really, really good" and that it is the "only section of stream with no urban area upstream" in central Te Whanganui-a-TaraWellington (Interview with Bob, 18 July 2019). Consequently, the water quality is relatively high because no contaminants or extra flow from stormwater runoff is entering the headwaters. However, Bob highlighted that there are "legacy effects" from the forest clearance that occurred in the late 1800 s for timber to build the growing city and from the area being a dairy farm until the 1960s (Brassell, 2014). During fish spotlighting we saw a couple of old tyres next to the stream, figure 15, which will be slowly leaching contaminants into the stream. The main contaminants from tyres are heavy metals including cadmium, chromium, lead, and zinc. They bind to sediment in the stream which is a food source for kōura and other invertebrates, and thus lead to bioaccumulation of heavy metals in their bodies (Hatt, et al., 2004). Therefore, despite the habitat quality being better than most other headwaters of streams in the central city, there are still issues and improvements that could be made. 

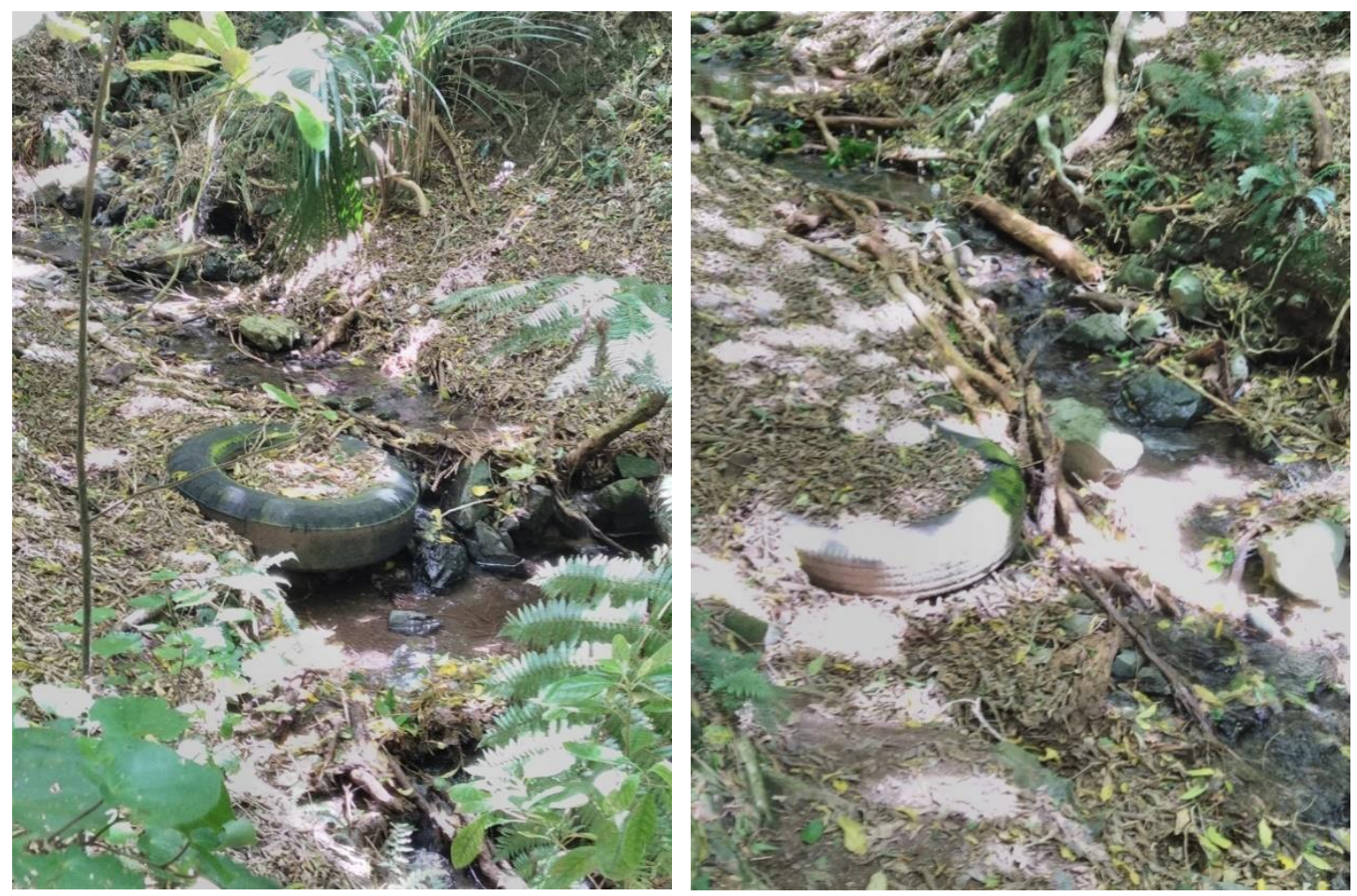

Figure 15: Images of two tyres seen in headwaters of Waimapihi.

Replanting in the Waimapihi Reserve did not occur until the 1980s, so it is a young, regenerating forest (Brassell, 2014). Such a forest lacks the complexity of vegetation that an established forest would have, such as lower canopy and shrubs along the stream edge (figure 16). Frances was a part of the restoration and reminisced:

I wanted to take what I had learnt as a gardener and apply it to restoring forest to places, native forest, and so we started work up at Waimapihi. Must have been around about 1981 that work started, I didn't start it initially. I came along a little bit later (Interview with Frances, 25 July 2019).

The lack of vegetation at ground level, and the placement of the path next to the stream, means that the land is trampled, dislodging sediment that enters the Waimapihi. This increased sedimentation can smother fish and remove space where fish hide from predators or against flood flows, meaning they can get washed downstream in floods (Paul and Meyer, 2001). Furthermore, a lack of vegetation cover reduces the input of leaf litter that is a food source for kōura and other freshwater invertebrates (Paul and Meyer, 2001). Frances also highlighted that the Waimapihi headwaters “doesn't have a huge 
amount of spawning habitat because there is a path beside it for some of the way, so it has lost it's really gentle beaches at the edge" (Interview with Frances, 25 July 2019). A lack of spawning habitat for freshwater fish is a major issue for urban streams and contributes to the reduction in fish diversity and abundance (Paul and Meyer, 2001). Consequently, despite this being considered a relatively good habitat for fish in the central city, there is still a lack of some key components that support fish life cycles like spawning areas. This highlights the need for fish behaviours to be at the forefront of urban stream management and restoration projects (Paul and Meyer, 2001).
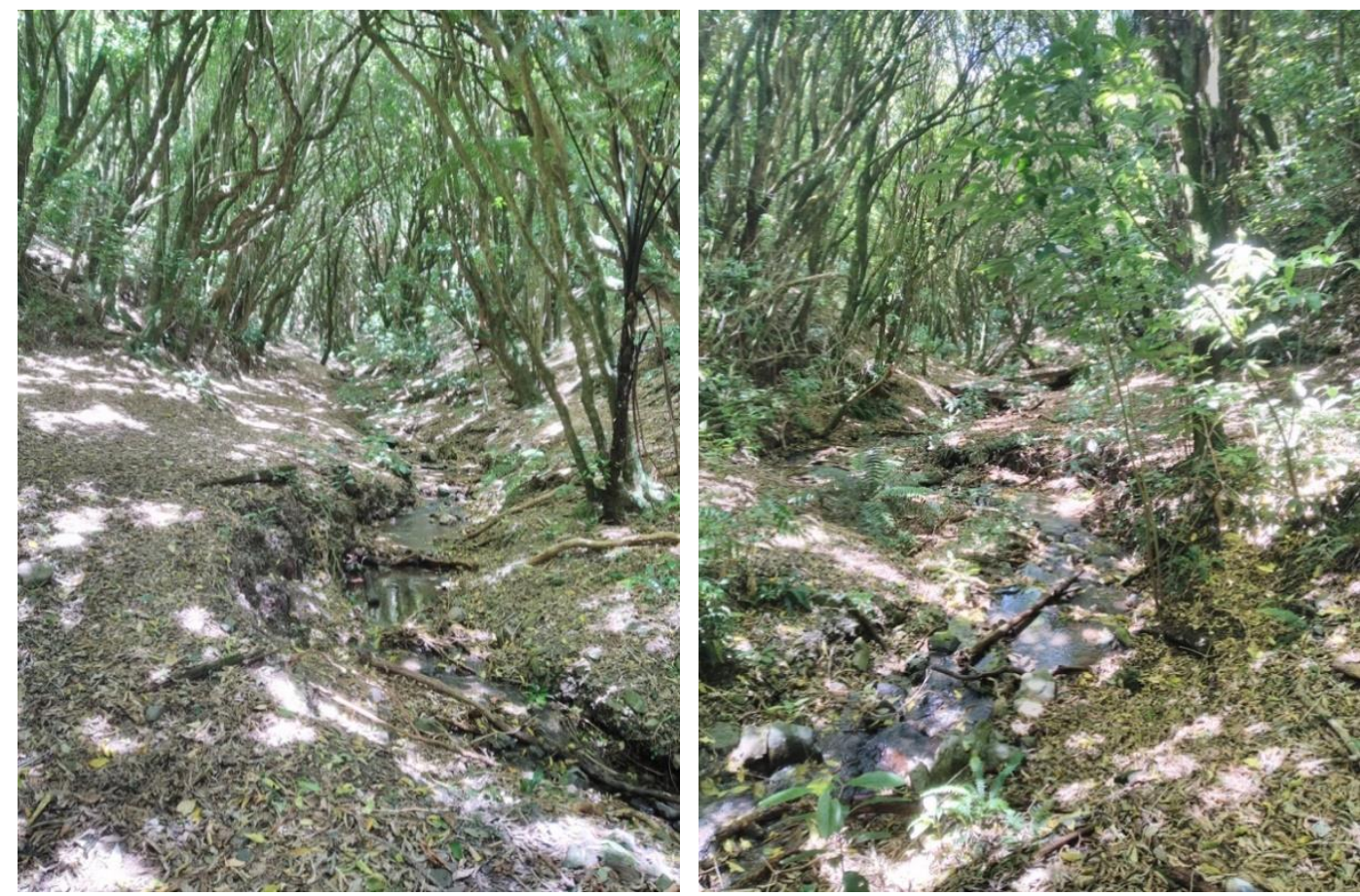

Figure 16: Image of the headwaters of the Waimapihi Stream, in Waimapihi Reserve.

Two species of Indigenous fish and one decapod were seen while spotlighting in the headwaters of the Waimapihi Stream, namely banded kōkopu (Galaxias fasciatus), kōaro (Galaxias brevipinnis), and kōura (Paranephrops planifrons). Photos taken during spotlighting show a banded kōkopu and a kōura we saw (figure 17). This was confirmed by Bob, who said when they did a survey of the fish in the Waimapihi they found "the crayfish, then the two whitebait species" (Interview with Bob, 18 July 2019). In DOC's Threatened Classifications banded kōkopu are classified as not threatened, and kōaro and 
kōura were classified as declining (Dunn, et al., 2018; Grainger, et al., 2014). The banded kōkopu and kōaro, as with many freshwater fish in Aotearoa-New Zealand, are diadromous, i.e. migratory with two movements between ocean and freshwater life cycles (Joy and Death, 2013). Consequently, they have developed mechanisms to transition between freshwater and saltwater environments (David, Hamer, and Collier, 2009). They both employ the amphidromy category of diadromy, with adults living in freshwater and usually breeding annually, and juveniles spending three to six months in the ocean to develop before returning to freshwater to breed (Joy and Death, 2013). This migratory behaviour means that to carry out both their ocean and freshwater lifecycles the fish must move through the pipes from the sea to reach the headwaters. They are also both facultative, meaning that not all individuals must migrate, and therefore some of the fish may be relict self-sustaining populations that pre-date the piping of the Waimapihi (Joy and Death, 2013). However, it is likely that some fish are migrating to sustain the populations that exist in the headwaters today.
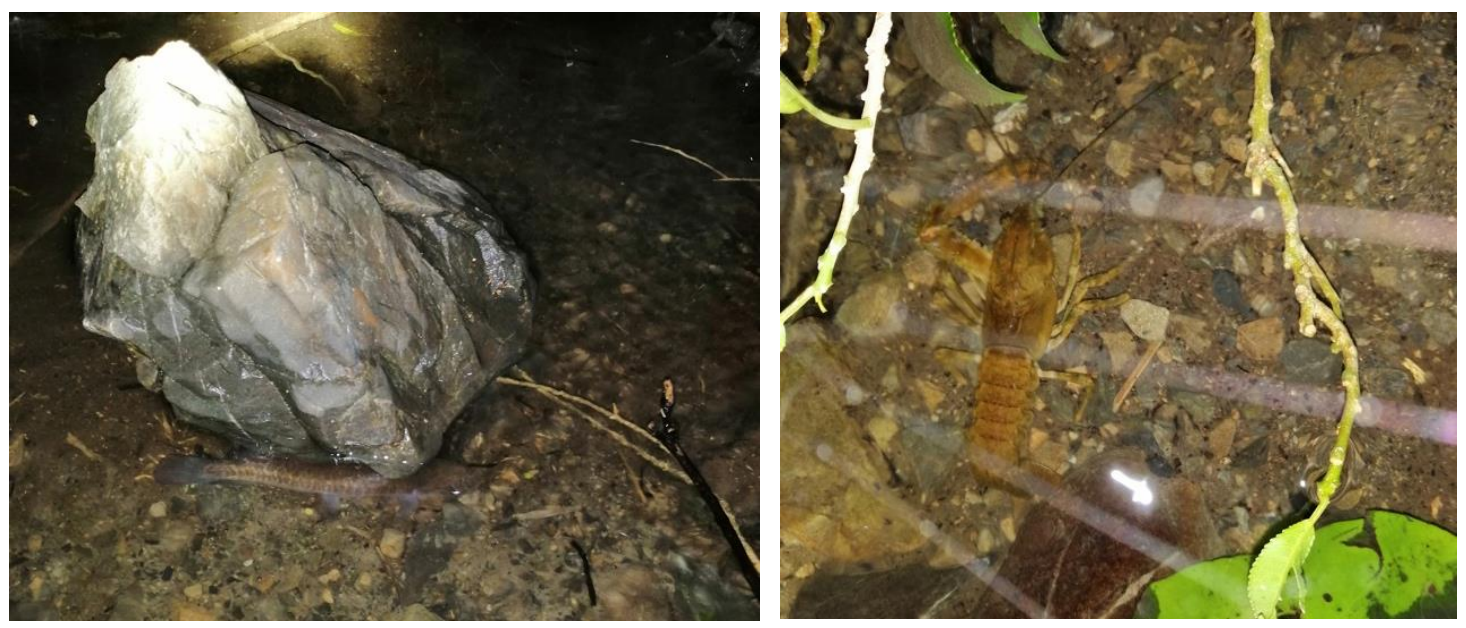

Figure 17: Images of banded kōkopu (left) and kōura (right) taken during spotlighting.

Banded kōkopu and kōaro adopt similar locomotory behaviours and are considered to occupy two classifications of swimming ability. They are classified as anguilliforms, meaning they can worm their way up through interstices in stones or vegetation, either in or out of water because they can respire in atmospheric oxygen if they remain wet (Boubée, et al., 1999). Additionally, they are classified as climbers because they can 
climb wetted margins of waterfalls, rapids, and spillways. They have developed features for climbing, such as roughened "sucker like" pectoral and pelvic fins, that enable them to adhere to rocks using surface tension to scale vertical drops. Kōura are also considered excellent climbers due to their legs. Bob stated that this climbing ability means that "you've got the crayfish, then the two whitebait species, they are actually the good climbing ones ... you just get the climbing species coming up through Waimapihi and nothing else" (Interview with Bob, 18 July 2019). Frances expanded on this suggesting there would have been more species in the stream "if we had no pipes whatsoever right, pre-European, we would have Inanga ... we would have Bullies. There would have been way more species here" (Interview with Frances, 25 July 2019). Having an understanding of what the fish populations would have been like before the pipe is important to understand its current state and how fish interact with it. Attending to fish in this way focuses the examination on the qualities and behaviours of fish, on individuals and groups, on single species and ecosystems, and on bodies and how they interact with their surroundings (Gibbs, 2018).

The most diverse and abundant fish communities in Aotearoa-New Zealand tend to occur in small coastal streams, such as the Waimapihi (David, et al., 2009). However, the presence of the pipe impedes fish movement up to the Waimapihi headwaters so there are fewer fish than would normally occupy a stream of this forest cover and this proximity to the coast (David and Hammer, 2012). Frances articulated that the barrier of the pipe meant that the habitat in the Waimapihi headwaters was underutilised:

I see habitat in Polhill underused because it is so hard for fish to get there, and I suspect the Waimapihi is underutilised as well, because there are heaps of insects in the bush in the two valleys, lots and lots and lots of insects and plenty of drift food. There's really good macroinvertebrates when you pick up all the rocks and have a look. There's lashings of food, there's lots of nice little debris dams and places for them to hide in the day, and good forest cover too. So you often see bandeds out in the daytime even (Interview with Frances, 25 July 2019). 
Woodford and McIntosh (2013) demonstrated that this presence of galaxiids, such as banded kōkopu, in the daytime was due to an absence of trout who are daytime visual feeders and predate on galaxiids. Trout are not good climbers unlike galaxiids, therefore, barriers such as the pipe restrict trout movement, acting as a protection for galaxiids. Consequently, there are some benefits from the pipe acting as a barrier in this way to protect some Indigenous species. The interactions of the various fish with the pipe is more complex that just "the pipe is bad for fish", and acknowledging that the pipe interacts differently with different individuals, such as different species, age, or size of fish, demonstrates that you cannot consider the fish as a collective. Understanding the behaviours of endemic versus introduced fish species is important when investigating biodiversity in a buried stream (David and Hamer, 2012). Frances described how you cannot consider parts of the stream in isolation, there is generally good habitat in the headwaters, however the extent of use of that habitat by fish is influenced by the lower piped reaches of the stream, which in turn can keep out predators. This is a pertinent example of the importance of holistic conceptualisations of streams that focus on integration, interdependencies, and interrelations occurring between water, soil, flora, fauna, infrastructure, and people in the Waimapihi (Tipa, 2009). The pipe has a crucial role in how the development of the ecosystem of the Waimapihi headwaters, and if we are to improve the biodiversity within the Waimapihi, and enhance the lives of the fish, then the piped section cannot be ignored. Furthermore, this demonstrates that some of the greatest gains in biodiversity would occur by improving fish passage in low elevation coastal culverts, such as the Waimapihi (David, et al., 2009).

\subsection{Fish Movement in the Pipe}

The presence of the pipe drastically impacts upon the connectivity of stream systems and the passage of fish due to their migratory life cycles (Wild, et al., 2011). It is not just the pipe that impacts the fish, but the water within the pipe, the flow and quality of the stream and stormwater has significant impacts on the survival of fish in the pipe (Wild, et al., 2011). Myfanwy said "it [stormwater] is the biggest challenge that we face in terms of our biodiversity here" (Interview with Myfanwy, 2 September 2019), because as Frances 
said "they [streams] are the life veins of the biodiversity of the city" (Interview with Frances, 25 July 2019). This section examines the presence and movement of fish in the piped section of the Waimapihi, and the implications of the pipe and policy on the fish.

Ben described the water flow he saw when he was in the pipe for repairs, saying that "there is actually a considerable baseflow that flows through it ... calf-deep probably, so there is a fair amount of flow that goes through it" (Interview with Ben, 19 September 2019). Piped streams have a high velocity flow, due to the narrowing of the channel, increasing the slope, and the uniform structure of pipes (Amtstaetter, et al., 2017). Ian, owner of Mark Kendall Shoes, stated that "they'd have to go against the current" (Interview with Ian, 22 August 2019), and often this increased flow exceeds swimming capabilities of galaxiids: to make any progress upstream they must swim faster than the downstream flow velocity (Mitchell, 1989). These features of piped streams lead to an absence of low-velocity zones for fish to rest during their journey (Boubée, et al., 1999). However, research by Mitchell (1989) demonstrated that banded kōkopu can rest between swimming attempts in high flow water by swimming to the bottom, where water flow is slower than the middle due to friction. Here they flex their pectoral and pelvic fin muscles to engineer a down thrust from the water flowing above them to hold them in place. Such adaptation enables resting without loss of position between bouts of burst swimming, permitting these species to negotiate water velocities impassable to species relying solely on swimming. Exploring the bodies of the fish in this way enables an understanding of how they confront the challenges they must face when moving through the piped section of the Waimapihi (Buller, 2015).

Most of the participants mentioned the length as a feature of the pipe impeding fish passage. If the length of the pipe exceeds the distance a fish can swim in one burst, and there are no resting places within the pipe, then they can become exhausted before they reach the end and not be able to pass through the pipe (Boubée, et al., 1999). Another feature is the gradient of the pipe, which Ben mentioned: "they must have migrated up the pipe, that is amazing, cause Aro Street will be a really steep culvert" (Interview with Ben, 19 September 2019), which increases the flow of water that fish must swim against 
(Paul and Meyer, 2001). Figure 18 shows the elevation profile of the Waimapihi pipe and demonstrates that the upper reaches, the last kilometre that the fish would have to swim (when they are their most tired), is the steepest. Additionally, the materials of the pipe influence the ease with which fish can move through the pipe. Materials that are not smooth and uniform increase friction so reduce the water flow, produce low velocity zones for rest, and provide features for traction during climbing and hiding places from predators (Boubée, et al., 1999). Bob discussed the benefit of the bricks that the pipe is made of, "it's an older pipe system so a lot of it is built with bricks so it's really rough, they can climb on and hide in" (Interview with Bob, 18 July 2019). While Ben compares that to the top section made of concrete, "I think the top section of that is a concrete pipe and not a brick pipe, so it must be pretty smooth on the inside" (Interview with Ben, 19 September 2019). Exploring how the pipe materials have the capacity to act, alone or in alliance with the fish and water, illuminates some of the ongoing more-than-human interactions occurring in the Waimapihi (Gillon and Gibbs, 2019). 


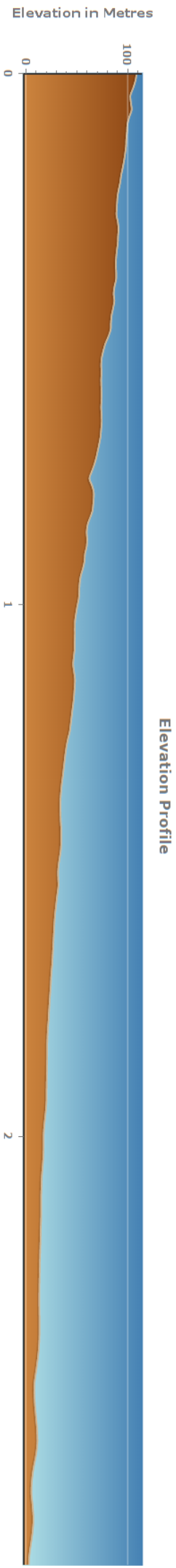

Figure 18: Elevation profile of the Waimapihi pipe (top end at the Reserve and bottom at outfall), showing that over the approximately $2.5 \mathrm{~km}$ of pipe length the elevation rises to $100 \mathrm{~m}$ above sea level. Adapted from Water and Drainage-LocalMaps, by WCC, 2019, Retrieved from:

https://gis.wcc.govt.nz/LocalMaps/Viewer/?map=57fb534c2174471ca485132112088afc 
It is not just the water flow but the water quality that impacts fish presence and movement, Ben remarked that "they have not just the physical barriers ... but the water quality can't have been that great going down there” (Interview with Ben, 19 September 2019). Contaminants in stormwater that enters the pipes, such as heavy metals and hydrocarbons, have health impacts for the fish, reducing their ability to pass safely through the pipe to the headwaters (McEwan and Joy, 2009). Phill demonstrated the importance of considering the water within the pipe when he suggested that it should be considered as the habitat of the fish.

I would say that water is seen as the habitat, is a living habitat. We often think of a streambed as the habitat but actually water itself, if you are a fish, is the three-dimensional space. It's like air, for us it's air, for a fish it's water, it's the three-dimensional space in which it lives. And then there is the form of the habitat, which is either the pipe or the stream (Interview with Phill, 2 August 2019).

Taking a hydrosocial approach, Phill here is examining the interplay between the social interactions in the fish, the infrastructure in the pipe, and the flow of water, and how they interact to produce the Waimapihi Stream (Linton and Budds, 2014). All of these features of the pipe, and the water flow and quality within, influence how well fish can move through the pipe to reach the headwaters. Ian sums it up by saying "So these things [fish] have to contend with all of that. It's interesting though, because life is just so virile isn't it, it is everywhere" (Interview with Ian, 22 August 2019). Ian described how prevalent life is, even stuck underground in a big pipe, with no sunlight, and lots of contamination.

The fish representing the presence of life in the pipes was a common thread in the interviews, Ian articulated this when he said "well it is interesting for me because fish is just, it brings life to the whole thing, so it is not a dead stream it's actually got life in it, it's a habitat" (Interview with Ian, 22 August 2019). Many of the other participants spoke about it being dead water when it was in the pipe, and that it did not seem like a stream when it was in the pipe. However, some participants did mention that they had always thought the stream was alive in the pipe. Ra said "oh no, I always thought that the water was still good even though it was coming through drain pipes and it's just vindication in 
that kind of sense, to find little critters in there is awesome" (Interview with Ra, 23 July 2019). While, Rachel said that this presence of life meant that we had to work harder to protect the stream, "that means that there is life in there, ... we have some responsibility and obligations to it to maintain its health" (Interview with Rachel, 29 August 2019). The presence of life meant different things to different participants, but for all of them it did influence how they understood the piped section of the Waimapihi and how they thought it should be treated. The presence of fish life in the pipe was linked to how people connected to the Waimapihi, knowing there was life in the piped stream was something for people to connect to. It also engendered a curiosity about how and why the stream had been buried and the impact of that on the fish. GWRC did an exhibition for Matariki in 2019 called Ahi Kāa, they collected fish they found in piped streams in Miramar and put them in tanks in an exhibition down on the waterfront to show people what lives in buried streams. Phill discussed some people's responses about the fish being in the pipes:

And that is just a simple way to create connection, and in the stall we had 'the fish beneath your feet' and we heard a three year old ask their parents 'how did the fish get under the ground?'. Because it is a bit of a strange way to put it 'fish beneath our feet', talking about urban streams and that is kind of confusing, so "the fish swim through the ground or how does that work?' until they start to realise we piped these (Interview with Phill, 2 August 2019).

Looking at the fish that had been in pipes encouraged people to ask questions and consider the impacts of burying the Waimapihi, and other streams, on fish, people, and the city. A hydrosocial approach encourages us to ask questions because it makes us consider the interactions between fish, humans, the water, and the pipes that are often not considered, and makes us critique the status quo (Palomino-Schalscha, et al., 2016).

As mentioned in the previous chapter, the water in the pipe is not considered a stream legally under the RMA (1991), which has consequences for the fish that move through the pipe. If the piped section of a stream is not considered a stream, then the ecosystem does not legally need to be protected. Bob highlights how the law influences the fish and 
how their habitat is protected, but also how our human laws are limited when it comes to fish.

Under the Resource Management Act, they're not considered streams once it's in a pipe, but still that was a stream, the fish don't know that it's not a stream under the law. But that is still important to provide that linkage for fish up to those surface stream systems because we have the objective of improving or maintaining ecological health in what we have. You need to make sure they are getting through there (Interview with Bob, 18 July 2019).

The disjunction in legal definition of the Waimapihi, with its piped section, is inconsequential to the fish in some ways because they move through the piped section to reach the headwaters completely oblivious to our human conceptions of streams. However, the disjunction does have impacts on the fish in other ways due to the influence it has on how humans treat the Waimapihi, including the influx of contaminants and runoff that enters the pipe as stormwater. There are legislative tools in the RMA (1991) and the Freshwater Fisheries Regulations (1983) that state that provisions must be made for protecting fish passage in a culverted stream (David, et al., 2009). Part IV of the Freshwater Fisheries Regulations (1983) state that: "no dam, diversion structure, culvert, or ford shall be constructed in such a way that the passage of fish would be impeded. Where it is necessary, a fish pass must be provided." However, the complication is that the Waimapihi was piped so long ago, in the late 1800s, when these provisions were not in place, so few provisions were made for fish passage when the stream was piped. Additionally, the piped section is so long and old that it is hard and expensive to enter to monitor and maintain the fish passage effectively. Frances described how structural maintenance on the pipes for flood protection often takes precedence to maintaining fish passage, which could have dire consequences for the movement and survival of fish.

Once it's in a pipe the RMA says it is not a river. And I really struggle with that, because how are we going to keep all these stormwater drain guys down there tidying it up, getting the gravel out, straightening it. But what else are they doing, are they blocking fish passage? It could be a disaster (Interview with Frances, 25 July 2019). 
Frances highlights how fish are not the main priority when work occurs on the pipe, due to the lack of legal protections under the RMA (1991) for buried streams and the fish within them.

\subsection{Enhancing Fish Passage in the Waimapihi}

\section{Stream}

After discussing the current impacted state of fish passage in the Waimapihi, the participants examined future improvements that could be made to the pipe to enhance fish passage. Amtstaetter, et al. (2017) discussed the importance of enhancing fish passage to ensure the survival of diadromous fish, such as kōaro and banded kōkopu, that rely on migration for their lifecycle. The presence of a piped section of a stream is an impediment to fish passage, primarily due to the increased water flow. However, fish passage structures can be installed to mitigate the impacts of the pipe and improve migration (Wild, et al., 2011). As mentioned in the previous chapter, if only some sections of the Waimapihi were going to be daylighted in the future, then there would be remaining piped sections for fish to move through. Therefore, these sections will need to be retrofitted to ensure fish can pass through them easily to reach the headwaters during their migratory behaviours (Amtstaetter, et al., 2017). The objective of fish passage designs must be to make upstream passage as easy as possible (Mitchell, 1989). This section examines the potential option of enhancing fish passage in the piped section of the Waimapihi into the future, exploring some of the options to retrofit the pipe and some of the limitations to carrying out this work.

The Waimapihi will likely remain piped in some areas for the foreseeable future, therefore retrofitting existing piped streams will have to be a part of urban stream management into the future (Franklin, et al., 2018). There was general agreement that there was an inevitability about some of the Waimapihi remaining in pipes, and so the focus on those areas needed to be fish passage, which Bob described. 
It'd be good to look into what you can do to actually help fish get up through there, because I guess the way it is now, that pipe is always in reality. In a lot of sections of it, it's probably going to be there because there is a road on top of it. But what can you do to help the fish get through there? (Interview with Bob, 18 July 2019).

Accepting this inevitability of some pipes remaining will enable the focus to move towards exploring creative options to enhance fish passage into the future (David and Hamer, 2012). If fish passage is taken seriously then the fish will have agency to dictate how money is spent on the Waimapihi, because their behaviours will be the focus of research and design of structures to enhance their passage (Bear and Eden, 2011).

Using the hydrosocial approach and considering the interaction between the various more-than-human entities, such as the pipe and the fish, encourages examination of practical components such as the structure of the pipe and how that influences the movement of fish (Gillon and Gibbs, 2019). A stream management approach that takes into account fish agency, infrastructure, social systems, and the fluctuating relationships between them, raises interesting possibilities for the future of the piped section of the Waimapihi. Thus far, in this chapter I have explored the materiality of the piped section of the stream, examining the complex ways that the pipe inhibits fish migration and some of the ways fish successfully move up the pipes. Simultaneously, introduced fish that predate on banded kōkopu and kōaro are unable to swim up the pipe, protecting the Indigenous fish communities in the headwaters. Human interactions with the piped section shape, and are shaped by, these fish interactions - shifting human perceptions of the liveliness of the piped Waimapihi, but also facing constant threat from infrastructure "improvements" or neglected water management. A more-than-human approach highlights the numerous, often forgotten, agents within the Waimapihi stream. A hydrosocial cycle approach draws on these many agents, alongside the waterflow, infrastructure, and social policies and perceptions to understand what the Waimapihi is at any particular moment. This approach also highlights the diversity of possible futures for the Waimapihi Stream as any of these aspects of the stream shift. For example, the piping material is changed, parts of the stream are daylighted, community knowledge of the piped stream increases, or policy changes, etc. 
The pipe replaces the natural varied habitat of a stream with uniform artificial conditions without natural substrates, therefore, alterations to the pipe need to be made, including baffles, weirs, and ropes (figure 19), that roughen the surface to replicate this natural variation (Amtstaetter, et al., 2017, Franklin, et al., 2018). Frances discussed how the fish often need a textured surface to climb up a pipe, "the piped bit, it needs gravelly bits in it, you can't just keep it pristine clean. We can stop this housekeeping stuff, messiness is ok". She mentions that understanding that the pipe is a fish habitat means embracing "messiness" to provide habitat heterogeneity similar to the structure of a stream bed (Neale and Moffett, 2016). Furthermore, these fish have benthic behaviours meaning they rest on the bottom of the streambed, often living below the streambed in the spaces between rocks and boulders, and so require this messiness to fulfil these behaviours (Joy and Death, 2013). Added features create a roughened surface that disrupts laminar, homogenous water flow to reduce what fish must swim against and provide refuge places for swimming fish (David and Hamer, 2012). Mussel spat ropes have been shown as cheap and effective at enhancing fish passage of climbers, such as kōaro and banded kōkopu, in piped streams, and therefore, offer a potential interim solution (David and Hamer, 2012). Understanding fish behaviours within and between species, such as their ability to climb on different materials, is essential to making successful alterations to enhance fish passage in a particular stream (Amtstaetter, et al., 2017). Phill expanded on this when he talked about creating variety in the habitat for the fish when he said:

Being willing to put a textured surface in the pipe. Basically realise your pipe is actually a habitat and so what are the simple but meaningful modifications you can do, like if you put little rock gabions that are concreted into the pipe, to create those hiding places, those refuge places for the fish (Interview with Phill, 2 August 2019).

Describing the pipe as a habitat highlights the role of fish in producing meaning of the pipe: without fish it would just be a pipe, not a habitat (Gibbs, 2009). Furthermore, this understanding of the pipe as a habitat has implications for policy and management of the pipe and stormwater as it highlights how legislation is failing to provide a level of protection required for Indigenous fish under the RMA (1991) (Franklin, et al., 2018). As described above, there is variation in the materials that the pipe is made of. The lower 
section is older brick, but the upper section has been more recently repaired. It is smooth concrete where it is steeper, at the end of the swim, and therefore, the focus of retrofitting should be on this top section that presents the greatest challenge to fish passage. 

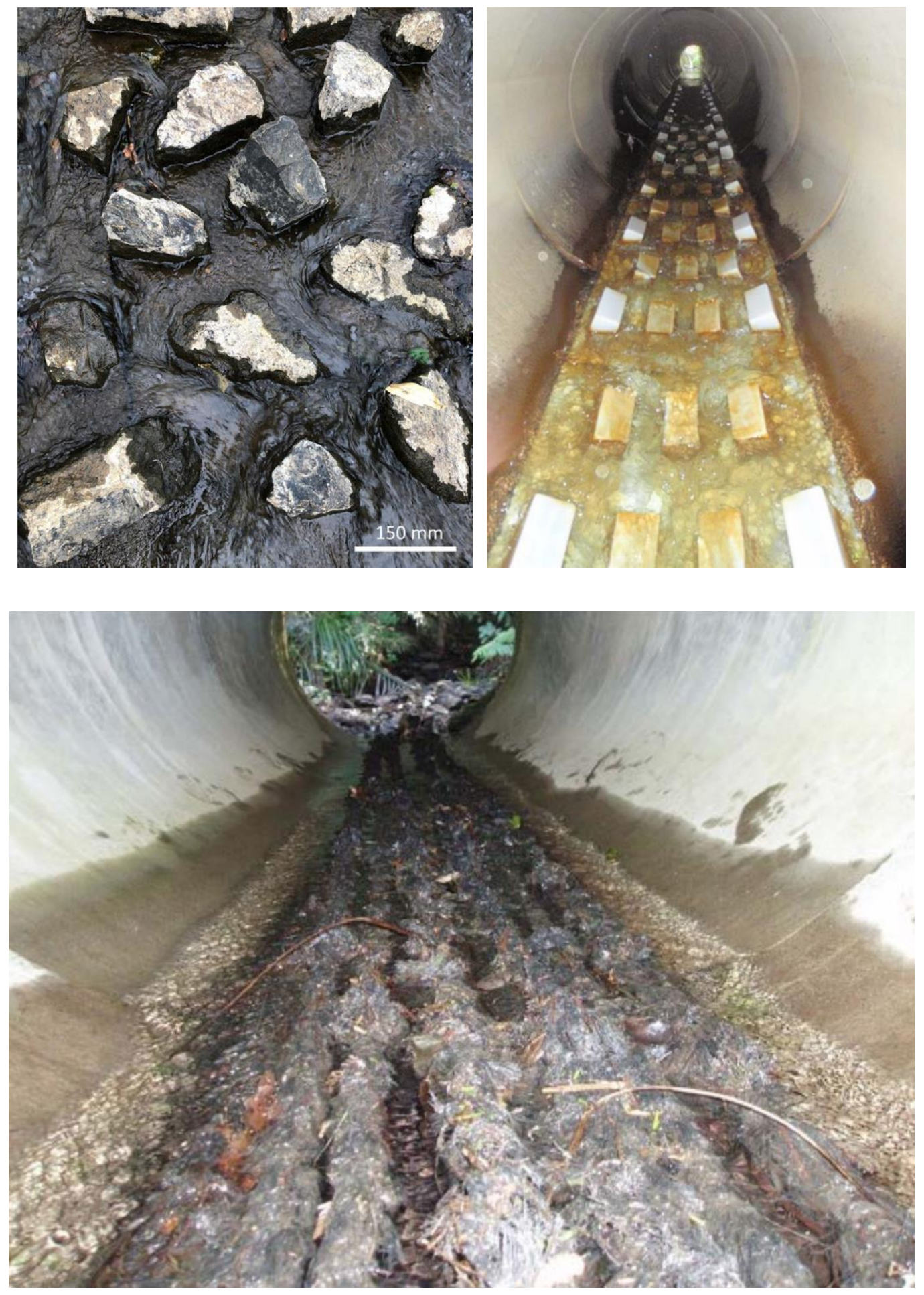

Figure 19: Images of possible retrofitting options, top left: rock spacing on a weir, top right: spolier baffle sheet, bottom: mussel spat rope. Reprinted from "New Zealand Fish Passage Guidelines For Structures Up To Four Metres" by P. Franklin, et al., 2018. Te Whanganui-a-Tara-Wellington, Aotearoa-New Zealand: National Institute of Water and Atmospheric Research. Retrieved from https://niwa.co.nz/static/web/freshwater-and-estuaries/NZFishPassageGuidelines-upto4m-NIWA-DOC-NZFPAG.pdf 
The pipe has many roles: as stormwater, for flood protection, and as a habitat for fish. However, the latter has often been neglected, with little thought being given to fish passage in their development and maintenance (Boubée, et al., 1999). The ageing nature of the pipes and the growth in the city means more stormwater capacity is required into the future (Franklin, et al., 2018). The process of increasing the capacity for water flow has already begun, with additions to the pipe such as surge chambers and weirs. However, yet again these works have neglected fish passage, so alterations have needed to be made after the work was done, as discussed by Frances:

The pipe from Polhill Stream comes out quite high above the water and then the water just flows down a vertical wall to reach the water. And they [WW] said fish couldn't get up there and I said well fish have got up there, but we need to make it better... and sounds like you'll need to stick some mussel spat rope in there to do something to make sure fish can easily get up out of the surge chamber. We don't want fish trapped in the surge chamber (Interview with Frances, 25 July 2019).

This example shows that fish passage had been an afterthought with this structure, and highlights that more than the flow of water needs to be considered before these pipes are designed and upgraded, and that the fish that move through the pipe must be at the forefront (Franklin, et al., 2018). Frances mentioned that the future growth of the city would likely lead to more of these structures and warned that fish passage needed to be a requirement that was incorporated into the designs before construction occurred. Taking a more-than-human approach to considering future work on the stream would raise the importance of the use fish have for the stream, both the open and piped, so that fish passage and health would be the focus of any work done on the Waimapihi (Buller, 2015). This alongside a hydrosocial approach to considering the Waimapihi will enable the changes in fish passage to be examined into the future (Linton and Budds, 2014). 


\subsection{Conclusion}

The social component of the hydrosocial cycle includes fish when using a more-thanhuman approach (Cousins, 2017a). Therefore, understanding the role of fish in defining, adding value to, and producing a stream is required when trying to understand the Waimapihi under a hydrosocial lens. Taking a more-than-human approach enabled the exploration of the interaction of the fish with the built environment of the pipe and the city (Gillon and Gibbs, 2019). The examination of the bodies of fish is an example of the more-than-human approach taken, which informed the exploration of the perceptions of the fish in the pipe, not just those of humans. This involves looking at the characteristics of the bodies, such as the fins and legs, and how they influence fish movement in the Waimapihi (Bear and Eden, 2011). This approach places the fish as part of the social interactions occurring in the stream and considers the influence of the materials and structure of the pipe on the movement of fish through the pipe (Gillon and Gibbs, 2019). These physical features of the pipe determine the water flow and quality against which the fish must swim in their migration towards the headwaters (Boubée, et al., 1999). To imagine the pipe from the fish's perspective exemplifies the more-than-human idea of "thinking like a fish", to explore what they see, hear, feel, and taste as they migrate up the piped section of the stream (Bear and Eden, 2011). Considering how the fish experience the piped stream allows us to see that there are limits to our understanding, and that we are only one of many entities that experience and have knowledge of the Waimapihi (Yates, et al., 2017).

The changing interactions between the fish and various components of the Waimapihi, including the headwaters and the pipe, highlights the important role fish have in defining a stream. A part of this role was bringing life to the "dead" pipe and encouraging people to connect to the piped section of the Waimapihi. The interaction of fish with policy around freshwater and stormwater management highlights how disjointed policy currently is. This exemplifies that fish need to be incorporated more effectively into it in the future. Furthermore, any retrofitting that takes place must be monitored to assess its effectiveness and success at improving fish passage, otherwise actions taken could have 
negative impacts, or could lead to complacency and inadequate improvements being made (Franklin, et al., 2018). This demonstrates the agency fish should have in the policy around buried streams and the design of stormwater pipes. These pipes are the site of complex social interactions between the social power of institutions that control them and the fish that move through them. Taking a hydrosocial lens with a more-than-human approach to exploring the waters of the Waimapihi Stream allows for a more nuanced understanding of all the components interacting and an in-depth exploration into the role of fish in an urban stream (Linton and Budds, 2014). 


\section{Chapter Six: People's}

\section{Connection to the Waimapihi}

\section{Stream}

\subsection{Introduction}

A hydrosocial approach involves examining the social component of water alongside the physical flow and the infrastructure when trying to understand what makes up a waterway (Linton and Budds, 2014). Key to this is understanding the connections people have to waterways, how they are limited or enhanced by infrastructure such as pipes, and the ways people try to overcome these barriers. Stream burial involves rerouting the waterway underground into pipes, this has severed people's connection to them, impacting how they interact with and value them (Kaïka and Swyngedouw, 2000). If streams are buried long enough people forget or do not know of their existence at all (Gibbs, 2014). Forcing stream flow underground renders it invisible and limits people's understanding of the properties of the water, what volumes, densities, masses, or qualities flow through the network (Cousins, 2017b). Additionally, water is silenced when it is forced to flow through pipes underground, it is rendered mute in comparison to the sound of an open stream, the rushing of water and sound of insects and other wildlife (Kaïka and Swyngedouw, 2000). When a stream is hidden underground, taken out of sight, and is silenced, it changes how water is perceived and renders it a resource to be exploited (Kaïka and Swyngedouw, 2000). The burial of the Waimapihi Stream has taken away people's ability to see it and interact with its waters on a regular basis, therefore, people have had to find alternative ways to connect to it. This section explores people's connections to the piped section of the Waimapihi Stream: the impacts of burial on these connections, the ways people have tried to reconnect to the buried stream, and the potential ways to raise awareness of and engage with the stream into the future. This 
chapter explores the cultural and social practice of interaction with water and water places (Gibbs, 2014).

\subsection{Buried Waimapihi}

The Waimapihi's current state is predominantly underground, flowing underneath central Te Whanganui-a-Tara-Wellington. Participants responses to this buried state included: that they did not know about the stream, that it felt wrong for the stream to be buried, and that the burial of the stream has made it hard to connect to. Most of the participants had heard of the Waimapihi, but this was because I chose participants who had worked with the Waimapihi, including from GWRC, WCC, WW, or artists who had created pieces related to the Waimapihi. Additionally, I chose residents of Holloway Road or Aro Valley who lived near the open section of the Waimapihi. However, they associated the Waimapihi mainly with the open section, at the top of Holloway Road, and not the piped section. In fact, none of the participants knew the exact path of the Waimapihi or where it enters the Harbour, except for Ben who works at WW in stormwater, and therefore, works with the pipe. These responses demonstrated that understandings of what a stream is tend to be confined to an open flowing waterway rather than in a pipe (Wild, et al., 2011). Therefore, this chapter will delve into how participants understood the piped section of the Waimapihi Stream, taking a hydrosocial cycle approach to explore the impacts of the pipe infrastructure on the Waimapihi and people's perceptions of it.

Three participants, Sandra, Christina, and Ian, owned shops over the Waimapihi pipe. Of these three, Sandra had heard of the Te Aro Stream, not Waimapihi; she had been to its headwaters in her childhood but was not sure where it flowed under the city and outlet into the Harbour. Christina had been to the stream at the top of Holloway Road, but did not know what it was called or that it was piped under the city. While Ian, who had worked in or owned the shop over the pipe for 52 years, said he had never been to the top of Holloway Road and had "never heard of it [Waimapihi] until you said" (Interview with 
Ian, 22 August 2019). This demonstrates how easily people can live, work, and move around the central city without encountering the Waimapihi Stream at all. Ian succinctly articulated that the burial of the stream removed it from people's view and knowledge, saying the stream was "out of sight, out of mind" (Interview with Ian, 22 August 2019). These examples highlight how for people to have an awareness or understanding of a stream they tend to need to see it (Poe, et al., 2016).

Those participants who did know about the Waimapihi discussed how they felt that it was hard to connect to the stream because it was piped underground away from people's immediate consciousness. Lily described how the urbanisation of the area has disconnected people from the form of the landscape and the place of water in it:

Here's the grid and how the hell does the water fit into that, and so it just becomes really fragmented. But I guess the scary thing is not that that has happened but the point that it affects how you read the landscape (Interview with Lily, 24 July 2019).

This demonstrates how the built environment of the city and its structure has changed people's perceptions of water and the Waimapihi, impacting how they connect with and understand it (Gillon and Gibbs, 2019). Myfanwy expands on this idea when she describes how the burial of the Waimapihi has meant that when people think of urban streams in Te Whanganui-a-Tara-Wellington they do not immediately think of the Waimapihi because it is out of sight and forgotten.

The Waimapihi Stream, it is one of our small urban streams, it probably isn't one of our streams that has a whole lot of people connected to it. It starts up in Polhill Reserve and then the majority of it is then piped. So yeah, unlike some of our streams, like the Kaiwharawhara, which I think people are more connected to it, possibly a little bit more forgotten. I think it's the groups that work up around Polhill Reserve that actually have a connection to it. So I guess you'd describe it as one of our very typical urban streams, given that it's headwaters are slightly hidden and most of it is in pipes and comes out in the Harbour (Interview with Myfanwy, 2 September 2019). 
She described how people's connection with the Waimapihi changes along its length, because of the piped and open sections. Where people can interact with the Waimapihi is in the reserve, doing restoration and pest control work, so they can build a connection with it, however this is limited for the piped section. This is significant as it shows that our understandings of streams, and water, are influenced by the infrastructure they flow in. This infrastructure mediates how people interact with streams, and therefore, their burial removes that interaction and disconnects people from streams (Wild, et al., 2011).

The participants described feelings of sadness and anger about the buried state of the Waimapihi. Rachel explained how the burial of the Waimapihi made her sad about its disconnection from the sunlight:

Water is a major, has enormous spiritual value for my family ... It harbours life, it carries life, and as long as it is moving it maintains its mauri. It feels sad for it to be covered over, actually to be honest, and that the sun can't reach it (Interview with Rachel, 29 August 2019).

Rachel describes her family's spiritual connection to water, and the life within it, which informs her sadness at the disrespect it is being shown being buried. She mentions the liveliness of water, that its mauri is maintained with flow, but that removing it from the surface impacts upon processes in the stream. Lily expanded on this when she said, "putting it underground and trying to trap it down there just doesn't feel right to me" (Interview with Lily, 24 July 2019). She highlighted the forceful nature with which the stream has been treated when she said it had been "trapped" underground. This demonstrates the emotional connection that people develop towards local places that inform their cultural and personal identity (Tipa, 2009). People have connections to different parts of the landscape for various cultural, social, or spiritual reasons, which informs how they interact with those features, which in turn shapes their identity (Poe, et al., 2016). Therefore, if these local places, such as the Waimapihi, are degraded then people's wellbeing is impacted; humans are a part of the stream's ecosystem (Tipa, 2009). Both participants articulated what others also said, there were generally negative feelings about the burial of the stream and that people had an emotional response, talking about it making them "sad" or it not feeling "right". However, not all the participants had negative 
feelings about the burial of the Waimapihi. Ra said his feelings towards the pipe and the burial of the stream had changed throughout the interaction he had had with it making the sculpture.

I mean obviously, you know maybe years ago, before anyone had conceived of the idea, it would have been a disastrous idea because it is a sacred waterway. But since it's happened, and it's been kind of recognised as a historical landmark and people kind of have got some sort of knowledge of the place. I think my feelings towards the culvert are good. I think through the process of making the carving I've discovered some sort of closure with the idea of this giant city being built over the top of fishing grounds, and ancestral and really important sacred sites and things, because you know now there is a bit of an awareness of that. And I think apart from hiding the stream from the light and everything I think it's still, if it's recognised and it's kept clean, and then it should still hold its, some kind of sacred significance. That's what it does for me (Interview with Ra, 23 July 2019).

He described how interacting with the piped stream had allowed him to rethink his feelings towards the burial of the Waimapihi, and that they were now more positive. This demonstrates the importance of encouraging people to interact with the piped section of the stream, so that they can evaluate their perceptions of the Waimapihi and the place of water in the city. Some of the positives he raised around the Waimapihi were it being recognised as a historic landmark and of the pipe potentially protecting the stream from pollution, acknowledging these allowed him to somewhat reconcile the burial of fishing grounds, ancestral and sacred lands. Although he did lament the fact that the stream was not receiving sunlight as Rachel had. These examples highlighted the nuanced interactions people have with the buried, piped section of the Waimapihi and how they can change over time, especially if people are able to interact with the stream and its history. 


\subsection{Alternative Ways People Have Tried To Connect to the Buried Waimapihi}

All the participants discussed how people needed alternative ways to reconnect to the buried Waimapihi because people's ability to connect easily had been impacted. Currently, there are three examples of physical markers along the piped section of the Waimapihi, that are attempts to raise the awareness of the underground stream, figure 20. Additionally, there are the stories that people tell about the Waimapihi, that help the connections to it to be maintained through time as they can be passed on between generations. The artworks were seen as an important facilitator of connection to the Waimapihi as they provide a focus and reminder of the stream. The materiality of the artworks provides a tangible connection for people and demonstrates how they have more-than-human agency to mediate people's connection to the Waimapihi, in particular its piped section. However, this is different to the connection facilitated by the fish because the art is not alive, so the connection is not to life but more the idea of the stream. This section explores some of the creative ways people have tried to reconnect to the buried stream, through art and stories, some of the protocols around doing this, the lessons learnt, and the perceived effectiveness of these approaches to reconnect to the Waimapihi. 


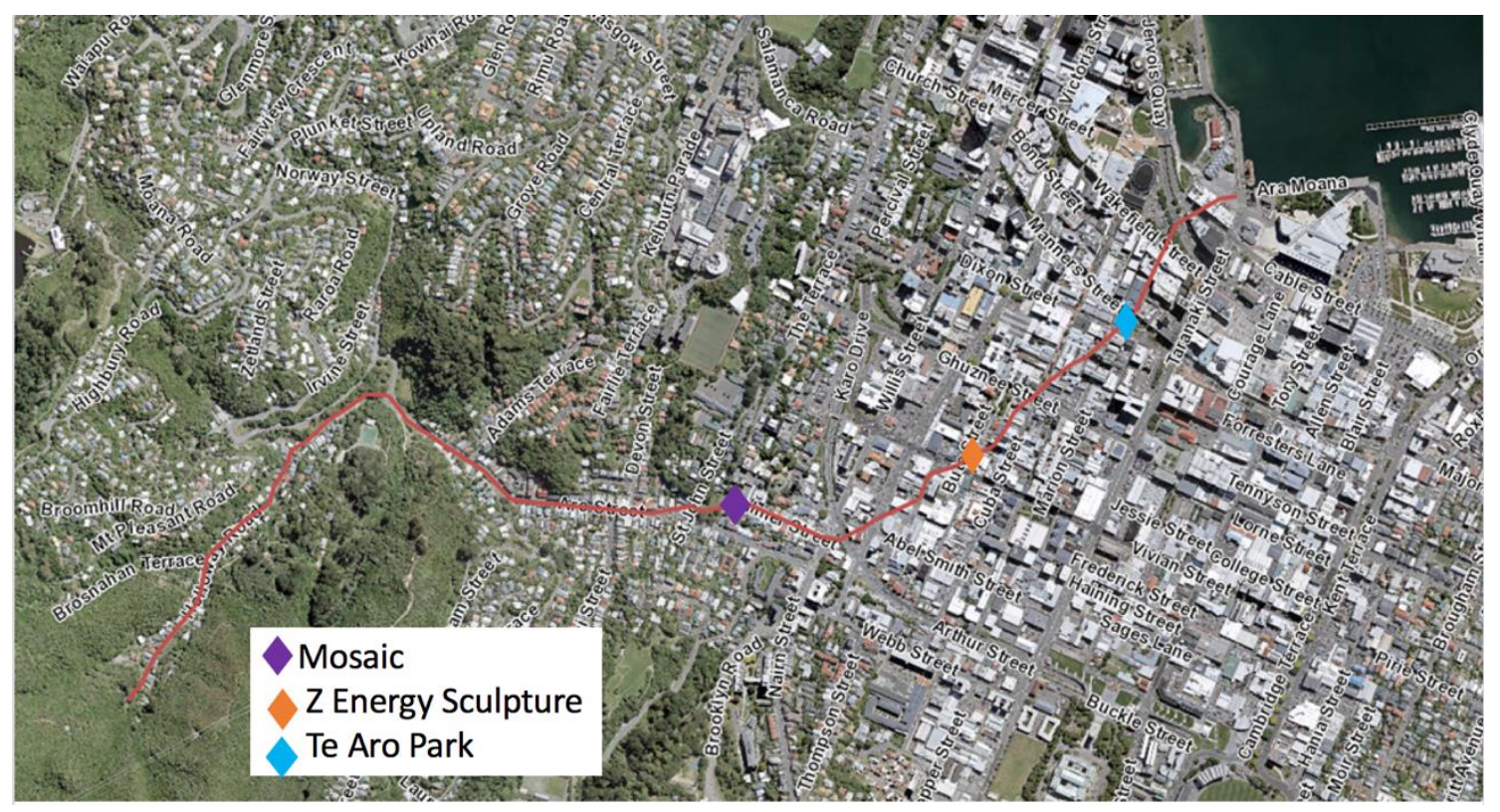

Figure 20: Map showing where markers are located along the path of the piped section of the Waimapihi. Adapted from Water and Drainage-LocalMaps, by WCC, 2019, Retrieved from:

https://gis.wcc.govt.nz/LocalMaps/Viewer/?map=57fb534c2174471ca485132112088afc

The first of the three artworks is a mosaic (figure 21) at Aro Valley Preschool created by Rachel Silver that depicts the rangatira Mapihi, who the stream is named after, bathing in the stream (Aro Valley Preschool, n.d.). The project involved consultation with mana whenua and was a part of a learning experience for the children of the preschool, who walked up the stream and learnt about its history (Aro Valley Preschool, n.d.). 


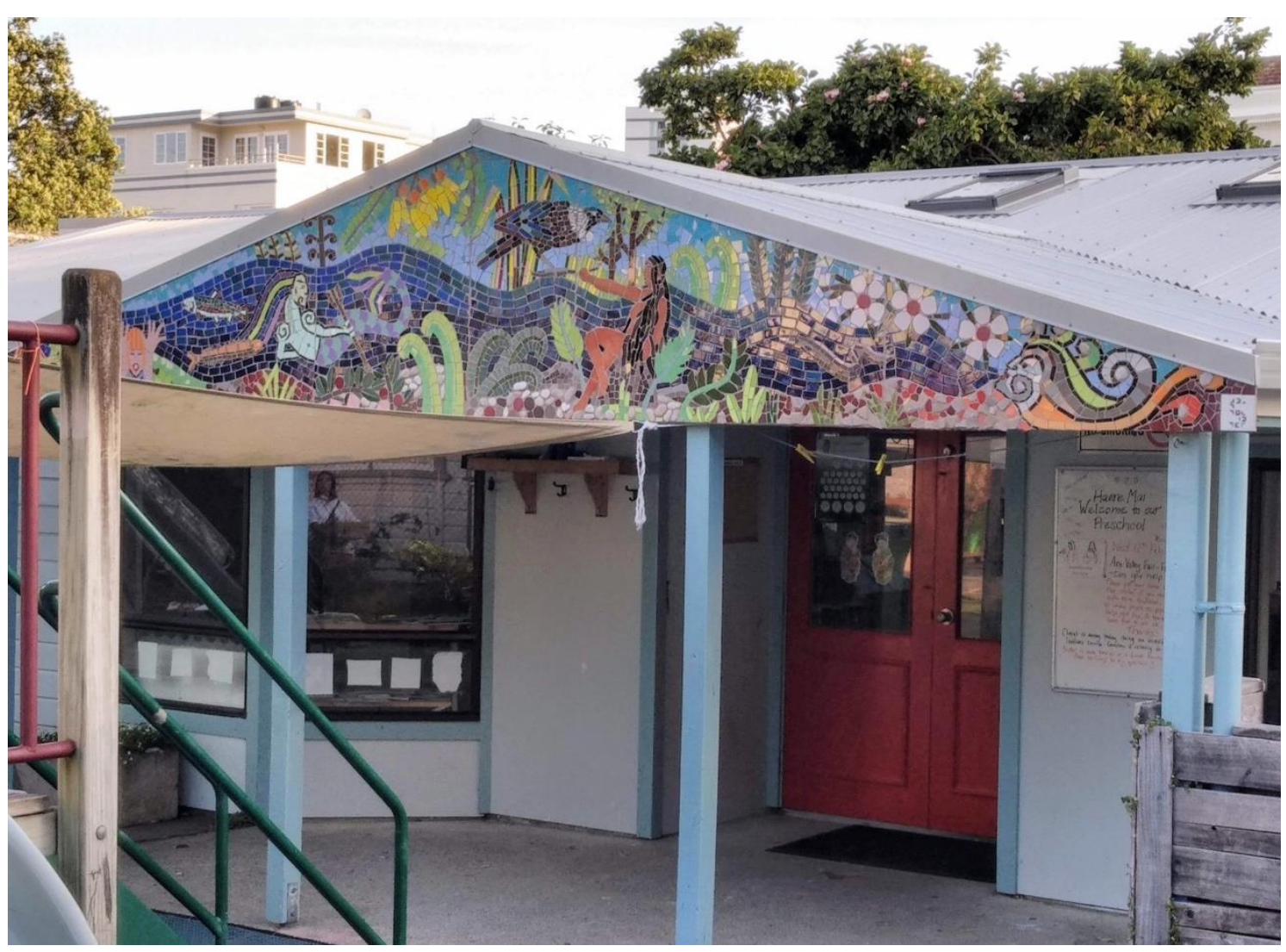

Figure 21: Image of mosaic at Aro Valley Preschool of the Waimapihi Stream.

Moving downstream, the second artwork is a sculpture (figure 22) at the Z Energy petrol station on Vivian Street created by Ra Vincent. The sculpture is made of the bricks from the 140-year-old original pipe that the stream flowed through, and a trail of blue koru to show the path the stream took before being rerouted around the petrol station (Z Energy, 2013). Z Energy and the Port Nicholson Block Settlement Trust partnered to produce this sculpture, which was developed to reflect the cultural and historical significance of the Waimapihi Stream (Z Energy, 2013). 

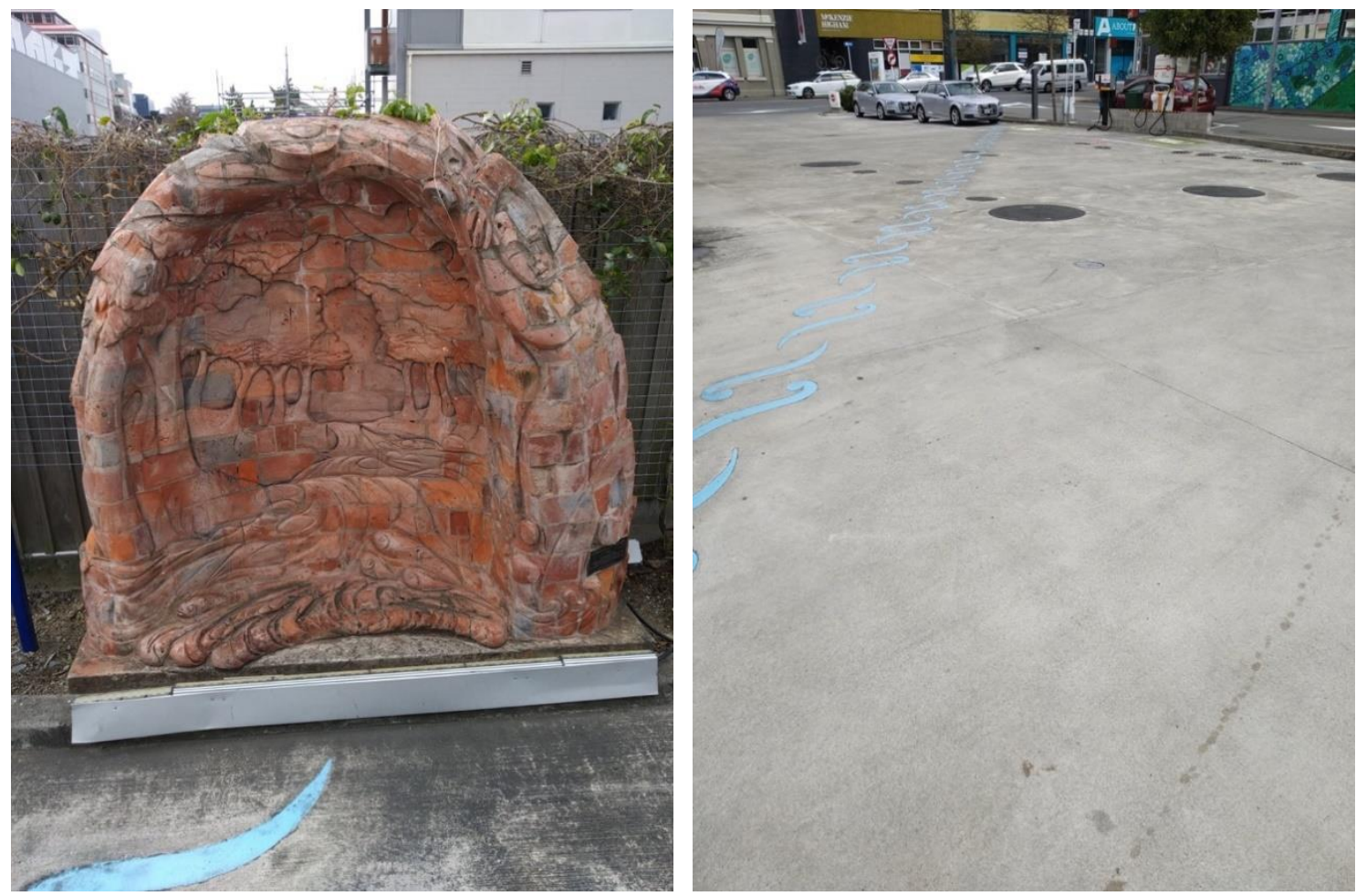

Figure 22: Image of sculpture made of Waimapihi pipe at Z Energy on right and trail of blue koru identifying original path of Waimapihi.

The final artwork is Te Aro Park (figure 23) created by Shona Rapira Davies, that sits on the site of Te Aro Pā (Meekings-Stewart, 1992). The park was created from clay tiles that the artist says have mauri and connect to Papatūānuku, it also has fountains that are meant to represent the Waimapihi Stream (Meekings-Stewart, 1992). The pools have paintings of women in the bottom (figure 24), the sign at the park reads "Female figures representing the three generations of women (old women, young women, and young girls). The water in the pools represents the life principles of cleansing, blessing, and renewing. The water flows diagonally across the site and reflects the Waimapihi Stream and original shoreline”. Additionally, there is a list of the buried streams in the city on some tiles in the park (figure 25). The artist says the park holds a strong sense of Māori and it reflects the tumultuous history of the Te Aro Pā, including the dispossession of land from Māori and the piping of the sacred Waimapihi Stream (Meekings-Stewart, 1992). These artworks demonstrate that there is an interest in the Waimapihi and attempts have been made to reconnect to, and raise awareness of, it as it flows under the city. 


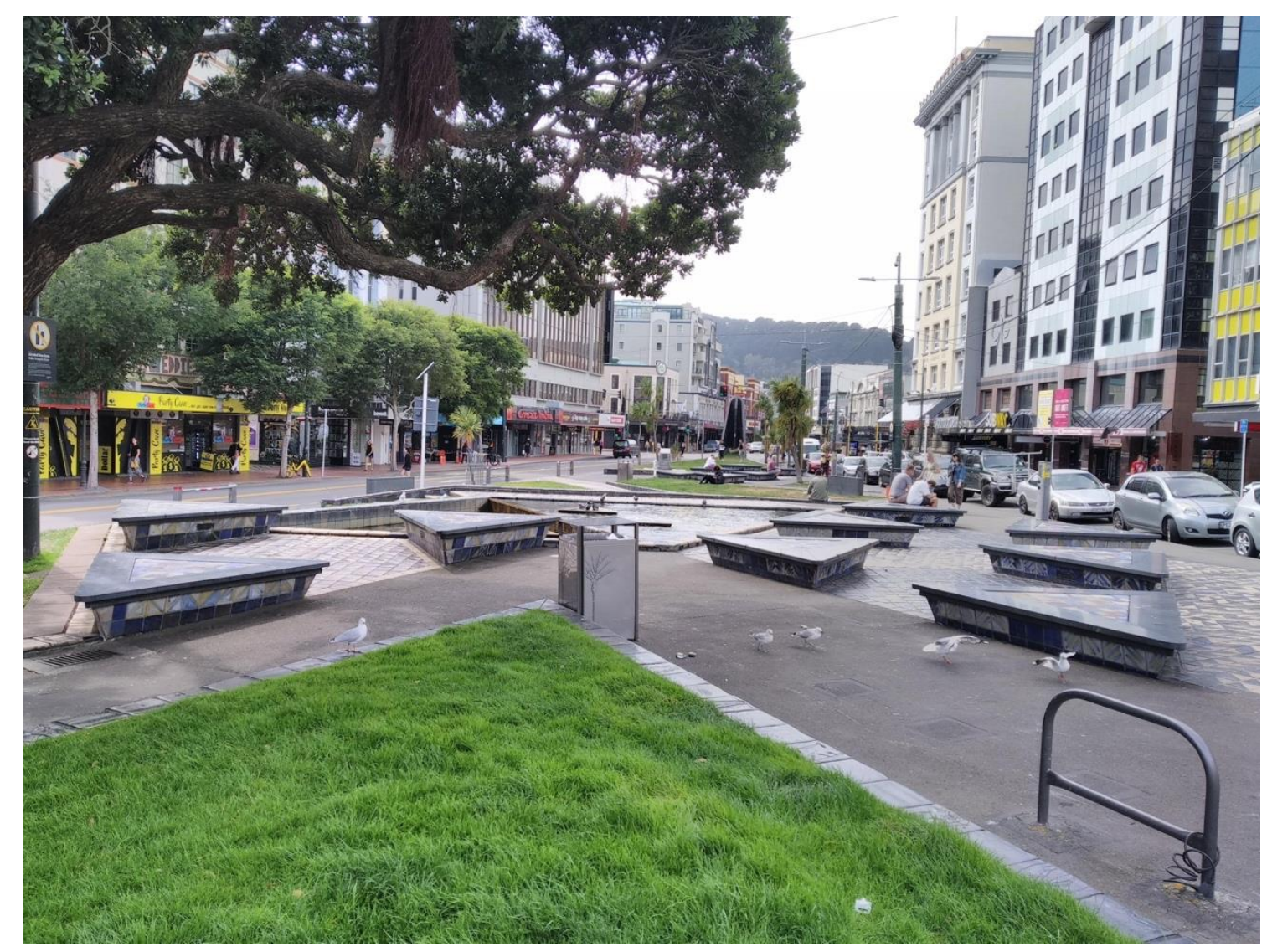

Figure 23: Image of Te Aro Park, looking towards the east.
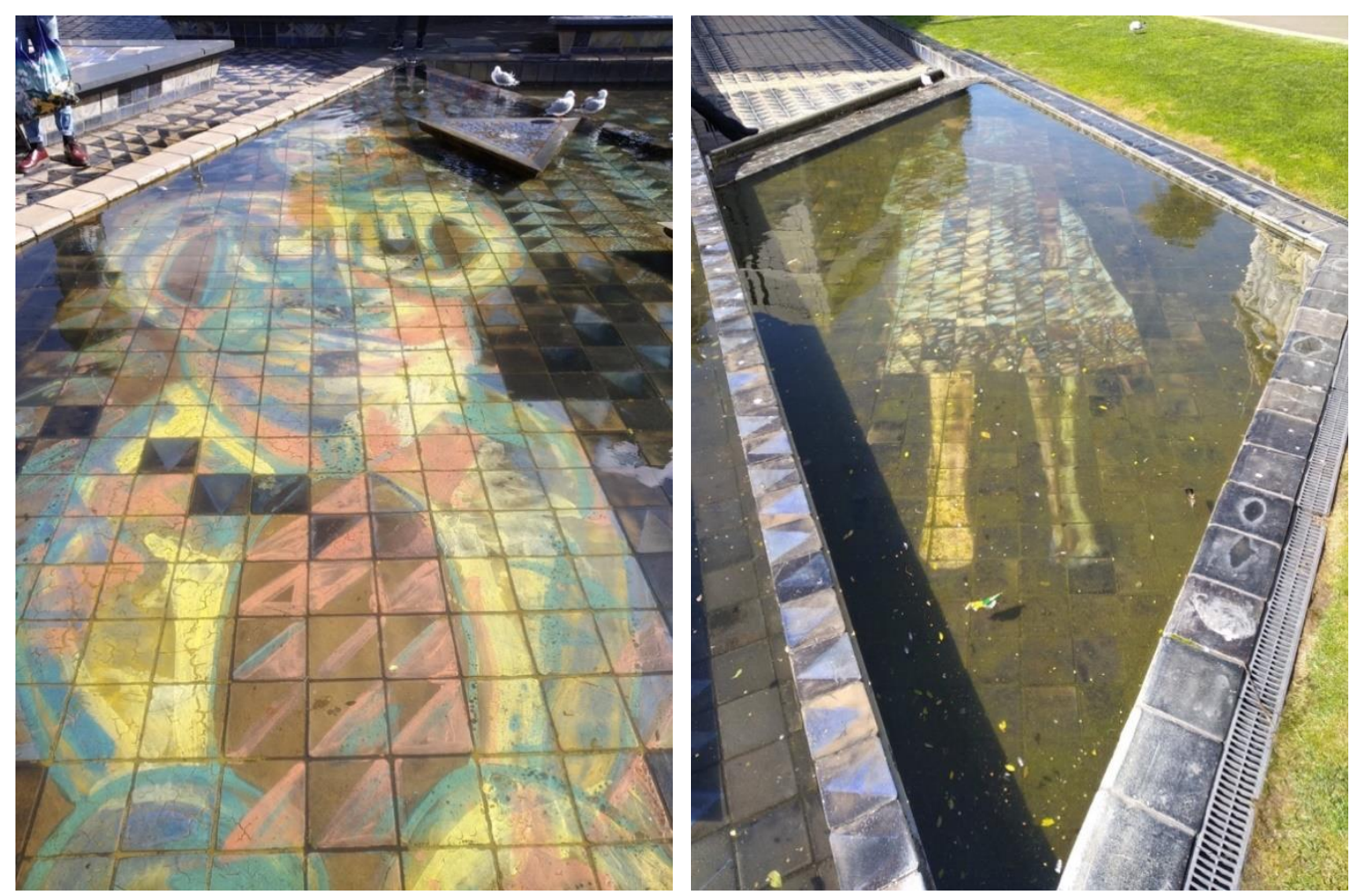

Figure 24: Images of pools at Te Aro Park. 

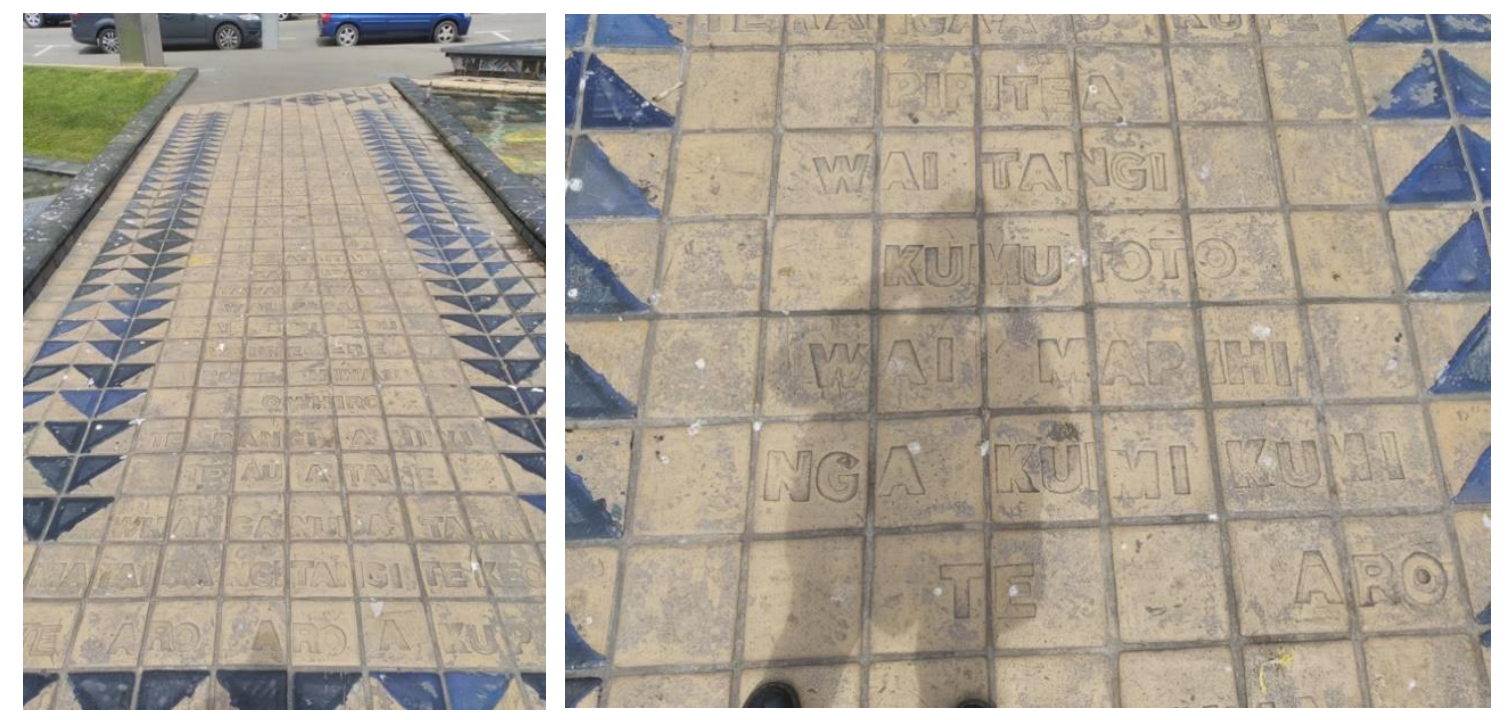

Figure 25: Image of list of streams in Te Whanganui-a-Tara-Wellington on handmade tiles in Te Aro Park, on right the Waimapihi can be seen in the list.

During interviews I showed participants images I had taken of the artworks and asked what they thought of them related to the Waimapihi. In response, many of the participants described how they thought using art was an effective medium to remind people that there was a buried stream underneath them. Sandra said that art was effective as "it's a really visual and easy to, you know everybody can relate to a piece of artwork can't they, in their own way, whatever it means to them" (Interview with Sandra, 23 August 2019). She describes how people can develop their own meanings from interacting with art, that it is a personal experience for how people make connections to the Waimapihi. Sandra, and other participants, highlighted how art being a visual medium makes it more accessible for a range of people, such as children, to interact with. The visual and tangible materiality of the artworks can spark curiosity about what they represent and encourage people to explore the meanings behind the art (Junknickel and Hjorth, 2014). Examining the materiality of the art can expose the more-than-human agency it possesses to influence people's perceptions of the city. Fenske and Norkunas (2017) discussed how exploring the more-than-human agency of our surroundings, such as the art in the city, can encourage people to learn what it means to be just one actor in the world rather than the dominant being in a human-oriented hierarchy. Lily discussed a particular lesson she believes Te Aro Park can teach us about our place in the world, she highlighted how small things like having slippery tiles at Te Aro Park reminds us that we cannot control the world around us and that our attempts to do so are futile. She said that there was a beauty 
in this art that reminds us of our place in the world, as small parts of something larger. She highlights that the art has ways of testing what really matters to us in the city.

I've seen lots of people slip over on it because it holds the water and it's really slippery, those tiles. And now I just think 'haha' because I just think you know, that's so interesting how again it's that thing that water is this inconvenience. And you know, you would never look at the tiles being covered in water and think that is beautiful and there's the water. And at least it's not concrete where it just rushes of, instead it pools in the little crevices between the tiles, and just because she [the artist] hand crafted them all so there's little dips, and dimples, and stuff. And you just see how the water creeps into that and so like of course they are slippery, and then in our stupid little busy lives it is so inconvenient and so you see how we get ourselves into this mess of hurry, quick, efficient, we do it everyday so if that kind of stuff becomes really annoying. But yeah, it's just interesting how actually what that stands for, and what it represents, is actually incredibly beautiful and we are so lucky to have that in the middle of the city like that. And yeah, I just think that the whole built environment has a funny way of teaching us lessons ... it has a funny way of testing what it is that really matters to us (Interview with Lily, 24 July 2019).

She explored the materiality of the art and the physical characteristics of the tiles that have agency to influence where the water flows and pools (Gillon and Gibbs, 2019). She describes how the materials the tiles are made of interact with water to make them slippery, which disrupts people who try to rush across the park, demonstrating how we do not have control over the processes in the world. The tiles change people's perceptions of water to being an inconvenience or even a hazard, highlighting the agency the art has to mediate our understandings of water (Gibbs, 2014). Therefore, this demonstrates how exploring the materiality of the art and the water, and their interaction, enables examination of the socio-natural interactions occurring at the park and city (Swyndegouw, 1996). Engaging with the materiality of the art and its agency to control water allows for an examination of how water is perceived and its place in the city. Opening up these opportunities for learning can encourage people to consider and explore the processes occurring in the city, and the art can raise the curiosity of people to question 
why it is there and what it is trying to represent (Fenske and Norkunas, 2017). These examples demonstrate how art can be used to reconnect people to the landscape that the city has paved over and can pique people's curiosity around the presence of buried streams in Te Whanganui-a-Tara-Wellington.

In addition to the art that is used as a marker of the stream, some participants mentioned how telling the stories of the history of the stream engages people and makes them imagine what the stream was like before the city was built. Rachel mentioned that "naming is so important with those sort of things, not everything has to come from the iwi but it is always good to have their [mana whenua] story because it makes much, much more sense" (Interview with Rachel, 29 August 2019). The idea of naming came up repeatedly in interviews, whether it was that participants already knew about the name of the stream or they did not, and how this informed what they knew or not about the stream. When I told some participants the story behind the name of the stream, that it is called Waimapihi after Mapihi, a rangatira who bathed in the stream, they gained a greater understanding of and appreciation for the stream, it made more sense. When participants heard this story it really ingrained the idea that the stream had been a significant feature of the land, large enough for someone to bathe in. The participants were able to connect to the human activity of bathing in the stream and they were able to visualise the stream in relation to their own bodies. Lily highlighted this when she said "the story of the woman that it's named after, Mapihi, and that story of how she bathed in it and it washed down. And I totally was like, I had that moment of "that is connected to that"” (Interview with Lily, 24 July 2019). She describes how learning the history of a place helped her understand the characteristics of the stream in the past, and how that influences some of the processes occurring and why the place is like it is now. Myfanwy also discussed how telling the stories about the stream in a variety of ways, to a range of people, is important to spread and build the understanding of the Waimapihi, and other buried streams in Te Whanganui-a-Tara-Wellington.

I think there is still a role in actual verbal storytelling, whether you consider that a form of art, I guess it could be. Well I think we go out there and tell our stories in a variety of different ways ... it could be anything as practical as website information all the way through to every conservation 
week I take groups spotlighting, just as kind of a side thing through different streams, and so telling the stories of the stream and actually taking people out physically as part of that as well, so a bit more of an immersive experience ... I've talked a lot to schools about the ecology and the world in which they live ... The library often holds, kind of, readings and events, and so tying it in that way as well. So yeah, just in as many different ways as possible I guess, telling the stories of the streams and what used to be there and what is there now (Interview with Myfanwy, 2 September 2019).

These participants described how telling these stories builds up a local knowledge of the area, which is of great cultural value. This was echoed by Roberts et al. (1995) who described the whakapapa knowledge system in Te Ao Māori that connects everything through time in genealogical relationships, and they discuss how naming is used to tell stories of the genealogy of an entity. Durie et al. (2017) expanded on this idea, describing how naming of entities tells the history of the place that has been built over time and is inseparable from the entity. While Tipa (2009) discussed the value of place names, and associated histories and stories, that provide a focus for understanding places and people, and the ways they are situated in the world. This demonstrates that any physical markers to the buried Waimapihi cannot be disconnected from the name of the stream and the stories behind it.

When discussing how people connected to the buried stream through markers some of the participants talked about the tikanga around using markers to connect to and engage with the whenua and features, such as the Waimapihi. Durie, et al. (2017, p. 1) described tikanga as "the desirable standards by which correctness, justice, or rightness is maintained" and it informs the practice around the whenua. Ra described the tikanga he practiced when making the Z Energy sculpture saying:

From that river [Waimapihi] I took a mauri stone and we put the stone in the foundation of that carving before we put it in its final place. And I guess it's just going to keep it, it'll keep the sculpture safe for as long as it 
is there. We took some water from the source of the stream and also used that for the blessing (Interview with Ra, 23 July 2019).

$\mathrm{Ra}$ is of Te Atiawa descent and has whānau connections to the Waimapihi which informed his practice during the process of making the sculpture and its installation. Rachel, who is Ngāti Awa Ki Aotea on her mother's side and Te Arawa on her father's side (not mana whenua), talked about how during the entire process of creating Te Aro Park they worked closely with mana whenua. She mentioned the importance of following and respecting the tikanga of mana whenua when she said:

I would like to direct you to the tikanga that is required in terms of linking landmarks to waterways and to land and to the local iwi ... the mandate to determine what constitutes a landmark or an eventmark, because you know like sometimes things happen, don't rest with mum, in terms of all that artwork that follows the stream (Interview with Rachel, 29 August 2019).

She highlighted the requirement of following the lead of the mana whenua when developing markers to connect to the land and water of a place. Furthermore, Lily, who is Ngāpuhi and Ngāti Kahu on father's side (not mana whenua), described how the way people interact with the land in general needs to be based on the tikanga of mana whenua. She discussed how the burial of the stream has disconnected people from the Waimapihi, and impacted upon how mana whenua can undertake and direct tikanga around it.

That's all again how you talk about place, that would be completely different if you engaged on that place on a whole different way of going 'oh this is the Waimapihi Stream and maybe at this place you are not allowed to walk through', I guess there's no tikanga around places anymore (Interview with Lily, 24 July 2019).

Lily suggests there needs to be a re-evaluation of how people interact with the land through which the Waimapihi flows, be that underground or on the surface, which should be directed by mana whenua. She suggests that the way people in general talk about place should change to be more aware of the features that the process of urbanisation has attempted to erase from the city. 
The impacts of urbanisation of the landscape of Te Whanganui-a-Tara-Wellington has informed this desire to create markers to reconnect people to the features, such as the Waimapihi, that have been hidden. However, the effectiveness of these markers in connecting people to the Waimapihi was questioned by some participants. Ben mentioned that he thought the artworks were a "cheap alternative to actually having a streambed around" (Interview with Ben, 19 September 2019). Lily reinforced this when she made the "comparison of that tiny triangle in this big city, and this tiny little brick sculpture in the scale of this whole petrol station, for me, that's like a direct representation of what we value" (Interview with Lily, 24 July 2019). She highlighted how the scale of the art in relation to the size of the stream, and the city, really exemplified how little the Waimapihi is valued, that it is not considered to be an important part of the city. Additionally, the signs that tell people what the art is about are small and inconspicuous (figure 26) meaning that people easily miss them. While, Phill mentioned that the art was a "monument" for the stream and Lily agreed when she described how the "memorialisation" of the stream in art fixes the stream in one place and time, implying it is dead.

That was one project in this one moment in time ... and for me it's like these things should be ongoing, these things should be inbuilt into our lives, otherwise of course they just become memorialised... the artwork, both of them are beautiful, but to me they are just swallowed up by what they are surrounded by, like right next to a petrol station really, and it just becomes... I definitely do think that the whole memorialisation thing is just a cop out, a bit, from a larger decision making point of view, like I think it has just become too easy for people to essentially keep doing or developing what they want and then say 'but look we are going to do a karakia and we're going to chuck some art there' and I'm just like that's just not fair to anyone (Interview with Lily, 24 July 2019).

Lily describes what has become all too common, the practice of developing land and then retrospectively trying to commemorate what has been damaged; leading to a cycle of degradation, renovation, and redesign that epitomises urban environments (Kaushal and Belt, 2012). She highlights that the art is being used as a way for people to say they have 
respected the stream by drawing awareness to it, but that practices around the stream remain the same. The city keeps being maintained and developed with a disregard for the stream. Therefore, this demonstrates that the art cannot be the only way people connect to the stream, that it needs to engender further steps to be taken to improve the health of the Waimapihi, or else it will just become memorialised as a dead stream to be remembered.
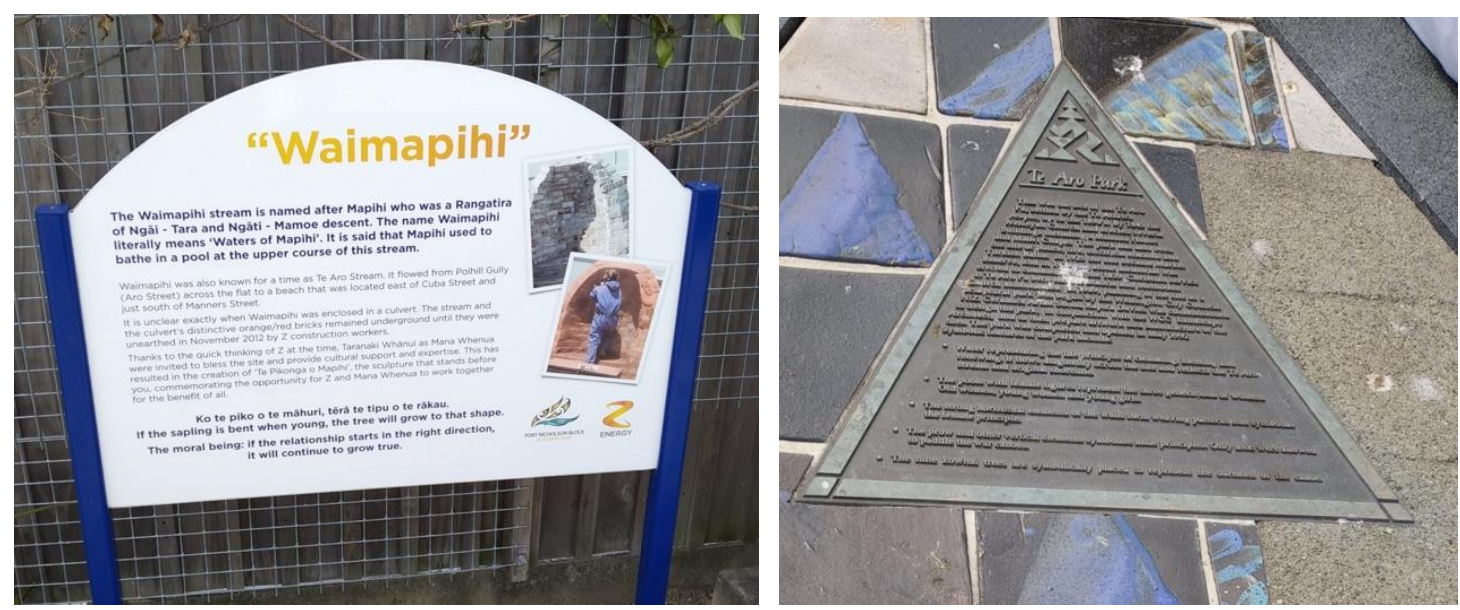

\subsection{Raising Awareness and Engaging with the Waimapihi Stream}

Considering the limitations of the current markers to connect people to the Waimapihi, many of the participants discussed some of the changes they would like to see into the future to raise awareness of and encourage people to engage with the Waimapihi. The participants explored a wide and creative array of options, including signage, naming, art, and windows to the stream, that could be used to draw people's attention to the Waimapihi throughout the city. During the interviews space was made for people to explore these ideas by facilitating a conversation around what people wanted and how the Waimapihi could look different into the future (Blue, 2018). Ian remarked that he thought the stream 
could not be daylighted as it was under the city but that it "can be opened up by information" (Interview with Ian, 22 August 2019). Most of the participants agreed that there needed to be more information about the stream for people to engage with. Sandra said, "definitely better signage and more information regarding the stream, so that more people can understand why and understand our history regarding what was here before all of this" (Interview with Sandra, 23 August 2019). The form that these signs could take and where they could be located was discussed and creative options were suggested by participants. For example, Frances suggested placing signs on gutters in the street that "name the stream that is down there, this is the Waimapihi Stream, home of banded kōkopu. Those signs should be at all those sumps in the gutter" (Interview with Frances, 25 July 2019). She suggested naming the stream and the fish in the pipe to remind people that what happens on the street impacts the life in the buried stream. This idea also was a way to remind people of the various streams throughout the city. Another idea she suggested was:

Maybe we should just do some guerrilla night painting, and just paint it all the way to the Harbour. And it might get eventually painted out and we can just paint it again. And we could put directions saying go around this building to find the continuation of the Waimapihi Stream (Interview with Frances, 25 July 2019).

She suggested this quite radical option as a way to visually remind people of the continuous path of the Waimapihi, that flows underneath their feet, rather than discrete pieces scattered along the path. While Ben suggested the pipe should be renamed to reflect the stream name, “wouldn't it be great to stop calling it Te Aro Culvert and start calling it by its stream name, the asset is not the important thing, the stream is the important thing." (Interview with Ben, 19 September 2019). Making sure the name is used in all aspects of the stream, including policy around pipe management, to remind people that the pipe contains a stream, will be an important step towards showing respect to the Waimapihi. Tipa (2009) describes how place names are used by Māori to reflect the significance and intergenerational relationship between Maori and cultural landscapes, including culturally important waters. The process of naming draws on the history of the stream and naming the pipe after the stream would represent what is important, the Waimapihi Stream. 
There are already pieces of art in the city as physical markers for the stream, but as mentioned previously in the chapter, these are singular pieces that memorialise the stream, implying that it is dead and static, not lively and flowing. Most participants thought it would be more effective and respectful to have continuous work to connect people throughout the length of the stream. Continuous works would better represent the flow of the stream, as a fluid entity, rather than singular pieces (Gibbs, 2014). Rachel suggested the use of traditional Māori pou to represent the path of the stream.

You know how they have all of the high tide marks, if they did that with the stream. And then what you do ... is you put in a pou, and on the pou you have a story. And it doesn't have to be right way in the past, it could be someone who is famous who lived here or wrote something special in this place or something, and then in that way we are actually honouring its passing, I think that's probably really important. (Interview with Rachel, 29 August 2019).

Rachel described an option that could incorporate art and storytelling along the length of the Waimapihi, that could explore the pre-colonial and contemporary history of the city and the stream. She described how understanding the stories of the history of a place makes it more important to people. Phill described another option for continuous work, an idea of incorporating art, visual reality, and stories following the path of the stream.

So in terms of the Waimapihi I would love if there were some continuous or coherent artwork and using virtual reality and things. So that people can know where all our urban streams are under their feet and how that can connect them to the history of the place as well. Cause it is pretty simple to imagine how with VR you could find a signpost that has a QR code that brings up a little virtual reality about the historic houses and the wetland in Dixon Street and lived stories, but the way to geotag them and to have a journey map should be the stream, it can be the thing that holds local stories together, it is the cultural landscape. The fact that Waimapihi is named after Mapihi, we should have that story promoted, and that story should at least be promoted around Aro Park as a cultural community hub, 
and that brings room for Te Atiawa and Taranaki Whānui to come back into that story of the streams as well. So tangata whenua, their history and geography is promoted through that too. And I think streams are fantastic pathways for the kind of journey, that you are holding the story together. I think we can discover other sides to their city (Interview with Phill, 2 August 2019)

He discussed how we only know one side of the city, the one which is presented to us and we interact with, but there are other sides to the city that are hidden from our immediate view, but which are just as important. Both participants described ideas that combine art and storytelling to explore the history of the Waimapihi. These ideas would also likely require asking people to share their stories of the Waimapihi, to accumulate stories to be used in these continuous artworks. This demonstrates the power of artworks and stories to develop local knowledge and foster sharing of it to encourage city residents to be more aware of the impacts of urbanisation on the land and the history of the development of the city.

Many of the participants said that they wanted to be able to see the stream, which art cannot facilitate. They suggested that if daylighting wasn't possible then making windows in the footpath down to the stream, so that it could be seen, could be an option. Phill described Aro Park as a location to have a window:

Even if you couldn't resurface the stream wouldn't it be cool to, if you just took a section of footpath or park where it crosses over the park and install a Perspex or glass footpath for a section, just as long as we can see it (Interview with Phill, 2 August 2019).

Doing this on or near the footpath was an important choice, as there would be thoroughfare and people would be able to look down as they walk and see the stream, and maybe even some fish. Myfanwy also mentioned the idea of a window, but suggested it be located in the central city where there is very little evidence of stream at all, so awareness of its existence needs to be raised: 
I would like to see the people, yeah just aware I guess of what is under their feet, and so even if the Waimapihi is only a small stream, take the awareness across the rest of the city as well. So yeah, ideal, ideal there would be bits of stream or even kind of clear perspex so you could actually see the water running or hear it or some sort of connection (Interview with Myfanwy, 2 September 2019).

She also mentioned an audio connection to the stream, such as having the sound of flowing water being able to be heard. There is an example of this on Aro Street, near Aro Park there is a stormwater grate open so that the Waimapihi Stream could be heard; this could be an option in other places along the stream too. Bringing the Waimapihi back into public consciousness by connecting to people's senses, especially sight and sound, are important for raising awareness of the buried stream (Kaïka and Swyngedouw, 2000). A window to the stream was also suggested by Rachel, as a way to provide a bit of justification for spending money on the stream, that currently many residents don't know is there because they can't see it. She said:

I think that with the stream, because the thing is no way of seeing what is happening in those pipes, as a public they are going to fail to see why the council should spend any money whatsoever on it. So you know maybe instead of bringing the whole stream back to the surface, maybe they can create windows (Interview with Rachel, 29 August 2019).

While, Lily suggested that rather than spending the money on the pieces of art that memorialise the "dead" stream, instead the money should be spent on creating a window to show people the lively stream.

If you're going to commission a memorialisation of it, can you daylight it there, can you give us a glass, where we can see it, or can you give us, so I just feel like if you're going to go to all the effort of saying 'hey there's a stream under here' but I'm like well just show us the stream cause that will essentially do the same thing (Interview with Lily, 24 July 2019).

She demonstrates that some people don't actually want art, they want to see the actual stream, that there is a visceral feeling people get when they see the stream which has more power than when they see art, that they cannot necessarily understand. The idea of 
creating windows was brought up by most participants as an alternative option to daylighting the Waimapihi, if that is not feasible, but one that would still allow people to see the stream.

The above examples highlight the creativity that could be drawn out of people when there is space to talk about what they want for the future of the Waimapihi Stream. They discussed a range of ways to encourage people to reconnect to the stream in the future, including continuous art and stories and a window to the stream. This really illustrates my last point, that there needs to be an opening up of the conversation about the future of the stream to all people, so that creative solutions and opportunities could be explored for how the Waimapihi will look into the future (Gibbs, 2014). Moran (2007) discussed how starting the conversation draws attention to the issues and opens up the process of brainstorming to identify creative alternatives for urban streams into the future. This space for discussion is currently limited and this was articulated by Lily who described that she feels there is stagnation when discussing these issues and that people, particularly those at the councils, are stuck following the status quo. She said, "but what scares me is that we seem to have gotten to this point, that this reality is so fixed and so unchangeable that we can't even open up the dialogue to ask that question" (Interview with Lily, 24 July 2019). This was echoed by Yates, et al. (2017) who discussed the need to change the language around perceptions of water as an important step towards exploring an alternative future. Lily highlighted that we need to think of what we want the future to be like and not consider the challenges initially, or we will never go beyond the status quo. Lily suggested that approaching the issue from a Te Ao Māori perspective would be a fruitful way to start changing the discussion around the Waimapihi.

I feel like it's again that whole I don't see an immediate change in the physical form or the spatial form, but first I see a change in culture around water. And actually, and maybe it's walking backwards into the future, because like from a Te Ao Māori perspective, they've known how to do that for centuries, and how to properly respect and talk about water. And that would never be the case ... that you'd say here's a part of the stream that's important, here's not, like it is, it's all connected. And so in that sense ... we don't have to think about something new, we just have to get 
better at taking something old, and rethinking what it means in the future you know (Interview with Lily, 24 July 2019).

She describes how we don't need to invent something new, we need to consider how those before us have interacted with the Waimapihi and figure out how that interacts with the current situation. She highlighted how essential it is to consider the past of a place when thinking about its future, and suggested that we have to get better at rethinking old understandings of places and how they will inform what the future of the place will become.

\subsection{Conclusion}

The burial of the Waimapihi Stream, over a century ago, has disconnected people from it and changed the way people can interact with it. The hydrosocial approach taken has explored how this burial has had impacts on the identity of local iwi, the community, and the city, and has reconfigured how people perceive water and the place it has in the city. This approach has encouraged exploration of how the infrastructure of the pipe has influenced how people interact with and understand the stream. The piping of the Waimapihi has led to people trying to find new ways to connect to it, such as the three pieces of art along the piped path. The more-than-human approach taken encouraged an examination of the markers along the piped section of the Waimapihi and how these structures have influenced the way some people interact with the stream and how they have made the Waimapihi more accessible and culturally, and socially, significant than before their instalment. However, a hydrosocial approach calls for examination of changes over time, and this illustrates that culturally significant sites were buried when the stream was buried and that pieces of art are not enough to reinstate these culturally important places.

The ability of discrete artworks along the piped path, that memorialise the stream, to reconnect people to the living, flowing entity that is the Waimapihi is limited. These 
works represent the first steps to develop connection but their effectiveness to engage the wider public to interact with the Waimapihi Stream is restricted. Therefore, more must be done to raise awareness of the buried Waimapihi, in particular it was discussed that continuous artworks along the pipe would be more effective than the discrete pieces to reflect the life and fluidity of the Waimapihi. However, more than that, being able to see the stream was important to participants and the idea of open windows to the buried Waimapihi were seen as a potential option to raise awareness of the stream and the fish life within it. With a buried urban stream there needs to be ways for people to connect with it for any change to occur in practices around it or for it to be looked after (Wild, et al., 2017). There needs to be public buy-in and engagement with the process for it to take place and be a success (Moran, 2007). This chapter has demonstrated that people want to engage with the Waimapihi Stream and that it is considered to have an important place in Te Whanganui-a-Tara-Wellington. There was general agreement that the city should not obscure the form of the land and that the city should work with the form, the streams and the city should coexist. Water is a part of the identity of people in Aotearoa-New Zealand and this must include urban streams. 


\section{Chapter Seven: Conclusion}

\subsection{Introduction}

The Waimapihi Stream is spatially and temporally diverse, changing form along its length and through time, and consequently current technocratic methods of management are inadequate for urban streams. Before colonisation, the beginning of urban development of Te Whanganui-a-Tara-Wellington, and the 1855 earthquake, the Waimapihi was a substantial open flowing stream that was a sacred waterway to the many iwi that interacted with it. Fast-forward to the current day and the Waimapihi has a small open section, with the rest of its length buried under the city as it flows out to the Harbour. The temporal and spatial heterogeneity of the stream influences the range of meanings and values people hold about it. This thesis has demonstrated how the hydrosocial cycle is a valuable framework for examining inherently complex urban streams, such as the Waimapihi, as it encourages exploration of the various components of a stream and how these change over time and space. This framework is flexible, thus enabling it to be used to explore a diverse range of urban streams. The hydrosocial cycle encourages critical examination of the meanings people ascribe to water and waterways, and encourages aspirational thinking about the way water and waterways should be understood, valued, and treated into the future (Palomino-Schalscha, et al., 2016).

The research question was: Using the case study of the Waimapihi Stream, how can the hydrosocial cycle be used to explore the meanings of urban streams and how they are valued? The answer to this question, discussed in this thesis, is that it provided a framework to explore the many intersecting aspects of the Waimapihi, including: the phases of the stream, policy around the stream, the fish in the pipe, and people's connections to the stream. The meanings people held around the Waimapihi changed along its length, with ideas of happiness around the headwaters but despair at the piped section of the stream under the city, that is polluted and flows in a leaky pipe. This anger and sadness about the polluted, leaky pipe increased during discussions about the fish in 
the pipe and how they navigate dirty stormwater. The presence of fish was greeted with general surprise and excitement and made people value the piped section more, saying it was a 'living' stream. The meanings and values people ascribed to the Waimapihi were not hard and fast between the piped and open section, with many different perceptions held within the two sections. They were also not static, changing through time as people interacted with the stream. Perceptions of the pipe for the future were imbued with some hope around daylighting and a whole range of creative ideas about how to connect to the stream and raise awareness of and engage with the piped section of the Waimapihi. This hope was not continuous however, and there was a resignation about the inevitability of some of the stream remaining piped permanently due to its location under the city. This broad range of aspects could be explored because the scope of investigation encompassed: the physical water flow; the social structure, power, and institutions; and the infrastructure and technology. Therefore, the hydrosocial cycle enables the complexity of a buried urban stream to be explored. It aims to question how freshwater could and should be and recognises that the current dominant understanding is just one of many (Linton and Budds, 2014).

The remainder of this section will summarise the central points of discussion and some of the limitations of this research. It will then outline the implication of these points on hydrosocial theory and policy around buried streams and urban freshwater, and the opportunities for further research. Some final thoughts will bring the thesis to an end.

\subsection{Thesis Summary}

Chapter Four began by delving into ideas around urbanisation and the control of water by examining the relationship between waterways and urban development, and how they shape each other, forming city structures and degrading urban waterways. This led to the exploration of the spatial and temporal phases of the Waimapihi Stream. The first phase was the open section in the Waimapihi Reserve, which demonstrated some of the aspects of the past of the stream and the city, and how much the rest of the stream has been modified. The second phase analysed was the Waimapihi as stormwater, reflecting its 
current state, flowing through pipes mixed with "dirty" stormwater and so becoming stormwater. The final phase of the Waimapihi was the potential (hopeful) future daylighting of the Waimapihi, or sections of it wherever possible, to reconnect people to the stream and improve habitat and biodiversity. Chapter Four finished with an investigation into the influence of the RMA (1991) and other policy on the various phases of the Waimapihi, and the power relations occurring along the stream between and within local government. This chapter answered the research question by examining the Waimapihi Stream, and its various phases, and providing an example of using the hydrosocial cycle to examine the complex interrelationships between water flow, the pipe, and social power and institutions that produce the waters of the Waimapihi. This approach facilitated an investigation of how a stream is defined and understood by the public and within law, policy, and management, and how this is fluid through space and time so cannot be separated into discrete sections. This demonstrated that the hydrosocial cycle provides a good framework to explore the complexity inherent in urban streams.

Chapter Five explored the presence of fish in the Waimapihi Stream, beginning with exploring the fish and their habitat in the open headwaters in the Waimapihi Reserve. The movement of fish through the piped phase of the Waimapihi was then investigated, examining the influence of the pipe on water flow and quality, fish movement, lifecycle behaviours, and survival. This exploration of the influence of the pipe on fish movement led to the idea of the presence of fish bringing life to the pipe and informing people's understanding of the water in the pipe as a stream habitat. The final section of Chapter Five outlined processes that could be undertaken to enhance the passage of fish through the piped section to the headwaters. This chapter aimed to examine the Waimapihi Stream from the perspective of fish to reorient the research from an entirely human perspective. This chapter answered the research question as it demonstrated how using a hydrosocial approach encourages exploration of a range of meanings and values attributed to the stream, including those of more-than-human entities such as fish. A hydrosocial cycle approach alongside a more-than-human methodology enabled exploration of the social component that makes up the Waimapihi, and this social component included the nonhuman social: the fish life in the stream. 
Chapter Six explored people's connection to the Waimapihi Stream, opening with an examination of how the burial of the stream has disconnected it from the public by removing it from view and out of their consciousness, reinforcing the idea of streams being only open flowing entities. The next section explored the alternative ways people have tried to connect to the Waimapihi now that it flows through a pipe underground, such as storytelling and the three pieces of art along the piped path. This led to an investigation of the effectiveness of markers to connect people to a buried stream, whether they teach lessons about the landscape hidden under the city, or if they only act as a monument that memorialised the stream, fixing it in space and time, and implying that it is dead. The final section of Chapter Six explored options to raise awareness of, and engage with, the stream into the future, including continuous art, windows down into the stream, and widespread storytelling and sharing. Chapter Six answered the research question as it illustrated how using a hydrosocial approach opens up exploration of a range of meanings and values of the Waimapihi Stream. This chapter explored how people currently value the Waimapihi Stream and how they wish to reconnect to it into the future with a range of methods.

\subsection{Limitations of this Research}

A significant limitation to this research was that no mana whenua from the area were interviewed through formal channels about the Waimapihi. This is significant because mana whenua possess particular knowledge about and understandings of the Waimapihi, and as mana whenua, they also have particular kaitiakitanga relationships with the stream. I did attempt to make contact with mana whenua, but this request was one of many as iwi and hapū groups across the country face huge demands on their time (Morning Report, 2020). In addition, my ability to develop strong, trusting relationships with these groups was limited by my, and my supervisors, currently shallow connections with them and the time constraints of completing a Masters thesis (in a western institution that is driven by a different set of priorities). 
Another limitation was that my messy methods were constrained by the scope of a Masters thesis. The only method used to explore more-than-human meanings was fish spotlighting, but fish are only one way of exploring more-than-human values in the stream. Ideally, more tools would have been used to engage with many more-thanhumans. These methods might have included macroinvertebrate measurements, bird counting, transect or quadrat sampling of plants, soil surveys, water quality sampling, or structural surveys of the pipe. There are so many more-than-human entities in the stream that could be explored, and this research only began to investigate them.

\subsection{Implications and Further Research}

The hydrosocial cycle incorporates the physical flow of water, the social and power relations, and the infrastructure that make up water (Linton and Budds, 2014). Incorporating these components is what makes the hydrosocial cycle such a valuable framework for examining urban streams. This thesis used the Waimapihi Stream as a case study to explore how a hydrosocial approach could improve how urban streams are studied and understood. The implication of this research is that it presents an example of the nuance and complexity that can be discovered about an urban stream using the hydrosocial cycle. It has shown that urban streams are not uniform but have many different phases, some more modified than others, through which the stream flows continuously. The hydrosocial approach informed my examination of the materiality of these phases of the stream, how they have been perceived, and how they have changed through space and time. It has shown that meanings and values around the Waimapihi and its phases are complex and fluid, and that there are many ways people understand the stream and its place in the city, which have changed through time and space.

Another implication of this research has been to explore what we conceive a stream to be, and show that we cannot have one definition because there is huge variety between rural and urban streams, amongst urban streams, and even within a single urban stream. Examining what we measure, how we name things and why, and the political context this 
is done within is an important step to opening up our understandings of environmental management (Blue and Brierley, 2016). This does not mean reject all knowledge, perspectives, and approaches that have been established on good evidence from research (Blue and Brierley, 2016). There is value in technocratic management practices that are easily measurable, but they are insufficient alone to explore the diverse ways waterways can be and how different people perceive freshwater between different places and times (Blue, 2018). Therefore, a flexible framework such as the hydrosocial cycle to explore all the interacting components that makeup a waterway is a much more effective method for understanding the characteristics and state of urban streams. However, it should not be forced to be an operational tool that allows you to quantify a waterway. It must retain its flexibility to be a guiding framework to focus research and management for place-specific aspirational visions of what urban streams could become (Blue, 2018).

Using the hydrosocial cycle to reconfigure what we understand streams to be could have implications for freshwater policy. Primarily, it could influence the acknowledgement of buried streams to be streams under the RMA (1991), as the cycle recognises the diversity of streams and that they all need to have the legal protections we place on open streams. It could also inform protections towards fish in buried urban streams as it acknowledges that the life in a stream makes up that stream and so must be protected. It may also contribute to more effective enactment of the NPS-FM (2014), that calls for the holistic and integrated wellbeing of a waterway to be maintained. Under the hydrosocial cycle this encapsulates the wellbeing of water, plants, animals, infrastructure, and people. The harmony of these hydrosocial components of the Waimapihi is vital for improved wellbeing of urban freshwater that is stipulated under the NPS-FM (2014).

There are opportunities for future freshwater management to consider how more inclusive forums for decision-making might be created. These forums should include knowledge sharing opportunities that incorporate the voices of a wider range of people including residents, mana whenua, children, and many more, alongside those of freshwater scientists, engineers, and policy analysts. This inclusion would encourage acknowledgement of the fundamental importance of cultural identity and the multiplicity 
of knowledge systems and perspectives about waterways in freshwater management (Brierley, et al., 2018). Exploring other peoples' understandings of water will improve water governance, as incorporating perspectives from all groups in society results in a greater understanding of water and the people interacting with it, and greater participation in water governance (Tipa, 2009). Diversity of who is involved in freshwater policy and management will expand how streams are understood and treated. This must go further than current "participation" that is tokenistic and limited, to allow residents to take ownership of their locality and reconnect with the landscape which the process of urbanisation has hidden. Exploring what went into making Te Whanganui-a-TaraWellington what it is today (and what has been lost) allows people to appreciate the city and understand why certain events like the Harbour being unsafe for swimming occur. Understanding these processes will encourage changes to be made to how water in the city is valued and used. This will require changing how the councils engage communities and understand, and undertake, community participation.

This thesis answered the research question; however, the question was intentionally broad to demonstrate that there is still a lot to learn from using the hydrosocial cycle and studying urban streams. Therefore, answering the research question raised many more questions for further study into the future, such as: what is a stream legally under various laws and policies in Aotearoa-New Zealand and do these align, and if not, how can this be remedied? What are the logistics of creating windows to the Waimapihi and other urban streams? What are the best fish passage enhancement methods for buried streams, and how, where, and at what cost can they be installed? What are the logistics for daylighting buried urban streams in Te Whanganui-a-Tara-Wellington? How many wastewater cross-connections are there into the Waimapihi pipe or adjacent pipes, and when and how will this be fixed? Is there a way to disconnect the Waimapihi from the stormwater network so that it is not mixed with stormwater? These are just some of the questions that undertaking this research has led me to consider. They offer some directions for further research around the Waimapihi and other buried urban streams in Te Whanganui-a-Tara-Wellington. The hydrosocial cycle allows exploration of aspects and issues that would normally be forgotten using technocratic methods and allows examination of nuance and complexity, so it provides a good first step to catalyse further 
research. There is a dearth of knowledge around the buried urban streams of Te Whanganui-a-Tara-Wellington, and Aotearoa-New Zealand generally, so this would be a good place to begin for further research. Carrying this research out under a variety of disciplines, such as ecology, hydrology, anthropology, history, resource management, law, and engineering would be beneficial to build a broad array of knowledge around urban streams.

The hydrosocial cycle has not been applied often to urban streams, so further work is required to explore how the hydrosocial cycle can be used to investigate the range of complexity of different urban streams. The interactions between water flow, infrastructure, and social structures and institutions changes in every different context, therefore, it is important to study the hydrosocial cycle in a range of contexts. For example, it could be beneficial to explore the use of the hydrosocial cycle to study different streams in Te Whanganui-a-Tara-Wellington that have less or more of their length buried, such as the Kumutoto or Kaiwharawhara, to examine the hydrosocial relations occurring. Furthermore, it could be valuable to explore the use of the hydrosocial cycle for examining urban streams while incorporating a wider range of more-thanhuman perspectives. This will build up a catalogue of examples of studies using the hydrosocial cycle and of urban streams in a variety of settings.

\subsection{Final Thoughts}

This research has demonstrated that a waterway is more than just it's flow of water: it comprises the infrastructure it flows through and the social interactions and power relations occurring within and around it; which is the thinking that arises from using a hydrosocial cycle approach to exploring a waterway. Taking a hydrosocial approach has shown that it is essential to explore the past of a place to have any understanding of its present and future. This research used the Waimapihi Stream as an example of how the hydrosocial cycle can be used to explore the meanings and values held around it, and to question the assumptions held around buried urban streams in Te Whanganui-a-TaraWellington, Aotearoa-New Zealand. This work will hopefully encourage people to perceive waterways in Aotearoa-New Zealand more critically and holistically, to 
appreciate that the status quo is not working, and that how we engage with and understand buried urban streams must change. When conversations were initiated to explore an alternative future for the Waimapihi there was creativity and hope, despite the sadness and resentment, which demonstrated that people can imagine the stream differently. People did care about the buried streams, including the Waimapihi, which is the first step towards a future where they are treated with more respect and become a prominent part of Te Whanganui-a-Tara-Wellington.

These streams are the lifeblood of the city. They are focal points for biodiversity, and social and cultural value and understandings, and must be respected and cared for. For this to be achieved there needs to be a broadening of understandings of the past and present realities of streams so that the public might critically engage - with councils and led by mana whenua - about plans for their futures. Critical engagement requires that the public is aware of buried urban streams, meaning they need to become more acknowledged and accessible so people can interact and build relationships with them into the future. 


\section{References:}

Allon, F. and Sofoulis, Z. (2006). Everyday Water: cultures in transition. Australian Geographer, 37(1), 45-55. doi.org/10.1080/00049180500511962

Amtstaetter, F., O’Connor, J., Borg, D., Stuart, I., and Moloney, P. (2017). Remediation of upstream passage for migrating Galaxias (Family: Galaxiidae) through a pipe culvert. Fisheries Management and Ecology, 24(3), 186-192. doi.org/10.1111/fme.12211

Appleton, N. S. (2019, February 04). Do Not 'Decolonize' ... If You Are Not Decolonizing: Progressive Language and Planning Beyond a Hollow Academic Rebranding. [Web log post]. Critical Ethnic Studies, University of Minnesota Press. Retrieved from http://www.criticalethnicstudiesjournal.org/blog/2019/1/21/do-not-decolonizeif-you-are-not-decolonizing-alternate-language-to-navigate-desires-forprogressive-academia-6y5sg\#_ftnref1

Aro Valley Preschool (n.d.). Preschool Mosaic Mural Project. [Web log post]. Aro Valley Preschool: News Archive. Retrieved from https://www.arovalleypreschool.nz/p/preschool-mosaicmural-project-over.html

Bakker, K. J. (2003). A Political Ecology of Water Privitization. Studies in Political Economy, 70(1), 35-58. doi.org/10.1080/07078552.2003.11827129 
Bakker, K. J. (2012). Water: Political, biopolitical and material. Social Studies of Science, 42, 616-623. doi:10.1177/0306312712441396

Ballance, A. (2019, May 30). The streams beneath the streets. Radio New Zealand. Retrieved from https://www.rnz.co.nz/national/programmes/ourchangingworld/audio/20186972 87/the-streams-beneath-the-streets

Bear, C. and Eden, S. (2011). Thinking like a fish? Engaging with nonhuman difference through recreation angling. Environment and Planning D: Society and Space, 29(2), 336-352. doi.org/10.1068/d1810

Blue, B. (2018). What's wrong with healthy rivers? Promise and practice in the search for a guiding ideal for freshwater management. Progress in Physical Geography, 42(4), 462-477. doi.org/10.1177/0309133318783148

Blue, B. and Brierley, G. (2016). 'But what do you measure?' Prospects for a constructive critical physical geography. Area, 48(2), 190-197. https://doi.org/10.1111/area.12249

Boubée, J., Jowett, I., Nichols, S., and Williams, E. (1999). Fish Passage in Culverts: A review, with possible solutions for New Zealand Indigenous species. Te Whanganui-a-Tara-Wellington, Aotearoa-New Zealand: Department of Conservation and National Institute of Water and Atmospheric Research. Retrieved from https://www.doc.govt.nz/globalassets/documents/science-andtechnical/culverts01.pdf 
Brassell, J. (2014). Polhill Reserve History. Wellington City Council. Retrieved from https://wellington.govt.nz/recreation/enjoy-the-outdoors/parks-andreserves/town-belt-reserves/george-denton-park-and-polhill-reserve/polhillreserve-history

Braun, V., and Clark, V. (2006). Using thematic analysis in psychology. Qualitative Research in Psychology, 3(2), 77-101. doi.org/10.1191/1478088706qp063oa

Brierley, G., Tadaki, M., Hikuroa, D., Blue, B., Šunde, C., Tunnicliffe, J., and Salmond, A. (2018). A geomorphic perspective on the rights of the river in Aotearoa New Zealand. River Research and Applications, 35(10), 1640-1651. https://doi.org/10.1002/rra.3343

Buller, H. (2015). Animal geographies II: Methods. Progress in Human Geography, 39(3), 374-384. https://doi.org/10.1177/0309132514527401

Chakravarthy, K., Charters, F., and Cochrane, T. A. (2019). The Impact of Urbanisation on New Zealand Freshwater Quality. Policy Quarterly, 15(3), 17-21. https://doi.org/10.26686/pq.v15i3.5683

Costantino, T. E. (2008). Constructivism. In L. Given (Eds.), The SAGE Encyclopedia of Qualitative Research Methods (Vol. 1-2, pp. 116-120). Thousand Oaks, CA: SAGE Reference Publications.

Cousins, J. J. (2017a). Structuring Hydrosocial Relations in Urban Water Governance. Annals of the American Association of Geographers, 107(5),1144-1161. https://doi.org/10.1080/24694452.2017.1293501 
Cousins, J. J. (2017b). Volume control: Stormwater and the politics of urban metabolism. Geoforum, 85, 368-380. https://doi.org/10.1016/j.geoforum.2016.09.020

David, B. O., Hamer, M. P., and Collier, K. J. (2009). Mussel spat ropes provide passage for banded kōkopu (Galaxias fasciatus) in laboratory trials. New Zealand Journal of Marine and Freshwater Research, 43, 883-888. https://doi.org/10.1080/00288330909510046

David, B. O. and Hamer, M. P. (2012). Remediation of a perched stream culvert with ropes to improve fish passage. Marine and Freshwater Research, 63, 440-449. https://doi.org/10.1071/MF11245

Denzin, N. K. and Lincoln, Y. S. (2008). Introduction: Critical Methodologies and Indigenous Inquiry. In N. K. Denzin, Y. S. Lincoln, and L. T. Smith (Eds.), Handbook of Critical and Indigenous Methodologies (pp. 1-21). Thousand Oaks, CA: SAGE Publications. https://dx.doi.org/10.4135/9781483385686.n1

Department of Internal Affairs. (2017). Review of the waters infrastructure services: Initiating key findings for discussion with the Minister for Local Government. Te Whanganui-a-Tara-Wellington, Aotearoa-New Zealand. Retrieved from https://www.dia.govt.nz/diawebsite.nsf/Files/Three-Waters-Review-Cabinetpapers-April-2018/\$file/Review-of-three-waters-infrastructure-services-keyfindings-November-2017.pdf

Dowling, R., Lloyd, K., and Suchet-Pearson, S. (2017). Qualitative methods II: 'Morethan-human' methodologies and/in praxis. Progress in Human Geography, 41(6), 823-831. https://doi.org/10.1177/0309132516664439 
Dunn, N.R., Allibone, R. M., Closs, G. P., Crow, S. K., David, B. O., Goodman, J. M., Griffiths, M., Jack, D. C., Ling, N., Waters, J. M., and Rolfe, J. R. (2018). New Zealand Threat Classification Series 24: Conservation status of New Zealand freshwater fishes, 2017. Te Whanganui-a-Tara-Wellington, Aotearoa-New Zealand: Department of Conservation. Retrieved from https://www.doc.govt.nz/Documents/science-andtechnical/nztcs24entire.pdf

Durie, E. T., Joseph, R., Eruti, A., Toki, V., Ruru, J., Jones, C., and Hook, G. R. (2017). Ngā Wai O Te Māori, Ngā Tikanga me Ngā Ture Roia, The Waters of the Māori: Mãori Law and State Law. A paper prepared for the New Zealand Māori Council. Waikato, Aotearoa-New Zealand. Retrieved from https://researchcommons.waikato.ac.nz/bitstream/handle/10289/11811/Report\% 20-\%20The\%20Water\%20of\%20the\%20Maori.pdf?sequence $=2 \&$ is Allowed $=y$

Elmore, A. J. and Kaushal, S. S. (2008). Disappearing headwaters: patterns of stream burial due to urbanisation. Frontiers in Ecology and the Environment, 6, 308312. https://doi.org/10.1890/070101

England, K. V. L. (1994). Getting Personal: Reflexivity, Positionality, and Feminist Research. Professional Geographer, 46(1), 80-89. https://doi.org/10.1111/j.0033-0124.1994.00080.x

Fenske, M. and Norkunas, M. (2017). Experiencing the More-Than-Human World. Narrative Culture, 4(2), 105-110. doi: 10.13110/narrcult.4.2.0105 
Fossey, E., Harvey, C., McDermott, F., and Davidson, L. (2002). Understanding and evaluating qualitative research. Australian and New Zealand Journal of Psychiatry, 36, 717-732. https://doi.org/10.1046/j.1440-1614.2002.01100.x

Franklin, P., Gee, E., Baker, C., and Bowie, S. (2018). New Zealand Fish Passage Guidelines For Structures Up To Four Metres. Te Whanganui-a-TaraWellington, Aotearoa-New Zealand: National Institute of Water and Atmospheric Research. Retrieved from https://niwa.co.nz/static/web/freshwaterand-estuaries/NZ-FishPassageGuidelines-upto4m-NIWA-DOC-NZFPAG.pdf

Gandy, M. (2004). Rethinking urban metabolism: Water, space and the modern city. City, 8(3), 363-379. https://doi.org/10.1080/1360481042000313509

Gibbs, L. M. (2009). Water Places: Cultural, Social and More-Than-Human Geographies of Nature. Scottish Geography Journal, 125, 361-369. https://doi.org/10.1080/14702540903364393

Gibbs, L. M. (2014). Freshwater geographies? Place, matter, practice, hope. New Zealand Geographer, 70, 56-60. doi:10.1111/nzg.12040

Gibbs, L. M. (2018). Shores: Sharks, Nets and More-Than-Human Territory in Eastern Australia. In K. Peters, P. Steinberg, and E. Stratford (Eds.), Territory Beyond Terra (pp. 203-219). London, England: Rowman \& Littlefield International.

Gillon, C. and Gibbs, L. M. (2019). Coastal homemaking: Navigating housing ideals, home realities, and more-than-human processes. Environment and Planning D: Society and Space, 37(1),104-121. https://doi.org/10.1177/0263775818811140 
Glaw, X., Inder, K., Kable, A., and Hazelton, M. (2017). Visual Methodologies in Qualitative Research: Autophotography and Photo Elicitation Applied to Mental Health Research. International Journal of Qualitative Methods, 16, 1-8. https://doi.org/10.1177/1609406917748215

Gooch, M. and Rigano, D. (2010). Enhancing Community-scale Social Resilience: what is the connection between healthy communities and healthy waterways? Australian Geographer, 41,4, 507-520. https://doi.org/10.1080/00049182.2010.519698

Grainger, N., Collier, K., Hitchmough, R., Harding, J., Smith, B., and Sutherland, D. (2014). New Zealand Threat Classification Series 8: Conservation status of New Zealand freshwater invertebrates, 2013. Te Whanganui-a-Tara-Wellington, Aotearoa-New Zealand: Department of Conservation. Retrieved from https://www.doc.govt.nz/documents/science-and-technical/nztcs8entire.pdf

Greater Wellington Regional Council (1999). Regional Freshwater Plan for the Wellington Region. Rule 2 Stormwater Discharge. Te Whanganui-a-TaraWellington, Aotearoa-New Zealand. Retrieved from https://www.gw.govt.nz/assets/Plans--Publications/Regional-Freshwater$\underline{\text { Plan/Regional-Freshwater-Plan-updated-July-2014.pdf }}$

Hatt, B. E., Fletcher, T. D., Walsh, C. J., and Taylor, S. L. (2004). The influence of urban density and drainage infrastructure on concentrations and loads of pollutants in small streams. Journal of Environmental Management, 34, 112124. doi: $10.1007 / \mathrm{s} 00267-004-0221-8$ 
Horton, R. E. (1931). The field, scope, and status of the science of hydrology. Eos, Transactions American Geophysical Union, 12(1), 189-202. https://doi.org/10.1029/TR012i001p00189-2

Joy, M., David, B., and Lake, M. (2013). New Zealand Freshwater Fish Sampling Protocols, Part 1 - Wadeable Rivers and Streams. Te Papa-i-Oea-Palmerston North, Aotearoa-New Zealand: The Ecology Group - Institute of Natural Resources Te Kura Matauranga o nga Taonga a Papatūānuku, Massey University. Retrieved from https://niwa.co.nz/static/web/New_Zealand_Freshwater_Fish_Sampling_Protoc ols.pdf

Joy, M. K. and Death, R. G. (2013). Freshwater Biodiversity. In J. Dymond (Eds.), Ecosystem services in New Zealand - conditions and trends (pp. 448-459). Lincoln, Aotearoa-New Zealand: Manaaki Whenua Press.

Jungnickel, K. and Hjorth, L. (2014). Methodological entanglements in the field: methods, transitions and transmissions. Visual Studies, 29(2), 136-145. https://doi.org/10.1080/1472586X.2014.887263

Kaïka, M. and Swyngedouw, E. (2000). Fetishizing the Modern City: The Phantasmagoria of Urban Technological Networks*. International Journal of Urban and Regional Research, 24, 120-138. https://doi.org/10.1111/14682427.00239

Kaushal, S. S. and Belt, K. T. (2012). The urban watershed continuum: evolving spatial and temporal dimensions. Urban Ecosystems, 15, 409-435. DOI $10.1007 / \mathrm{s} 11252-012-0226-7$ 
Kimmerer, R. (2012). Searching for synergy: integrating traditional and scientific ecological knowledge in environmental science education. Journal of Environmental Studies and Science, 2, 317-323. DOI: 10.1007/s13412-0120091-y

Kulka, A. (2000). Defining Constructivism. In A. Kulka (Eds.), Social Constructivism and the Philosophy of Science (pp. 1-7). London, England: Routledge.

Larsen, S. C. and Johnson, J. T. (2016). The Agency of Place: Toward a More-ThanHuman Geographical Self. GeoHumanities, 2(1), 149-166. https://doi.org/10.1080/2373566X.2016.1157003

Linton, J. and Budds, J. (2014). The hydrosocial cycle: Defining and mobilising a relational-dialectic approach to water. Geoforum, 57, 170-180. https://doi.org/10.1016/j.geoforum.2013.10.008

Love, M. (2005, February 8). Te Atti Awa of Wellington. Te Whanganui-a-TaraWellington, Aotearoa-New Zealand: Te Ara - The Encyclopedia of New Zealand. Retrieved from https://teara.govt.nz/en/te-ati-awa-of-wellington

Maclean, C. (2007, July 9) Wellington region - Creation stories and landscape. Te Whanganui-a-Tara-Wellington, Aotearoa-New Zealand: Te Ara - The Encyclopedia of New Zealand. Retrieved from https://teara.govt.nz/en/wellington-region/page-2 
McConchie, J., Winchester, D. R., and Willis, R. (2000). Dynamic Wellington: A contemporary synthesis and explanation of Wellington. Te Whanganui-a-TaraWellington, Aotearoa-New Zealand: Institute of Geography, Victoria University of Wellington.

McEwan, A. J. and Joy, M. K. (2009). Differences in the distributions of freshwater fishes and decapod crustaceans in urban and forested streams in Auckland, New Zealand. New Zealand Journal of Marine and Freshwater Research, 43, 11151120. https://doi.org/10.1080/00288330.2009.9626534

McGettigan, T. (2008). Power. In L. Given (Eds.), The SAGE Encyclopedia of Qualitative Research Methods (Vol. 1-2, pp. 670-671). Thousand Oaks, CA: SAGE Reference Publications.

McGregor, A., Challies, E., Thomas, A., Astuti, R., Howson, P., Afiff, S., Kindon, S., Bond, S. (2019). Sociocarbon cycles: Assembling and governing forest carbon in Indonesia. Geoforum, 99, 32-41. https://doi.org/10.1016/j.geoforum.2018.12.003

Mitchell, C. P. (1989). Swimming performances of some native freshwater fishes. New Zealand Journal of Marine and Freshwater Research, 23(2), 181-187. https://doi.org/10.1080/00288330.1989.9516354

Meekings-Stewart, P. (Producer and Director). (1992). A cat among the pigeons [Television broadcast]. Aotearoa-New Zealand: NZ on Screen. 
Moran, S. (2007). Stream Restoration Projects: A Critical Analysis of Urban Greening. Local Environment. The International Journal of Justice and Sustainability, 12(2), 111-128. https://doi.org/10.1080/13549830601133151

Morning Report (2020, February 21). Wellington mana whenua say they're stretched to capacity over water. Radio New Zealand. Retrieved from https://www.rnz.co.nz/national/programmes/morningreport/audio/2018735135/ wellington-mana-whenua-say-they-re-stretched-to-capacity-over-water

Napieralski, J. A. and Welsh, E. S. (2016). A century of stream burial in Michigan (USA) cities. Journal of Maps, 12(1), 300-303. https://doi.org/10.1080/17445647.2016.1206040

Neale, M. W. and Moffett, E. R. (2016). Re-engineering buried urban streams: Daylighting results in rapid changes in stream invertebrate communities. Ecological Engineering, 87, 175-184. https://doi.org/10.1016/j.ecoleng.2015.11.043

National Library of New Zealand (1853, March 5). New Zealand Spectator and Cook's Strait Guardian. Retrieved from https://paperspast.natlib.govt.nz/newspapers/NZSCSG18530305.2.3?query=Te \%20Aro\%20Stream\&page $=5 \&$ start_date $=1844-01-01 \&$ end date $=1865-01$ $\underline{01 \& \text { title }=\mathrm{NZSCSG}}$

Nicholls, R. (2009). Research and Indigenous participation: critical reflexive methods. International Journal of Social Research Methodology, 12(2), 117-126. https://doi.org/10.1080/13645570902727698 
Palomino-Schalscha, M., Leaman-Constanzo, C., and Bond, S. (2016). Contested water, contested development: unpacking the hydrosocial cycle of the Nuble River, Chile. Third World Quarterly, 37(5), 883-901. https://doi.org/10.1080/01436597.2015.1109436

Panelli, R. (2010). More-than-human social geographies: posthuman and other possibilities. Progress in Human Geography, 34(1), 79-87. https://doi.org/10.1177/0309132509105007

Paul, M.J., Meyer, J.L. (2008). Streams in the Urban Landscape. In J. M. Marzluff, E. Shulenberger, W. Endlicher, M. Alberti, G. Bradley, C. Ryan, U. Simon, and C. ZumBrunnen (eds) Urban Ecology: An International Perspective on the Interaction Between Humans and Nature (pp. 207-231). Boston, MA, USA: Springer.

Poe, M. R., Donatuto, J., and Satterfield. T. (2016). "Sense of Place”: Human Wellbeing Considerations for Ecological Restoration in Puget Sound. Coastal Management, 44(5), 409-426. https://doi.org/10.1080/08920753.2016.1208037

Port Nicholson Block Trust (2012a). Port Nicholson Block Settlement Trust. Retrieved from https://www.pnbst.maori.nz/welcome-to-taranaki-whanui-ki-te-upoko-o-teika-port-nicholson-block-settlement-trust/

Port Nicholson Block Trust (2012b). Rohe. Retrieved from https://www.pnbst.maori.nz/about-us/rohe/ 
Raukura Consultants (2016). Cultural Impact Report: Prince of Wales Park Reservoir. Te Whanganui-a-Tara-Wellington, Aotearoa-New Zealand: Wellington Tenths Trust and Port Nicholson Block Settlement. Retrieved from: https://www.wellingtonwater.co.nz/dmsdocument/221

Robbins, P. (2012). Challenges in Social Constructivism. In P. Robbins (Eds.), Political Ecology: A Critical Introduction, Second Edition (pp. 122-143). Oxford, England: John Wiley \& Sons, Ltd.

Roberts, M., Norman, W., Minhinnick, N., Wihongi, D., and Kirkwood, C. (1995). Kaitiakitanga: Maori perspectives on conservation. Pacific Conservation Biology, 2(1), 7-20. https://doi.org/10.1071/PC950007

Rose, G. (1997). Situating knowledges: positionality, reflexivities and other tactics. Progress in Human Geography, 21(3), 305-320. https://doi.org/10.1191/030913297673302122

Schmidt, J. J. (2014). Historicising the Hydrosocial Cycle. Water Alternatives, 7(1), 220-234.

Smith, L. T. (1999). Decolonizing Methodologies: Research and Indigenous Peoples. London, England: Zed Books Ltd and Ōtepoti-Dunedin: University of Otago Press.

Stroh, M. (2000). Qualitative Interviewing. In D. Burton (Eds.), Research Training for Social Scientists (pp. 196-214). London, England: SAGE Publications. 
Sundberg, J. (2014). Decolonizing posthumanist geographies. Cultural Geographies, 21(1), 33-47. https://doi.org/10.1177/1474474013486067

Swyngedouw, E. (1996). The city as a hybrid: on nature, society and cyborg urbanisation. Capitalism, Nature, Socialism, 7(25), 65-80. https://doi.org/10.1080/10455759609358679

Swyngedouw, E. (2006). Circulations and metabolisms: (Hybrid) Natures and (Cyborg) Cities. Science as Culture, 15(2), 105-121. https://doi.org/10.1080/09505430600707970

Swyngedouw, E. (2009). The Political Economy and Political Ecology of the HydroSocial Cycle. Journal of Contemporary Water Research and Education, 142(1), 56-60. https://doi.org/10.1111/j.1936-704X.2009.00054.X

Swyngedouw, E. and Kaiika, M. (2002). The Environment of the City ... or the Urbanization of Nature. In G. Bridge and S. Watson (Eds.), A Companion to the City (pp. 567-580). Oxford, England: Blackwell Publishing.

Swyngedouw, E., Kaïka, M., and Castro, E. (2002). Urban Water: A Political-Ecology Perspective. Built Environment, 28(2), 124-137. DOI: 10.2307/23288796

Tenths Trust (n.d.). History. Retrieved from http://www.tekau.maori.nz/WellingtonTenthsTrust/AboutUs/History.aspx 
Tipa, G. (2009). Exploring Indigenous Understandings of River Dynamics and River Flows: A Case from New Zealand. Environmental Communication, 3(1), 95120. https://doi.org/10.1080/17524030802707818

Thomas, A. C. (2015). Indigenous more-than-humanisms: relational ethics with the Hurunui River in Aotearoa-New Zealand. Social \& Cultural Geography, 16(8), 974-990. https://doi.org/10.1080/14649365.2015.1042399

Thompson, L. (2014). Unearthing an Urban Stream. Radio New Zealand. Retrieved from

https://www.rnz.co.nz/national/programmes/ourchangingworld/audio/2595760/u nearthing-an-urban-stream

Todd, Z. (2014). Fish pluralities: Human-animal relations and sites of engagement in Paulatuuq, Arctic Canada. Études/Inuit/Studies, 38(1-2), 217-238. https://doi.org/10.7202/1028861ar

Todd, Z. (2016). An Indigenous Feminist's Take On The Ontological Turn: 'Ontology' Is Just Another Word for Colonialism. Journal of Historical Sociology, 29(1), 422. https://doi.org/10.1111/johs.12124

Tuck, E. and Yang, K. W. (2012). Decolonization is not a metaphor. Decolonization: Indigeneity, Education \& Society, 1(1), 1-40. 
Tuck, E. and Yang, K. (2014). R-Words: Refusing Research. In D. Paris and M. Winn (Eds.), Humanizing Research: Decolonizing Qualitative Inquiry with youth and Communities (pp. 223-247). Thousand Oakes, CA: Sage Publications.

Waitangi Tribunal (2003). Te Whanganui a Tara me ona Takiwa: Report on the Wellington District. Waitangi Tribunal Te Rōpū Whakamana i te Tiriti o Waitangi. Te Whanganui-a-Tara-Wellington, Aotearoa-New Zealand. Retrieved from

https://forms.justice.govt.nz/search/Documents/WT/wt_DOC_68452530/Wai14 $\underline{5 . p d f}$

Walsh, C. J., Roy, A., Feminella, J. W., Cottingham, P., Groffman, P. M., and Morgan II, R. P. (2005). The urban stream syndrome: current knowledge and the search for a cure. Journal of the North American Benthological Society, 24(3), 706-723. doi: 10.1899/0887-3593(2005)024\[0706:TUSSCK\]2.0.CO;2

Watts, V. (2013). Indigenous place-thought \& agency amongst humans and non-humans (First Woman and Sky Woman go on a European world tour!). Decolonization: Indigeneity, Education \& Society, 2(1), 20-34.

Wellington City Council (2013). Thematic Heritage Study of Wellington. Te Whanganui-a-Tara-Wellington, Aotearoa-New Zealand. Retrieved from https://wellington.govt.nz/ /media/services/community-andculture/heritage/files/thematic-heritage-study.pdf

Wellington City Council (2016). Wellington Town Belt overview map June 2016. Te Whanganui-a-Tara-Wellington, Aotearoa-New Zealand. Retrieved from 
https://wellington.govt.nz/ /media/recreation/parks-and-reserves/files/townbeltmapbook-june2016-web-overview.pdf?la=en

Wellington City Council (2019). Wellington Maps - Property - LocalMaps. Te Whanganui-a-Tara-Wellington, Aotearoa-New Zealand. Retrieved from https://gis.wcc.govt.nz/LocalMaps/Viewer/?map=57fb534c2174471ca48513211 $\underline{2088 \mathrm{afc}}$

Wesselink, A., Kooy, M., and Warner, J. (2017). Socio-hydrology and hydrosocial analysis: towards dialogues across disciplines. WIREs Water, 4(2), 1-14. https://doi.org/10.1002/wat2.1196

Wild, T. C., Bernet, J. F., Westling, E. L., and Lerner, D. N. (2011). Deculverting: reviewing the evidence on the 'daylighting' and restoration of culverted rivers. Water and Environment Journal, 25(3), 412-421. https://doi.org/10.1111/j.17476593.2010.00236.x

Woodford, D. and McIntosh, A. (2013) Science for Conservation 320: Effects of introduced trout predation on non-diadromous galaxiid fish populations across invaded riverscapes. Te Whanganui-a-Tara-Wellington, Aotearoa-New Zealand: Department of Conservation. Retrieved from https://www.doc.govt.nz/globalassets/documents/science-andtechnical/sfc320entire_print_quality.pdf

Wright, I. A., Davies, P. J., Findlay, S.J., and Jonasson, O. J. (2011). A new type of water pollution: concrete drainage infrastructure and geochemical contamination of urban waters. Marine and Freshwater Research, 62(12), 1355-1361. https://doi.org/10.1071/MF10296 
Yates, J. S., Harris, L. M., and Wilson, N. J. (2017). Multiple ontologies of water:

Politics, conflict and implications for governance. Environment and Planning D: Society and Space, 35(5), 797-815. https://doi.org/10.1177/0263775817700395

Z Energy (2013, April 5). Partnership leads to cultural landmark for Wellington. Scoop Independent News. Retrieved from

http://www.scoop.co.nz/stories/CU1304/S00119/partnership-leads-to-culturallandmark-for-wellington.htm 


\section{Appendices:}

Appendix A: Human Ethics Application Approval Appendix B: Animal Ethics Application Approval Appendix C: Information Sheet for Interviewees Appendix D: Consent Form for Interviewees Appendix E: Interview Schedule 


\section{Appendix A: Human Ethics Application}

\section{Approval:}

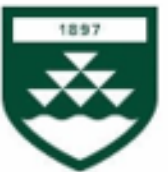

VICTORIA UNIVERSITY OF

WELLINGTON

TE HERENGA WAKA

Phone $\quad 0-4-4636028$

Email judith.loveridge@vuw.ac.nz

\begin{tabular}{l|l}
\hline TO & Sylvie Philippa Isabel McLean \\
\hline FROM & $\begin{array}{l}\text { Associate Professor Judith Loveridge, Convenor, Human Ethics } \\
\text { Committee }\end{array}$ \\
\hline DATE & 18 June 2019 \\
\hline PAGES & 1 \\
\hline & \multicolumn{2}{|l}{$\begin{array}{l}\text { Ethics Approval } \\
\text { Number: } 27544 \\
\text { Title: Using the hydrosocial cycle to discover the different } \\
\text { perceptions of water places along the Waimapihi Stream in Te } \\
\text { Whanganui-a-Tara Wellington City, Aotearoa New Zealand. }\end{array}$} \\
\hline
\end{tabular}

Thank you for your application for ethical approval, which has now been considered by the Human Ethics Committee.

Your application has been approved from the above date and this approval is valid for three years. If your data collection is not completed by this date you should apply to the Human Ethics Committee for an extension to this approval.

Best wishes with the research

Kind regards,

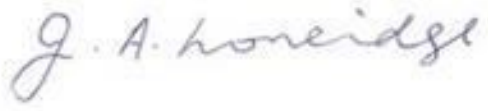

Judith Loveridge

Convenor, Victoria University of Wellington Human Ethics Committee 


\section{Appendix B: Animal Ethics Application Approval:}

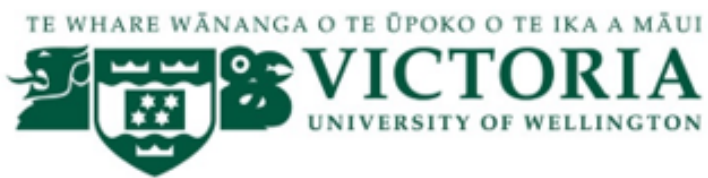

\section{VICTORIA UNIVERSITY OF WELLINGTON}

\section{ANIMAL ETHICS COMMITTEE}

June 17,2019

Memorandum to:

Dr Amanda Thomas

School of Geography, Environment and Earth Sciences

Re: Evaluation of AEC application:

27573 Using the hydrosocial cycle to discover the different perceptions of water places along the Waimapihi Stream

Your application to use live animals in your research at Victoria University of Wellington was approved by the AEC on June 14,2019. Approval was given for the requested period of 1 year and will expire on July 1,2020 .

We thank you for your cooperation in helping the Committee ensure appropriate animal welfare standards and procedures are in place at Victoria University.

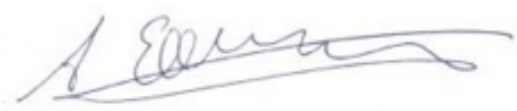

Bart Ellenbroek

AEC Chair

School of Psychology 


\section{Appendix C: Information Sheet for Interviewees:}

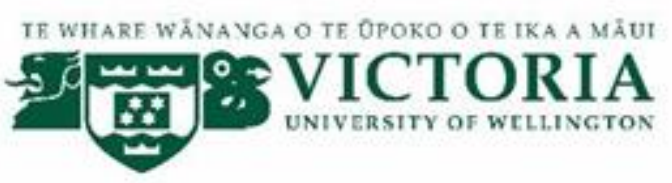

Stream or Discharge: Using the Hydrosocial Cycle to Explore the Meanings of the Waimapihi Stream in Te Whanganui-a-Tara Wellington, Aotearoa New Zealand.

\section{INFORMATION SHEET FOR PARTICIPANTS}

\section{Who am I?}

Kia ora, my name is Sylvie McLean and I am a Masters student in Environmental Studies at Victoria University of Wellington. This research project is work towards my thesis. I grew up in Te Aro and was a student at Te Aro Primary School. I want to carry out research in my community and on my main topic of interest, freshwater.

\section{What is the aim of the project?}

This project aims to explore the meanings and values held around the Waimapihi Stream in Te Whanganui-a-Tara Wellington City, both in the open upper reaches and the piped lower reaches, to help understand the different forms of urban streams and their place in the city. Your participation will support this research by providing unique perspectives of the Waimapihi Stream and the value you place in the ecosystem. Your participation will enable both you and me to learn more about our local stream. This research has been approved by the Victoria University of Wellington Human Ethics Committee [Reference \# 27544]. 


\section{How can you help?}

You have been invited to participate because your work means that you interact with the stream/you are an artist of a work exploring the stream/you live near the stream. If you agree to take part I will interview you in a café or another neutral place, we can decide together. The questions will centre on the Waimapihi Stream and your connections to it. The interview will take 30 minutes to an hour. The interview will be audio recorded, with your permission, to assist the write up of the transcript later on. You can choose not to answer any question or stop the interview at any time, without giving a reason. You can withdraw from the study by contacting me at any time before September $1^{\text {st }}$ 2019. If you withdraw, the information you provided will be destroyed or returned to you.

\section{What will happen to the information you give?}

This research is confidential. This means that the researcher named below will be aware of your identity, but the research data will be combined, and your identity will not be revealed in any reports, presentations, or public documentation. However, if you would like your identity revealed and your name to be used in reports then that is also an option.

Only my supervisors and I will read the notes or transcript of the interview. The interview transcripts, summaries and any recordings will be kept securely and destroyed on March 5 2020.

\section{What will the project produce?}

The information from my research will be used in my Masters thesis and academic publications. 


\section{If you accept this invitation, what are you rights as a research participant?}

You do not have to accept this invitation if you don't want to. If you decide to participate you have the right to:

- choose not to answer any question;

- ask for the recorder to be turned off at any time during the interview;

- withdraw from the study before 1st September 2019;

- $\quad$ ask any questions about the study at any time;

- receive a copy of your interview recording;

- receive a copy of your interview transcript;

- read over and comment on a written summary of your interview;

- be able to read any reports of this research by emailing the researcher to request a copy.

\section{If you have any questions or problems, who can you contact?}

If you have any questions, either now or in the future, please feel free to contact:

\section{Student:}

Sylvie McLean

sylviemclean@vuw.ac.nz

\section{Supervisor:}

Name: Amanda Thomas

Role: Lecturer

School: Geography, Environment and Earth Science

\section{Supervisor:}

Name: Mike Joy 
Role: Institute of Governance and Policy Studies Senior Researcher

School: Government

Phone: 044636881

\section{Human Ethics Committee information:}

If you have any concerns about the ethical conduct of the research, you may contact the Victoria University HEC Convenor: Dr Judith Loveridge. Email hec@vuw.ac.nz or telephone +64-4-463 6028 . 


\section{Appendix D: Consent Form for Interviewees:}

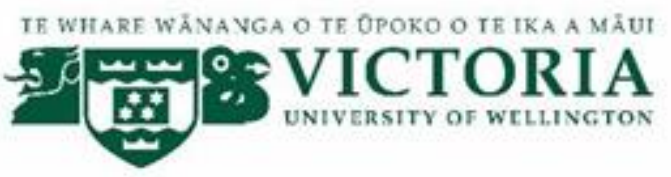

Stream or Discharge: Using the Hydrosocial Cycle to Explore the Meanings of the Waimapihi Stream in Te Whanganui-a-Tara Wellington, Aotearoa New Zealand.

\section{CONSENT TO INTERVIEW}

This consent form will be held for five years.

\section{Researcher: Sylvie McLean, School of Geography, Environment and Earth Science, Victoria University of Wellington.}

- I have read the Information Sheet and the project has been explained to me. My questions have been answered to my satisfaction. I understand that I can ask further questions at any time.

- I agree to take part in an audio recorded interview.

\section{I understand that:}

- I may withdraw from this study at any point before 1 st September 2019, and any information that I have provided will be returned to me or destroyed.

- The identifiable information I have provided will be destroyed on $5^{\text {th }}$ March 2020 .

- Any information I provide will be kept confidential to the researcher and the supervisor.

- I understand that the findings may be used for a Masters thesis and academic publications. 
- I understand that the recordings will be kept confidential to the researcher and the supervisor.

- I consent to information or opinions which I have given being attributed to me in any reports on this research: YES $\square$ $\mathrm{NO} \square$

- I would like a copy of the recording of my interview:

- I would like a copy of the transcript of my interview:

- I would like a summary of my interview:

- I would like to receive a copy of the final report and have added my email address below:

Signature of

participant:

Name of

participant:

Date:

Contact details: 


\section{Appendix E: Interview Schedule:}

\section{Interview Outline:}

- Tell me about yourself and your background:

- Do you know of the Waimapihi Stream? It is also known as Te Aro Stream. Can you please describe it for me?

- Have you been to the open section at the top of Holloway road? Tell me about the experience: How do you feel when you are there?

- Tell me about how do you feel about the piped section of the stream? Do you know where the piped path of the stream is?

- Tell me what you think about when you hear the term stormwater:

- Tell me about fish in the Waimapihi?

- Did you know that there are pieces of art along the stream that commemorate the stream? Tell me about your experience of them:

- Do you think art has a role in connecting people to the Waimapihi?

- Tell me about the place of the Waimapihi in the city?

- How would you like the stream to be in 10 years time, if there were no constraints or barriers so you could do whatever you like?

\section{Additional Question For Artists:}

- Tell me about your piece of art:

- Did you know about the Waimapihi before you made the art?

- What were your motivations and inspiration?

- Do you know about the other pieces of art along the piped section? 